\title{
Technology Advances in Phenol Removals: Current Progress and Future Perspectives
}

\author{
Wibawa Hendra Saputera $1,2,3, * \mathbb{C}$, Amellia Setyani Putrie ${ }^{1}$, Ali Asghar Esmailpour ${ }^{4}$, Dwiwahju Sasongko ${ }^{1,3}$, \\ Veinardi Suendo ${ }^{5,6} \mathbb{D}$ and Rino R. Mukti ${ }^{2,5,6}$
}

1 Research Group on Energy and Chemical Engineering Processing System, Department of Chemical Engineering, Faculty of Industrial Technology, Institut Teknologi Bandung, Jl. Ganesha No. 10, Bandung 40132, Indonesia; amelliasputrie@gmail.com (A.S.P.); sasongko@che.itb.ac.id (D.S.)

2 Center for Catalysis and Reaction Engineering, Institut Teknologi Bandung, Jl. Ganesha No. 10, Bandung 40132, Indonesia; rino@chem.itb.ac.id

3 Research Center for New and Renewable Energy, Institut Teknologi Bandung, Jl. Ganesha No. 10, Bandung 40132, Indonesia

4 Particles and Catalysis Research Group, School of Chemical Engineering, Faculty of Engineering, The University of New South Wales, Kensington, NSW 2052, Australia; a.esmailpourvalmazouyi@unsw.edu.au

5 Division of Inorganic and Physical Chemistry, Faculty of Mathematics and Natural Sciences, Institut Teknologi Bandung, Jl. Ganesha No. 10, Bandung 40132, Indonesia; vsuendo@chem.itb.ac.id

6 Research Center for Nanoscience and Nanotechnology, Institut Teknologi Bandung, Jl. Ganesha No. 10, Bandung 40132, Indonesia

* Correspondence: hendra@che.itb.ac.id; Tel.: +62-821-1768-6235

Citation: Saputera, W.H.; Putrie, A.S.; Esmailpour, A.A.; Sasongko, D.; Suendo, V.; Mukti, R.R. Technology Advances in Phenol Removals: Current Progress and Future Perspectives. Catalysts 2021, 11, 998. https: / /doi.org/10.3390/ catal11080998

Academic Editors: Andres Aguayo and Eva Bejerano

Received: 22 July 2021

Accepted: 16 August 2021

Published: 19 August 2021

Publisher's Note: MDPI stays neutral with regard to jurisdictional claims in published maps and institutional affiliations.

Copyright: (C) 2021 by the authors Licensee MDPI, Basel, Switzerland. This article is an open access article distributed under the terms and conditions of the Creative Commons Attribution (CC BY) license (https:/ / creativecommons.org/licenses/by/ $4.0 /)$.

\begin{abstract}
Phenol acts as a pollutant even at very low concentrations in water. It is classified as one of the main priority pollutants that need to be treated before being discharged into the environment. If phenolic-based compounds are discharged into the environment without any treatments, they pose serious health risks to humans, animals, and aquatic systems. This review emphasizes the development of advanced technologies for phenol removal. Several technologies have been developed to remove phenol to prevent environmental pollution, such as biological treatment, conventional technologies, and advanced technologies. Among these technologies, heterogeneous catalytic ozonation has received great attention as an effective, environmentally friendly, and sustainable process for the degradation of phenolic-based compounds, which can overcome some of the disadvantages of other technologies. Recently, zeolites have been widely used as one of the most promising catalysts in the heterogeneous catalytic ozonation process to degrade phenol and its derivatives because they provide a large specific surface area, high active site density, and excellent shape-selective properties as a catalyst. Rational design of zeolite-based catalysts with various synthesis methods and pre-defined physiochemical properties including framework, ratio of silica to alumina $\left(\mathrm{SiO}_{2} / \mathrm{Al}_{2} \mathrm{O}_{3}\right)$, specific surface area, size, and porosity, must be considered to understand the reaction mechanism of phenol removal. Ultimately, recommendations for future research related to the application of catalytic ozonation technology using a zeolite-based catalyst for phenol removal are also described.
\end{abstract}

Keywords: phenol removal; technology advances; catalytic ozonation; zeolite

\section{Introduction}

At present, about $80 \%$ of all wastewater is discharged into the world's waterways, wherein it creates health, environmental, and climate-associated hazards [1]. Phenol and phenolic compounds are found in several industrial wastewater processes such as refineries, coking operations, coal processing, petrochemicals, pulp, paper, etc., as shown in Figure 1. In addition, phenolic-based compounds (cresols, xylenols, etc.) are also found in wastewater of biomass gasification plants due to the formation of tar (a group of organic 
compounds) in the process, especially if wet scrubbers are an effective method of removing tar from the syngas stream [2].

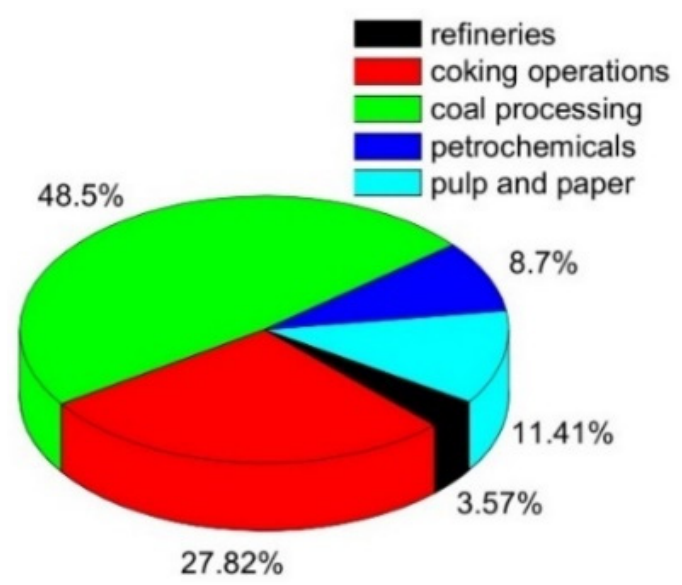

Figure 1. Phenol concentration (\%) in the effluent of various industries. Reproduced from ref. [3]. Copyright 2019 Elsevier.

Due to its high toxicity and poor biodegradability, phenol acts as a pollutant even in very low concentrations. According to the United States Environmental Protection Agency (USEPA) and the National Pollutant Release Inventory (NPRI) of Canada, phenol is classified as one of 129 priority pollutants [4-7]. It is toxic, carcinogenic, mutagenic, teratogenic, and when the concentration in wastewater is higher than $50 \mathrm{mg} / \mathrm{L}$, it can inhibit the rate of biodegradation [7,8]. As a result, if phenolic compounds are discharged into the environment without any treatment, they can cause serious health risks to humans, animals, and aquatic systems. It can cause irregular breathing, muscle weakness, tremors, coma, and breathing cessation at lethal doses in humans with prolonged exposure. The level of toxicity of phenol for humans varies between 10 to $24 \mathrm{mg} / \mathrm{L}$, and the lethal blood concentration is approximately $1.5 \mathrm{mg} / \mathrm{mL}$ [8]. In addition, exposure to phenolic compounds can cause eating disorders, weight loss, diarrhea, vertigo, salivation, and dark stools, as well as irritation of the ducts and the central nervous systems and liver, kidneys, and vascular tissues in animals. Therefore, phenol compounds must be removed from wastewater before being discharged into the environment to meet the maximum allowable phenol limit in wastewater stream, which is less than $1 \mathrm{mg} / \mathrm{L}(1 \mathrm{ppm})$. The levels of phenol concentration in some industrial wastewaters are shown in Table 1.

Table 1. The reported levels of phenol in industrial wastewater. Adapted from ref. [9]. Copyright 2006 Elsevier.

\begin{tabular}{lc}
\hline \multicolumn{1}{c}{ Industrial Sources } & Phenol Concentration (mg/L) \\
\hline Paint manufacturing & 1.1 \\
Rubber industry & $3-10$ \\
Leather & $4.4-5.5$ \\
Ferrous industry & $5.6-9.1$ \\
Pulp and paper industry & 22 \\
Petroleum refineries & $40-185$ \\
Fiberglass manufacturing & $40-2564$ \\
Wood preserving industry & $50-953$ \\
Textile & $100-150$ \\
Petrochemical & $200-1220$ \\
Coke ovens (without dephenolization) & $600-3900$ \\
Phenolic resin & $1270-1345$ \\
Phenolic resin production & 1600 \\
Coal conversion & $1700-7000$ \\
Biomass-based gasification & $772-4630$ \\
\hline
\end{tabular}


Various treatment techniques have been applied to remove phenol and phenolic compounds from aqueous effluent, including biological treatment, conventional treatments, and advanced treatments. Figure 2 shows the number of publications related to various conventional and advanced technologies for phenol removal. This review article provides a comprehensive summary of effective and potential methods for removing phenol from wastewater.

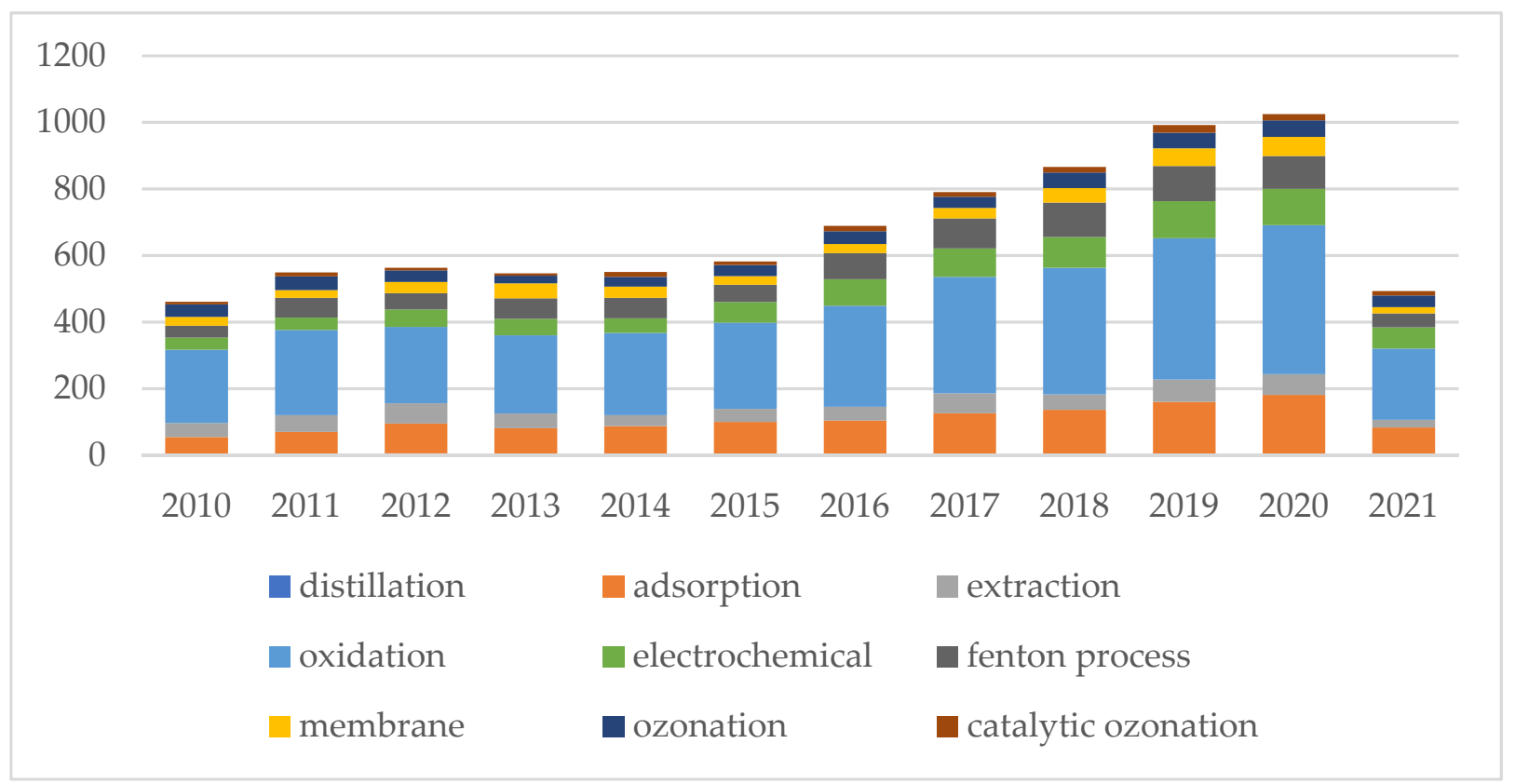

Figure 2. The number of annual publications related to various methods to degrade phenol in 2010-2021. Indexed by Scopus (TITLE-ABS-KEY (terms); terms: distillation, adsorption, extraction, oxidation, electrochemical, Fenton process, membrane, ozonation, catalytic ozonation phenol degradation) [10].

\section{Phenol Compounds in Wastewater}

Wastewater is polluted water that contains physical, chemical, and biological pollutants caused by human use and has a negative impact on the environment. Domestic wastewater from households, municipal wastewater from communities, and industrial wastewater are some types of wastewaters that are all around us. Phenol is an important organic chemical intermediate and raw material in wastewater. The main application of phenol is in the production of phenolic resin, bisphenol A, and caprolactam [11]. Due to its high harmful effect, phenol is classified as a pollutant even at very low concentrations. It can be found in several wastewater treatment industries, such as oil refining, petrochemicals, and pharmaceuticals industries.

\subsection{Chemical Structure and Properties of Phenol}

Several types of phenolic compounds in nature, such as eugenol, thymol, pyrogallol, guaiacol, or pyrocatechol, occur naturally. However, some are formed as byproducts of industrial, agricultural, and human activities that can pose serious environmental risks. Phenol with a chemical structure of $\mathrm{C}_{6} \mathrm{H}_{5} \mathrm{OH}$ represents an aromatic compound with one or more hydroxyl groups $(-\mathrm{OH})$ connected directly to an aromatic system (e.g., phenyl, naphthyl). Moreover, all the carbon atoms that make up aromatic rings are $\mathrm{sp}^{2}$ hybridized. Therefore, phenyl has a hexagonal planar structure with all bond angles of $120^{\circ}$ and delocalized electrons distributed over the ring. Thus, $\mathrm{Csp}^{2}-\mathrm{Osp}^{3}$ forms $\mathrm{C}-\mathrm{O}$ and $\mathrm{O}-\mathrm{H}$ bonds made from $\mathrm{Osp}^{3}-\mathrm{H} 1 \mathrm{~s}$, and unattached electron pairs occupy the other two oxygen atomic orbitals. As shown in Figure 3 the hydroxyl functional group of $\mathrm{C}-\mathrm{O}-\mathrm{H}$ has a bent shape that is close to a tetrahedral bond perspective with a bond angle of $109.5^{\circ}$. Both $\mathrm{C}-\mathrm{O}$ and $\mathrm{O}-\mathrm{H}$ are polar because oxygen is more electronegative than carbon and hydrogen [12]. 


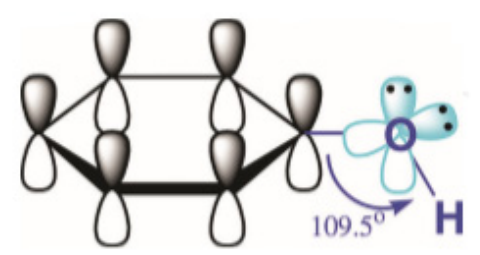

Figure 3. The chemical structure of phenol. Reproduced from Ref. [12]. Copyright 2017 IntechOpen.

Phenol has a cross-sectional area of $4.20 \times 10^{-10} \mathrm{~m}$, a volume of $87.8 \times 10^{-6} \mathrm{~m}^{3} / \mathrm{mol}$, a saturated concentration in water of $912 \mathrm{~mol} / \mathrm{m}^{3}$, and pKa of 9.99 [13]. Phenol is classified as an acid that is weaker than carbonic acid (pKa of carbonic acid is 6.4) but stronger than water ( $\mathrm{pKa}$ of water is 15.7). Substituted phenol derivatives do not dissolve well in water (solubility does not exceed $30 \mathrm{~g} / \mathrm{L}$ ), but unsubstituted phenols are relatively soluble in water $(83 \mathrm{~g} / \mathrm{L})$. Alkyl and halogen groups can be used as substituents to increase the hydrophobicity of the aromatic ring (decrease its solubility in water). Adsorption or extraction of phenolic compounds is challenging at very low concentrations because phenols have a large variety of physicochemical properties, especially the electron density of the aromatic ring that affects the solubility of phenol compounds in water [13]. The physiochemical properties of phenol are shown in Table 2.

Table 2. Chemical and physical properties of phenol. Adapted from ref. [14]. Copyright 2015 Taylor \& Francis Online.

\begin{tabular}{|c|c|c|}
\hline Properties & Value & Units \\
\hline Reactivity & 0 (normally stable) & - \\
\hline Flammability & 2 & - \\
\hline Health & 4 (serious temporary or residual injury) & - \\
\hline Special COR & Corrosive & - \\
\hline Molecular weight & 94.11 & $\mathrm{~g} / \mathrm{mol}$ \\
\hline $\mathrm{T}_{\text {melting }}$ & 40.91 & ${ }^{\circ} \mathrm{C}$ \\
\hline $\mathrm{T}_{\text {boiling }}$ & 181.75 & ${ }^{\circ} \mathrm{C}$ \\
\hline Density & 1.07 & $\mathrm{~g} / \mathrm{cm}^{3}$ \\
\hline Flash point & 79 & ${ }^{\circ} \mathrm{C}$ \\
\hline Acidity in water (pKa) & 9.89 & - \\
\hline Water solubility (at $20^{\circ} \mathrm{C}$ ) & 8.3 & g phenol/100 $\mathrm{mL} \mathrm{H}_{2} \mathrm{O}$ (wt.\%) \\
\hline Water solubility (at $25^{\circ} \mathrm{C}$ ) & 8 & g phenol/100 $\mathrm{mL} \mathrm{H}_{2} \mathrm{O}$ (wt.\%) \\
\hline Vapor pressure (at $25^{\circ} \mathrm{C}$ ) & 0.35 & $\mathrm{mmHg}$ \\
\hline
\end{tabular}

\subsection{Phenol Toxicity}

Phenol is one of the top priority contaminants and also a potentially carcinogenic pollutant [13]. Phenol is a toxic, carcinogenic, mutagenic, and teratogenic substance that can inhibit the rate of biodegradation at concentrations of more than $50 \mathrm{mg} / \mathrm{L}$ in wastewater [7]. For human and aquatic life, the levels of toxicity vary between 9 and $25 \mathrm{mg} / \mathrm{L}$. Exposure to phenolic compounds can cause eating disorders, weight loss, diarrhea, vertigo, salivation, and dark coloration of feces [15]. According to the Health Protection Agency (HPA), there is about $60-88 \%$ of phenol exposure through inhalation and followed by oral and dermal exposure [16]. The toxicological properties of phenol have been contributed mainly by the formation of organic species and free radical species and their hydrophobicity. The structure of phenol itself shows its reactivity, which leads to its properties such as persistence in the environment, toxicity, and possible carcinogenicity to living organisms [17]. The presence of phenol in wastewater during disinfection and oxidation processes can also form substituted compounds and toxic intermediates as secondary pollutants that can inhibit microorganisms in biological treatment processes [14]. Therefore, the removal and mineralization of phenolic compounds from wastewater is necessary before being discharged into the environment. Consequently, wastewater treatment with phenol species has attracted a lot of attention due to the toxicity and low biodegradability of phenolic compounds. 


\section{Development of Technologies for Phenol Treatment}

Various types of processes have been investigated to remove phenol content from wastewater. These processes can be classified into three types: biological treatment, conventional technologies (such as distillation, adsorption, and extraction), and advanced technologies (such as chemical oxidation, Fenton process, electrochemical oxidation, membrane processes ozonation, and catalytic ozonation). In addition to the main technical considerations, environmental and economic control aspects should also be considered to select appropriate, sustainable, and environmentally friendly technologies [18].

\subsection{Biological Treatments}

Biological wastewater treatment is a useful process in which processes are utilized to decompose organic substances. Biological treatments generally rely on bacteria, nematodes, or other small organisms to break down organic wastes using normal cellular processes. Due to the ease of use of biological treatment systems, it is commonly used as a comparison with other phenol processing technologies. Although biological treatment provides environmentally friendly and energy-efficient technology compared to physiochemical treatment, the presence of toxic or bio recalcitrant pollutants in the treated water can inhibit biological reactions and is not feasible for high phenol concentrations $[7,15]$. It has been reported by Marrot et al. [19] that the biological treatment of phenol removal was economical and practical at a low concentration of phenol. However, phenol or its derivatives can also cause deflocculation, resulting in settling problems in the clarifier. Thus, in order to achieve satisfactory phenol removal efficiency, the phenol concentration needs to be kept below the threshold of $420 \mathrm{mg} / \mathrm{L}$ [20], and acclimatization of microorganisms to wastewater must be fulfilled [20].

In a typical biological process, microorganisms degrade phenol into other non-toxic compounds. The aerobic biodegradation by activated sludge is the most commonly used method to degrade phenol. The activated sludge process can be defined as a system of activated biomass that is recirculated, and the oxidation of organic content occurs in the presence of oxygen. Activated sludge generally consists of microorganisms, inanimate organic matter, and inorganic compounds. Activated sludge has been successfully applied for phenol degradation using a batch reactor up to $1500 \mathrm{mg} / \mathrm{L}$ at $\mathrm{pH} 6[20,21]$. It has been reported that acclimatized active biomass degrades phenolic compounds more effectively than pure strains one or more orders of magnitude faster. The ability of active biomass to degrade pollutants is also influenced by natural carbon sources. In general, focusing on various concentrations of nutrients such as glucose, yeast, and ammonium sulfate can increase the ability to degrade phenols. Furthermore, phenol biodegradation increases at higher concentrations of inorganic nutrients.

Biological techniques can be combined with enzymatic treatment to remove phenolic compounds [19]. Bevilaqua et al. revealed that phenol could be degraded even at a concentration of $420 \mathrm{mg} / \mathrm{L}$ by using an integration of enzymatic treatment and aerobic biological process [22]. Another effective process in biological treatment is sequencing batch reactor (SBR), a variation of the activated sludge process. This process takes place in a batch system where all phases of the biological process occur in one tank. The SBR system consists of two or more reactor tanks that are operated in parallel. First, the influent stream goes through a screening process before entering the SBR. Then, the waste is processed in a series of batch phases in SBR to achieve the desired effluent concentration. Then, the discharged sludge from SBR flows into the treatment unit. Finally, the SBR output (liquid) flows into the disinfection tank, and the resulting treated water is free of pollutant compounds. In an SBR cycle, there are usually five phases, including fill, react, settle, decant, and idle (Figure 4). The duration of each phase is controlled by a programmable logic controller (PLC). In the fill phase, wastewater enters the tank, mixing with the biomass from the previous cycle. Some aeration may occur during this phase. Then the aeration process is carried out in the reaction phase so as to allow oxidation and nitrification to occur. During the settling phase, aeration and mixing are suspended, and the stationary 
solids settle. The treated wastewater is then discharged from the tub in the decantation phase. In the last phase (idle), the pool cannot operate because it is waiting for the start of the next cycle. Meanwhile, some solids are removed from the tub and discharged as sewage sludge. The average time to complete the process in the sequencing batch reactor is approximately $16-36 \mathrm{~h} \mathrm{[23].}$

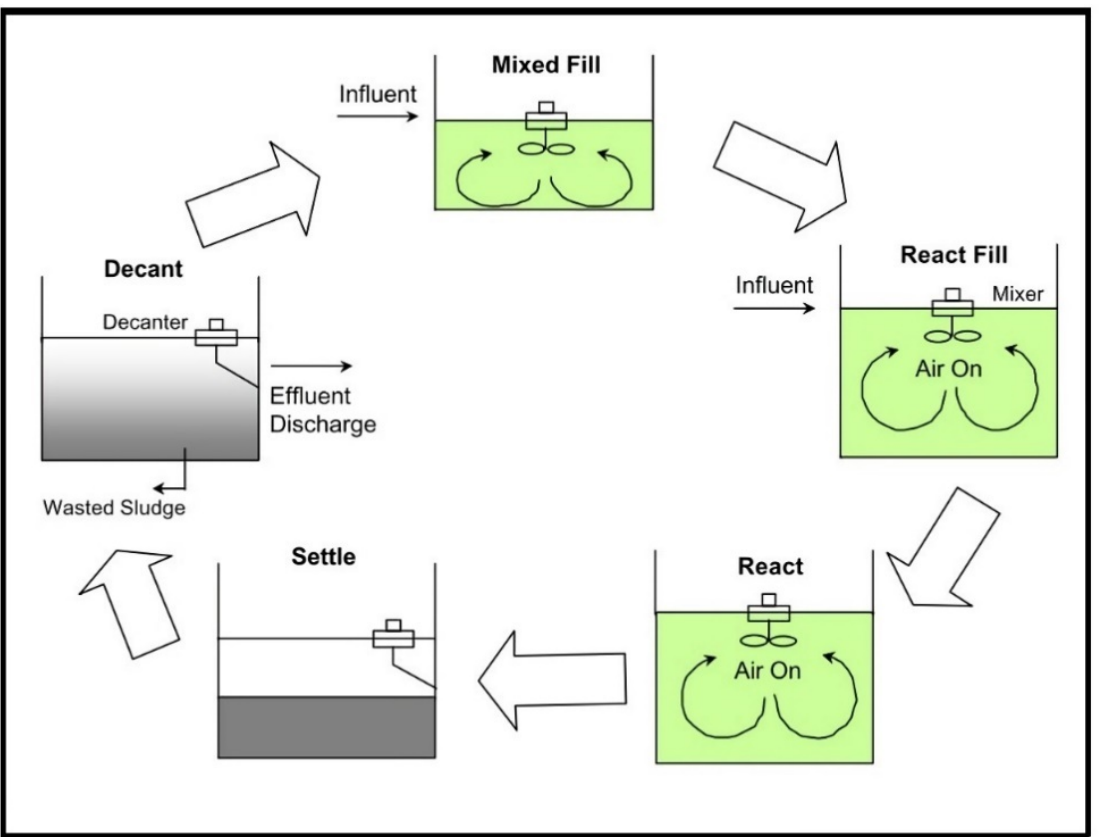

Figure 4. Schematic of the sequencing batch reactor (SBR) processing cycle. Adapted from Ref. [23].

\subsection{Conventional Technologies}

\subsubsection{Steam Distillation}

Steam distillation is a method of separating two immiscible liquids based on the volatility of the steam. In the liquid phase, phenol has limited miscibility with water (close to $10-70 \%(w / w)$ phenol approaches the limit at room temperature), but this immiscibility completely disappears at temperatures above $68^{\circ} \mathrm{C}$. The phenol-water solution has a minimum azeotrope, at $9.21 \%$ phenol ( $w / w)$, according to a molar fraction of 0.019 , at temperature and pressure of $94.5^{\circ} \mathrm{C}$ and $1 \mathrm{~atm}$, respectively. Based on the relative volatility of phenol, steam or azeotropic distillation can separate phenolic contaminants from wastewater [14,15,24,25] (Figure 5).

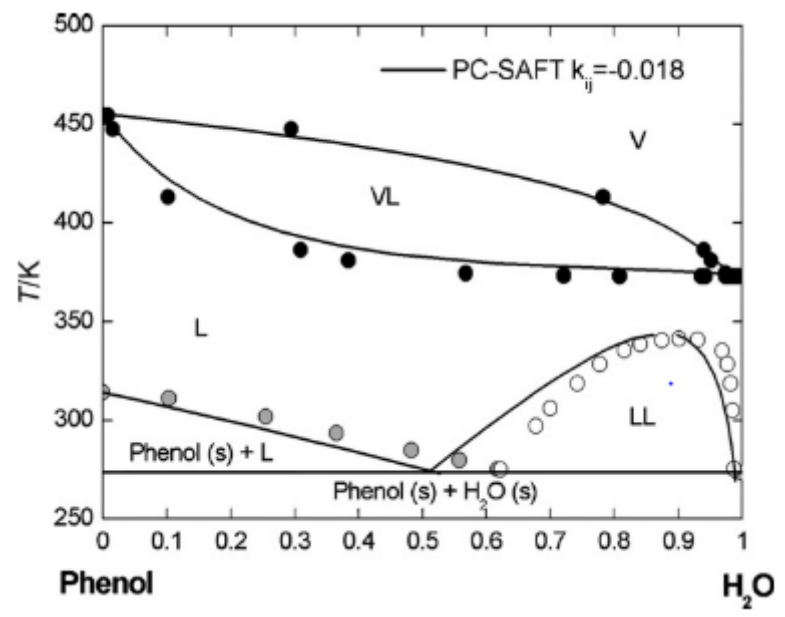

Figure 5. Phase diagram showing vapor-liquid, liquid-liquid, solid-liquid, and solid-liquid-liquid equilibria of phenol-water system. Reproduced from Ref. [26]. Copyright 2007 Elsevier. 
In general, the removal of phenolic compounds from wastewater using steam distillation can be illustrated in Figure 6a. Wastewater enters the distillation column, operating at $1 \mathrm{~atm}$. The temperature around the boiling point of water, the rich water evaporates to the top of the column and then condenses into clean wastewater while rich phenol comes out from the bottom of the column. The steam distillation method is not suitable for wastewater with low phenol concentration due to the high energy costs. There are few data on steam distillation to remove phenol from wastewater because it is used for high concentration phenol solutions (more than $3000 \mathrm{mg} / \mathrm{L}$ ), which are not very common in wastewater treatment processes [14].

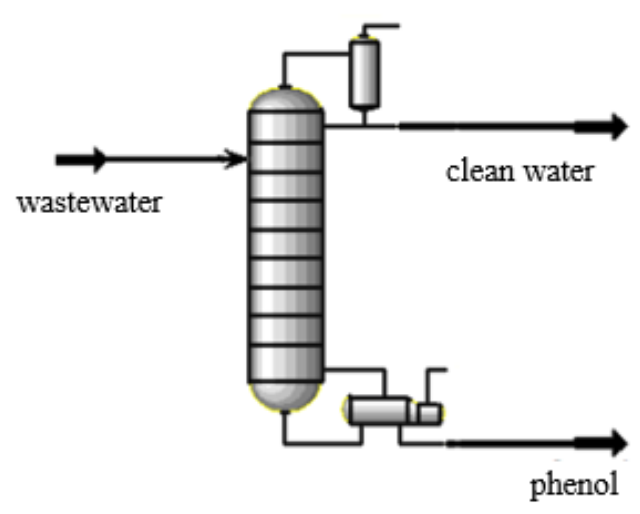

(a)

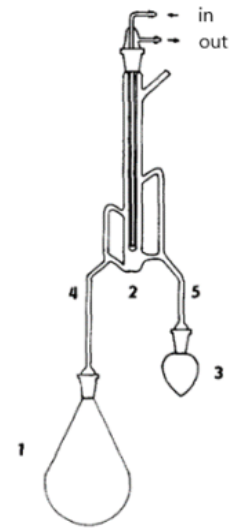

(b)

Figure 6. Schematic of (a) distillation column, (b) micro-apparatus for continuous steam distillationextraction Adapted from Ref. [27]. Copyright 1984 Elsevier.

A simultaneous distillation-extraction process has been developed to purify wastewater from phenol contaminants. Figure $6 \mathrm{~b}$ shows a continuous steam distillation-continuous liquid-liquid extraction scheme using diethyl ether as the extraction solvent, which has a very low boiling point. In this case, the vapor pressure of the sample compounds can be as little as possible above the extraction solvent. As shown in Figure 6b, the phenol-containing wastewater is distilled from flask 1 , and the extraction solvent is distilled from flask 3 . The cold finger condenses the vapors. The organic compounds (phenols) are extracted from the condensate using a continuous supply of extraction solvent. Then, the aqueous and the organic phase are separated at the bottom of the central part of apparatus 2 and returned through their return arms 4 and 5 to flasks 1 and 3 [27]. The comparison of the efficiency of phenol removal from water with the distillation process is shown in Table 3.

Table 3. Comparison of phenol recovery using distillation-based process.

\begin{tabular}{|c|c|c|c|c|}
\hline Technique & Operating Conditions & Additional Chemical & Recovery of Phenol & Ref. \\
\hline $\begin{array}{l}\text { Steam distillation using } \\
\text { ultraviolet spectrometry }\end{array}$ & $\begin{array}{l}\mathrm{pH} \leq 4 \\
\lambda_{\max }: 271 \mathrm{~nm}\end{array}$ & - & $95.3 \%$ & [28] \\
\hline Steam distillation & $\mathrm{C}_{\text {phenol }}: 0.4 \mathrm{mg} / \mathrm{L}$ & Sodium chloride & $100.0 \%$ & [29] \\
\hline Distillation-extraction & $\begin{array}{l}\text { Extractant: diethyl ether } \\
\mathrm{C}_{\text {phenol }}: 26 \mathrm{mg} / \mathrm{L} \\
\mathrm{t}: 1.5 \mathrm{~h} \\
\mathrm{pH}: 1 \\
\mathrm{~T}_{\text {oil bath }}: 130^{\circ} \mathrm{C} \\
\mathrm{T}_{\text {water bath }}: 55^{\circ} \mathrm{C}\end{array}$ & Sodium chloride & $91.1 \%$ & [27] \\
\hline Distillation-extraction & $\begin{array}{l}\text { Extractant: diethyl ether } \\
\mathrm{t}: 1.5 \mathrm{~h} \\
\mathrm{~T}_{\text {oil bath }}: 160{ }^{\circ} \mathrm{C} \\
\mathrm{T}_{\text {water bath }}: 50^{\circ} \mathrm{C}\end{array}$ & Sodium chloride & $91.8 \%$ & [30] \\
\hline
\end{tabular}

Notes: $\mathrm{t}=$ time, $\mathrm{T}=$ temperature, $\mathrm{C}_{\text {phenol }}=$ initial phenol concentration, $\lambda_{\max }=$ maximum wavelength. 


\subsubsection{Adsorption}

Adsorption is a surface phenomenon and can be defined by increasing the concentration of a particular component at the surface or interface between two phases (Figure 7). Several factors affecting the adsorption process are temperature, nature of adsorbates and adsorbents, presence of other pollutants, and other operating conditions such as $\mathrm{pH}$, temperature, pollutants concentration, contact time, and adsorbent particle size [31]. Adsorption methods are widely used in wastewater purification from organic and inorganic pollutants without producing harmful by-products [24,32]. The adsorption process is effective in reducing the concentration of phenol in the water. However, economic factors (including energy) of using and recycling required secondary materials, adsorbents, or extractants also need to be considered [33]. The main advantages of the adsorption process to remove phenolic pollutants are that it is a very effective process, flexibility and simplicity of design, ease of operation, and it does not produce harmful by-products [34]. On the other hand, the main drawbacks of the adsorption technology are that it requires a large amount of adsorbent, the high cost of adsorbent, and it is very difficult to separate adsorbent from adsorbates [35].

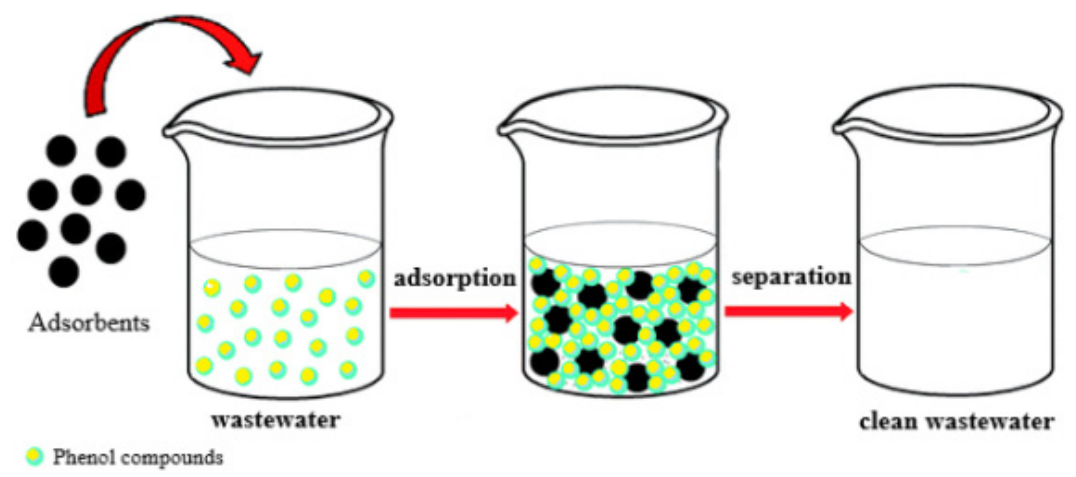

Figure 7. Schematic of phenol removal from wastewater in batch system adsorption.

Activated carbon is the most commonly used adsorbent for phenol removal from water in the adsorption process, but its low stability and the difficulty to regenerate it are the main drawbacks $[15,24,32,36]$. The adsorption capacity of activated carbon in the liquid-phase adsorptions for aromatic compounds (phenols) depends on several factors including the physical properties of the adsorbent (pore structure, ash content, and functional groups) and also depends on its precursor material and preparation method, the properties of the adsorbate (solubility, pKa, functional groups, polarity, molecular weight, and size) and solution conditions $(\mathrm{pH}$, ionic strength, adsorbate concentration, and oxygen availability) [24].

Ma et al. [37] studied the batch adsorption of phenol using powdered activated carbon (PAC) as an adsorbent. They investigated the effect of carbon type, carbon loading, initial $\mathrm{pH}$ solution, temperature, and pre-oxidation. The results showed that phenol removal using PAC bamboo charcoal had the most effective adsorbent. It has the largest specific surface area among the prepared catalysts such as coconut shell charcoal and coal charcoal. The phenol adsorption significantly increased more than $80 \%$ of PAC adsorption capacity within 10 min under identical condition (PAC loading $=20 \mathrm{mgL}^{-1}$, initial phenol concentration $=1000 \mu \mathrm{gL}^{-1}$, temperature $=25^{\circ} \mathrm{C}$ ). Increasing the PAC loading also increases the removal of phenol from the water due to an increase in the surface area of the adsorbent and the availability of more vacant surface sites. The pKa value of phenol is 9.9 , and the $\mathrm{pH}$ of the zero-point charge of the PAC is about 6.2, and results showed that $\mathrm{pH} 9$ is the optimum $\mathrm{pH}$ for phenol removal. Phenol removal decreased with increasing solution temperature from $15{ }^{\circ} \mathrm{C}$ to $35^{\circ} \mathrm{C}$. Further thermodynamic study must be carried out to clarify the effect of temperature on phenol adsorption. Another study by Mandal and Das [38] assessed the efficiency of phenol removal from wastewater using sludge produced from basic oxygen furnaces in steel mills as an adsorbent. The maximum phenol removal 
achieved was about $63 \%$ with the adsorbent loading of $20 \mathrm{~g} / \mathrm{L}$, initial phenol concentration of $10 \mathrm{mg} / \mathrm{L}, \mathrm{pH} 7$, adsorption time of $240 \mathrm{~min}$, and temperature of $35^{\circ} \mathrm{C}$.

A recent study by Catizzone et al. [39] investigated wastewater purification using a biomass-derived syngas scrubber containing phenol using biochar and activated carbons. This experiment used phenol solution as the model solution. Two activated carbons (SP800 and SP1000) and two biochar obtained during the pyrolysis (SPBCP) and gasification (SPBCG) processes were used as adsorbers. Both batch and continuous test data were obtained for the comparison of reaction kinetics. However, to investigate the efficiency of the absorber in purification, the batch condition is easier to analyze. The best carbons among the adsorbents used in this experiment were SP1000 and SPBCG. For SPBCG, the phenol removal was about $64 \%$ and the wastewater purification rate was about $25 \%$. For SP1000, the phenol removal was about $96 \%$ and the wastewater purification rate was about $92 \%$ with an initial phenol concentration of $5 \mathrm{~g} / \mathrm{L}$ and at a temperature of $25^{\circ} \mathrm{C}$.

The comparison of removal efficiency using various adsorbents for phenol removal is summarized in Table 4.

Table 4. The effectiveness comparison of various adsorbents for removing phenolic-based compounds in the solution.

\begin{tabular}{|c|c|c|c|c|c|}
\hline No & Adsorbent & Phenolic Compound & Operating Conditions & Efficiency of Removal & Ref. \\
\hline 1 & $\begin{array}{l}\text { Activated carbon from } \\
\text { Lantana camara }\end{array}$ & Phenol & $\begin{array}{l}\mathrm{C}_{\text {adsorbent }}: 1 \mathrm{gL}^{-1} \\
\mathrm{C}_{\text {phenol }}: 150 \mathrm{mgL}^{-1} \\
\text { pH: } 8.5 ; \mathrm{T}: 25^{\circ} \mathrm{C} \\
\text { t: } 7 \mathrm{~h}\end{array}$ & $91.1 \%$ & [40] \\
\hline 2 & \multirow{2}{*}{$\begin{array}{l}\text { Chicken manure biochar } \\
\text { (CBC) }\end{array}$} & Phenol & $\begin{array}{l}\mathrm{C}_{\text {adsorbent }}: 0.3 \mathrm{gL}^{-1} \\
\mathrm{C}_{\text {phenol }}: 87.2 \mathrm{mgL}^{-1} \\
\text { pH: } 9.98 ; \mathrm{T}: 22^{\circ} \mathrm{C} \\
\text { t: } 90 \text { min }\end{array}$ & $78.5 \%$ & [32] \\
\hline 3 & & 2,4-dinitrophenol & $\begin{array}{l}\mathrm{C}_{\text {adsorbent }}: 0.3 \mathrm{gL}^{-1} \\
\mathrm{C}_{\text {phenol }}: 108.1 \mathrm{mgL}^{-1} \\
\text { pH: } 5.37 ; \mathrm{T}: 22^{\circ} \mathrm{C} \\
\text { t: } 90 \mathrm{~min}\end{array}$ & $83.4 \%$ & [32] \\
\hline 4 & $\begin{array}{l}\text { Clarified sludge from basic } \\
\text { oxygen furnace }\end{array}$ & Phenol & $\begin{array}{l}\mathrm{C}_{\text {adsorbent }}: 20 \mathrm{gL}^{-1} \\
\mathrm{C}_{\text {phenol }}: 10 \mathrm{mgL}^{-1} \\
\text { pH: } 7.00 ; \mathrm{T}: 35^{\circ} \mathrm{C} \\
\text { t: } 240 \mathrm{~min}\end{array}$ & $63.0 \%$ & [38] \\
\hline 5 & Fe-nano zeolite (Fe-Nz) & $\begin{array}{l}\text { Phenol, 2-chlorophenol, } \\
\text { 2-nitrophenol }\end{array}$ & $\begin{array}{l}\mathrm{C}_{\text {adsorbent }}: 2.5 \mathrm{gL}^{-1} \\
\mathrm{C}_{\text {phenol }}: 1000 \mathrm{mgL}^{-1} \\
\text { pH: } 5.00 ; \mathrm{T}: 20^{\circ} \mathrm{C} \\
\text { t: } 230 \mathrm{~min}\end{array}$ & $\begin{array}{c}\text { Phenol: } 86.4 \% \\
\text { 2-chlorophenol: } 89.8 \% \\
\text { 2-nitrophenol: } 97.2 \%\end{array}$ & [41] \\
\hline 6 & Hybrid (CNT/PEG) & Phenol & $\begin{array}{l}\mathrm{C}_{\text {adsorbent }}: 20 \mathrm{mgL} \\
\mathrm{C}_{\text {phenol }}: 20 \mathrm{ppm} \\
\text { pH: } 7.00 ; \mathrm{T}: 25^{\circ} \mathrm{C} \\
\text { t: } 20 \mathrm{~min}\end{array}$ & $97.0 \%$ & [42] \\
\hline 7 & PAC & Phenol & $\begin{array}{l}\mathrm{C}_{\text {adsorbent }}: 20 \mathrm{mgL}^{-1} \\
\mathrm{C}_{\text {phenol }}: 1000 \mu \mathrm{gL}^{-1} \\
\text { no pH adjustment; } \mathrm{T}: 25^{\circ} \mathrm{C} \\
\text { t: } 120 \text { min }\end{array}$ & $65.8 \%$ & [37] \\
\hline 8 & Zeolite FAU (100) & \multirow{4}{*}{ Phenol } & \multirow{4}{*}{$\begin{array}{l}\mathrm{C}_{\text {adsorbent }}: 20 \mathrm{gL}^{-1} \\
\mathrm{C}_{\text {phenol }}: 1.6 \mathrm{gL}^{-1} \\
\text { no pH adjustment; } \mathrm{T}: 25^{\circ} \mathrm{C} \\
\text { t: } 60 \mathrm{~min}\end{array}$} & $65.0 \%$ & \multirow{4}{*}{ [36] } \\
\hline 9 & Zeolite MOR (80) & & & $50.0 \%$ & \\
\hline 10 & Zeolite MFI (500) & & & $70.0 \%$ & \\
\hline 11 & Zeolite BEA $(\infty)$ & & & $85.0 \%$ & \\
\hline 12 & Activated carbon (SP1000) & \multirow{2}{*}{$\begin{array}{l}\text { Phenol, real real syngas } \\
\text { scrubber wastewater }\end{array}$} & \multirow{2}{*}{$\begin{array}{l}\mathrm{C}_{\text {adsorbent }}: 80 \mathrm{gL}^{-1} \\
\mathrm{C}_{\text {phenol }}: 5 \mathrm{gL}^{-1} \\
\text { no pH adjustment; } \mathrm{T}: 25^{\circ} \mathrm{C} \\
\text { t: } 24 \mathrm{~h}\end{array}$} & $\begin{array}{c}\text { Phenol: } 96.0 \% \\
\text { Real wastewater: } 92.0 \%\end{array}$ & [39] \\
\hline 13 & Biochar (SPBCG) & & & $\begin{array}{c}\text { Phenol: } 64.0 \% \\
\text { Real wastewater: } 25.0 \%\end{array}$ & [39] \\
\hline
\end{tabular}

Notes: $\mathrm{C}_{\text {adsorbent }}=$ adsorbent concentration, $\mathrm{C}_{\text {phenol }}=$ initial phenol concentration, $\mathrm{T}=$ temperature, $\mathrm{t}=$ adsorption time. 


\subsubsection{Liquid-Liquid Extraction}

Liquid-liquid extraction (LLE) is a non-destructive method for separating compounds based on their relative solubility. LLE process is applicable to treat phenolic compounds in water at various phenol concentrations [43]. The variables that affect LLE using cumene to remove phenol from aqueous solution are $\mathrm{pH}$ and temperature. Phenol removal increases with increasing temperature. Therefore, this method can be used in various phenol concentrations (50-2200 mg/L) [44].

The main principle of LLE for separating phenol from wastewater is to choose an appropriate extractant with the solubility of phenol in extractant must be much higher than the solubility of phenol in water. Then, after mixing, the equilibrium of phenol concentration between the wastewater phase $(W)$ and extractant phase $(R)$ is completed and completely separated (Figure 8) [45].

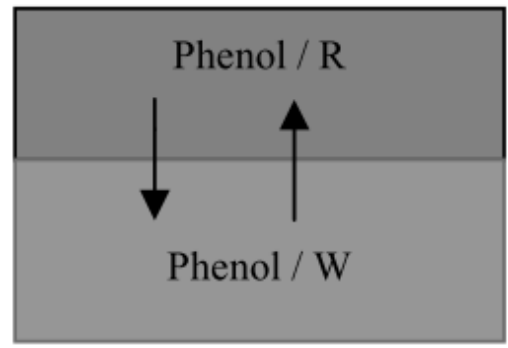

Figure 8. Schematic of liquid-liquid extraction. Adapted from Ref. [45]. Copyright 2003 Elsevier.

Jiang et al. [45] investigated the removal of phenol from wastewater containing $6000 \mathrm{mg} / \mathrm{L}$ of phenol by the LLE method using octanol $\left(\mathrm{C}_{8} \mathrm{H}_{17} \mathrm{OH}\right)$ as an extractant. Phenolic wastewater and extractant were mixed at $1 \mathrm{~atm}$, ambient temperature, and $\mathrm{pH} 3.0$. Optimum phenol removal efficiency from wastewater (more than $99 \%$ ) could be achieved if the separation factor $(\mathrm{Sf})=750$, with a rotational speed of $1300 \mathrm{rpm}$, and oar diameter of $2 \mathrm{~cm}$. The extractive and separated times were $2 \mathrm{~h}$ so that the mass transfer and phases separation were completed. Rao et al. [46] also studied batch liquid-liquid extraction of phenol in sebacic acid wastewater (SAWW) with a phenol concentration of about $2500 \mathrm{mg} / \mathrm{L}$. This experiment used a variety of extractants, such as hexanol, heptanol, octanol, castor oil, aliquat-336, and mixture of octanol-aliquat-336. The optimum result obtained at a temperature of $30{ }^{\circ} \mathrm{C}$ showed a phenol removal efficiency of $92 \%$ in the presence of a mixture of octanol-Aliquat-336 (5:5 ratio) as an extractant. In another study, methyl isobutyl ketone (MIBK) was also used as an extractant in the LLE batch of phenol removal from an aqueous solution [14]. A comparison of the efficiency of phenol degradation in wastewater through the LLE process is shown in Table 5. Based on Table 5, the optimum $\mathrm{pH}$, temperature, and pressure for the LLE process are $3-5,25^{\circ} \mathrm{C}$, and $1 \mathrm{~atm}$.

Table 5. Comparison of phenol removal efficiency in wastewater using various extractants via liquid-liquid extraction (LLE) process.

\begin{tabular}{|c|c|c|c|c|}
\hline Extractant & Phenolic Compound & Operating Conditions & Efficiency of Removal & Ref. \\
\hline Ethyl acetate & Phenols in olive mill wastewater & $\begin{array}{l}\text { P: } 1 \mathrm{~atm} \\
\text { T: } 25^{\circ} \mathrm{C} \\
\text { pH: } 2 \\
\text { t: } 5 \mathrm{~min}\end{array}$ & $87.0 \%$ & [47] \\
\hline Ethyl acetate & \multirow{2}{*}{$\begin{array}{l}\text { Phenolic compounds in olive } \\
\text { mill waste water (OMWW) }\end{array}$} & $\begin{array}{l}\text { P: } 1 \text { atm } \\
\text { T: n.a. } \\
\text { pH: n.a. } \\
\text { t: n.a. }\end{array}$ & $85.5 \%$ & [48] \\
\hline Ethyl acetate & & $\begin{array}{l}\text { P: } 1 \text { atm } \\
\text { T: } 100{ }^{\circ} \mathrm{C} \\
\text { pH: n.a. } \\
\text { t: } 30 \text { min }\end{array}$ & $>90.0 \%$ & [49] \\
\hline
\end{tabular}


Table 5. Cont.

\begin{tabular}{|c|c|c|c|c|}
\hline Extractant & Phenolic Compound & Operating Conditions & Efficiency of Removal & Ref. \\
\hline Cumene & Phenol & $\begin{array}{l}\text { P: } 1 \mathrm{~atm} \\
\mathrm{~T}: 25^{\circ} \mathrm{C} \\
\text { pH: } 7 \\
\text { t: } 30 \mathrm{~min}\end{array}$ & $\sim 80.0 \%$ & [44] \\
\hline $\mathrm{C}_{8} \mathrm{H}_{17} \mathrm{OH}$ & Phenol & $\begin{array}{l}\text { P: } 1 \text { atm } \\
\text { T: } 25^{\circ} \mathrm{C} \\
\text { pH: } 3 \\
\text { t: } 2 \text { h } 3 \text { min }\end{array}$ & $>99.0 \%$ & [45] \\
\hline Octanol-Aliquat-336 & $\begin{array}{l}\text { Phenol in sebacic acid } \\
\text { wastewater (SAWW) }\end{array}$ & $\begin{array}{l}\text { P: } 1 \text { atm } \\
\text { T: } 30^{\circ} \mathrm{C} \\
\text { pH: n.a. } \\
\text { t: } 40 \text { min }\end{array}$ & $92.0 \%$ & [46] \\
\hline Methyl isobutyl ketone (MIBK) & Phenol & $\begin{array}{l}\text { P: } 1 \mathrm{~atm} \\
\text { T: } 25^{\circ} \mathrm{C} \\
\text { pH: } 8 \\
\text { t: } 120 \mathrm{~min}\end{array}$ & $>93.0 \%$ & {$[50]$} \\
\hline $\begin{array}{l}\text { Combination of } 20 \% \\
\text { tributyl-phosphane (TBP), } 20 \% \\
\text { diethyl carbonate (DEC), } \\
\text { and } 60 \% \text { cyclohexane }\end{array}$ & Phenol & $\begin{array}{l}\text { P: } 1 \mathrm{~atm} \\
\text { T: } 25^{\circ} \mathrm{C} \\
\text { pH: } 5.05 \\
\text { t: } 5 \text { min }\end{array}$ & $>99.8 \%$ & {$[51]$} \\
\hline
\end{tabular}

Notes: $\mathrm{P}=$ pressure, $\mathrm{T}=$ temperature, $\mathrm{t}=$ extraction time.

\subsection{Advanced Technologies}

\subsubsection{Chemical Oxidation}

Chemical oxidation is a destructive method for treating aqueous phenol wastewater. The most common chemicals used in this process are ozone, chlorine, chlorine dioxide, chloramines, ferrate [Fe (VI)], and permanganate [Mn (VII)]. This process has several advantages such as a low amount of reagent, low energy costs, operating under mild temperatures, and $\mathrm{pH}$ conditions [15]. However, the formation of recalcitrant chemicals may occur during some of these processes [35]. This technique can also be combined with biological treatment for phenolic compound removal. Rubalcaba et al. reported promising results by combining these two processes to treat toxic and non-biodegradable contaminants [52].

Chamberlin et al. [53] investigated the chemical oxidation of phenolic effluents with chlorine on the laboratory scale and pilot plant scale. Combining chlorine with higher phenolic compounds usually produces chloro-derivatives that are more complex than phenol itself to degrade. These compounds give rise to taste and odors in the water, but significantly higher concentrations can be tolerated. Therefore, even discharges from various manufacturing plants contain small amounts of various phenolic compounds and it will bring problems to the stream indicating that phenol must be completely removed from the effluent, either by recovery or destruction. The reaction between phenols and chlorine relies on the $\mathrm{pH}$ of the solution after chlorination. Chlorination at a $\mathrm{pH}$ above 7 can damage phenol. However, when the following solution shows a pH below 7, it leads to the formation of chloro-phenolic derivatives. In this study, chlorine was applied as hypochlorite, the $\mathrm{pH}$ was adjusted, the chlorine dose and reaction period also varied. It has been proven that phenol not only can be oxidized rapidly with chlorine with an efficiency of removal of almost $100 \%$ but it can also remove color and odor. Another study stated that when phenol solution was reacted with a low dose of hypochlorite, chlorophenol was formed. Otherwise, phenol can be destroyed in larger amounts of hypochlorite [54].

The Fenton oxidation process is one of the most suitable and effective methods for reducing organic pollutants. Some of the advantages of the oxidation process are its wide application range, strong anti-interference ability, easy operation, and fast degradation and mineralization $[55,56]$. However, the disadvantages of this process are the narrow 
working $\mathrm{pH}$ range, high costs and risks associated with handling, transport, and storage of reagents $\left(\mathrm{H}_{2} \mathrm{O}_{2}\right.$ and catalysts), significant iron sludge associated with problematic secondary pollution, and expensive disposal [57]. Eisenhauer et al. [54] investigated the application of Fenton's reagent as an oxidant to remove phenol from synthetic and industrial wastewater. Fenton's reagent was successfully used under mild conditions in a synthetic phenol solution to completely oxidize phenol. However, when the reagent was applied to certain industrial phenolic wastewater, three to six times hydrogen peroxide was required to produce the same yield as that in synthetic phenol solution. The chemical cost required to use Fenton's reagent to remove phenol from industrial wastewater was calculated to be around USD $5.30 / \mathrm{kg}$ phenol destroyed, which is more expensive compared to biological oxidation processes. However, the chemical oxidation of phenol effluent with hydrogen peroxide can be applied to industries specializing in intermittent batch operations. Table 6 shows the comparison of the efficiency of phenolic compound removal using chemical oxidation processes with various oxidants. The optimum $\mathrm{pH}$, temperature, and pressure for phenol removal using the chemical oxidation process are in the range of $8-12,20-45^{\circ} \mathrm{C}$, and $1 \mathrm{~atm}$, respectively.

Table 6. Effectiveness comparison of various oxidants for phenol-based removal via chemical oxidation process in the aqueous phase.

\begin{tabular}{|c|c|c|c|c|c|}
\hline Oxidant & Phenolic Compound & \multicolumn{2}{|c|}{ Operating Conditions } & $\begin{array}{l}\text { Efficiency of Organic } \\
\text { Compound Removal }\end{array}$ & Ref. \\
\hline $\mathrm{KMnO}_{4}$ & \multirow{2}{*}{ Phenolic wastes } & $\begin{array}{l}\text { P: } 1 \mathrm{~atm} \\
\text { T: } 95^{\circ} \mathrm{C} \\
\text { pH: }>7 \\
\text { t: n.a. } \\
\text { C }_{\text {phenol }}: 125 \text { ppm } \\
\text { C }_{\text {KMnO4 }} \text { : n.a. }\end{array}$ & & $62.4 \%$ & \multirow{3}{*}{ [53] } \\
\hline $\mathrm{ClO}^{-}$ & & $\begin{array}{l}\text { P: } 1 \mathrm{~atm} \\
\text { T: } 45^{\circ} \mathrm{C} \\
\text { pH: } 10.5-12 \\
\text { t: } 20 \mathrm{~h} \\
\mathrm{C}_{\text {phenol }}: \text { n.a. } \\
\mathrm{C}_{\mathrm{ClO}^{-}}: 0-7500 \mathrm{ppm}\end{array}$ & & $\sim 100.0 \%$ & \\
\hline Chlorine & Phenol with chlorine & $\begin{array}{l}\text { P: } 1 \text { atm } \\
\text { T: } 45^{\circ} \mathrm{C} \\
\text { pH: }>7 \\
\text { t: } 12-18 \text { min } \\
C_{\text {phenol }}: \text { n.a. } \\
\text { C }_{\text {chlorine }}: 4000 \text { ppm }\end{array}$ & & $96.6 \%$ & \\
\hline $\mathrm{K}_{2} \mathrm{FeO}_{4}$ & \multirow{3}{*}{ Phenol } & \multirow{3}{*}{$\begin{array}{l}\text { P: } 1 \text { atm } \\
\text { T: n.a. } \\
\text { Cphenol }: 30 \mathrm{mg} / \mathrm{L} \\
\text { pH: } 9 \\
\text { t: } 1 \text { h }\end{array}$} & $\mathrm{C}_{\mathrm{K} 2 \mathrm{FeO} 4}: 63 \mathrm{mg} / \mathrm{L}$ & $57.0 \%$ & \multirow{3}{*}{ [58] } \\
\hline $\mathrm{KMnO}_{4}$ & & & $\mathrm{C}_{\mathrm{KMnO} 4}: 50 \mathrm{mg} / \mathrm{L}$ & $70.0 \%$ & \\
\hline $\mathrm{Ca}(\mathrm{ClO})_{2}$ & & & $\mathrm{C}_{\mathrm{CaClO} 2}: 22.8 \mathrm{mg} / \mathrm{L}$ & $61.0 \%$ & \\
\hline $\mathrm{KMnO}_{4}$ & Bisphenol A (BPA) & $\begin{array}{l}\text { P: } 1 \mathrm{~atm} \\
\text { T: } 20^{\circ} \mathrm{C} \\
\text { pH: } 7 \\
\text { t: } 15 \mathrm{~min} \\
\mathrm{C}_{\mathrm{BPA}}=5 \mu \mathrm{M} \\
\mathrm{C}_{\mathrm{KMnO} 4}=10 \mu \mathrm{M}\end{array}$ & & $>99.0 \%$ & [59] \\
\hline
\end{tabular}




\subsubsection{Electrochemical Oxidation}

Electrochemical oxidation is an effective way to treat aqueous phenol effluent without the need for reagents but requires incurring equipment and energy costs. In addition, electrochemical oxidation can be applied to processes that have low capacity and have safety concerns in handling hazardous chemicals [15,35]. This method is divided into direct and indirect oxidation. Direct oxidation or anodic treatment occurs through the adsorption of the pollutants to the surface of the anode without the participation of other substances in solutions, except for electrons which are referred to as "pure reagents". $\mathrm{Pt}, \mathrm{PbO}_{2}$, $\mathrm{SnO}_{2}, \mathrm{IrO}_{2}$, and boron-doped diamond (BDD) are among the various anodes used in this method. Parameters that affect processing efficiency are current density, $\mathrm{pH}$, anode material, and electrolyte. Phenol degradation follows pseudo-first-order kinetics, and the effectiveness of the process is indicated by clear current efficiency, electrochemical oxidation index, or intermittent current efficiency [60,61]. However, the main problem of direct oxidation is electrode fouling, which decreases its catalytic activity. Figure 9 shows a schematic of the anodic oxidation mechanism of organic compounds with simultaneous oxygen evolution at the inactive anode (reactions a, b, and e) and at the active anode (reactions a, c, d, and f) where $\mathrm{M}, \mathrm{MO}$, and $\mathrm{R}$ attributed to metal, metal oxide, and organic compounds, respectively. The step by step mechanisms of electrochemical oxidation are shown in Equations (1)-(6) as follows: [60]

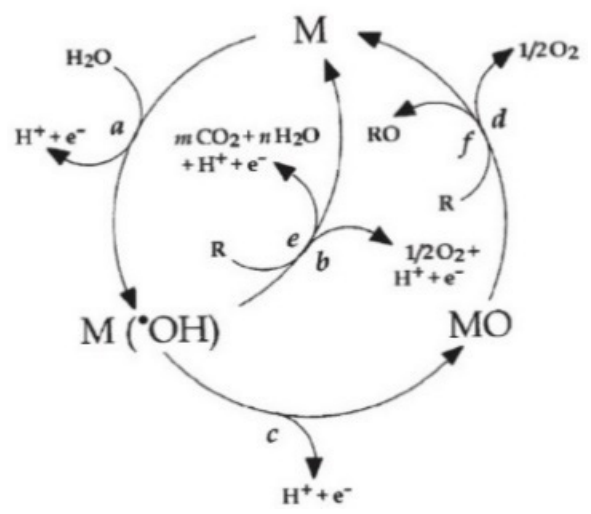

Figure 9. Schematic mechanism of anodic oxidation of organic compounds with simultaneous oxygen evolution at the inactive anode (reactions $a, b$, and e) and at the active anode (reactions $a, c, d$, and f). Reproduced from Ref. [60]. Copyright 2006 Royal Society of Chemistry.

Formation of hydroxyl radical, $\bullet \mathrm{OH}$;

$$
\mathrm{M}+\mathrm{H}_{2} \mathrm{O} \rightarrow \mathrm{M}(\bullet \mathrm{OH})+\mathrm{H}^{+}+\mathrm{e}^{-}
$$

Oxygen evolution of hydroxyl radicals by electrochemical oxidation;

$$
\mathrm{M}(\bullet \mathrm{OH}) \rightarrow \mathrm{MO}+\mathrm{H}^{+}+\mathrm{e}^{-}
$$

Formation of the higher metal oxide, $\mathrm{MO}$;

$$
\mathrm{MO}+\mathrm{R} \rightarrow \mathrm{M}+\mathrm{RO}
$$

Oxygen evolution of MO by chemical decomposition;

$$
\mathrm{MO} \rightarrow \mathrm{M}+1 / 2 \mathrm{O}_{2}
$$

Electrochemical combustion of the organic compound via hydroxyl radicals;

$$
\mathrm{M}(\bullet \mathrm{OH})+\mathrm{R} \rightarrow \mathrm{M}+\mathrm{mCO}_{2}+\mathrm{nH}_{2} \mathrm{O}+\mathrm{H}^{+}+\mathrm{e}^{-}
$$


Electrochemical conversion of the organic compound, R, via metal oxide.

$$
\mathrm{M}(\bullet \mathrm{OH}) \rightarrow \mathrm{M}+1 / 2 \mathrm{O}_{2}+\mathrm{H}^{+}+\mathrm{e}^{-}
$$

Moreover, indirect oxidation utilizes a redox intermediate reagent to affect the direct electron transfer between the electrode and the pollutant and consequently avoids fouling of the electrode by contaminants. The oxidizing agents can be a metal redox partner with a high oxidation potential, such as Ag (I/II), Ce (III/IV), Co (II/III), or strong oxidizing agents such as activated chlorine, ozone, hydrogen peroxide, persulphate, percarbonate, and perphosphate. The existence of chloride ions in wastewater increases phenol removal through the formation of $\mathrm{Cl}_{2}$ or $\mathrm{ClO}^{-}$. This process is called electrochemical oxidation of activated chlorine (Figure 10) [60].

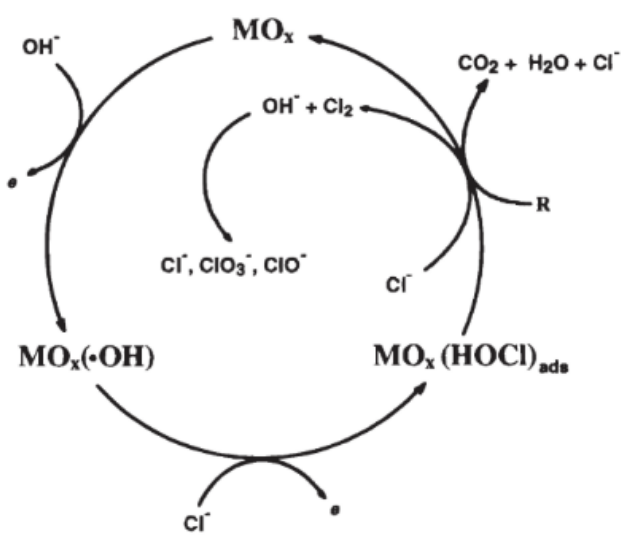

Figure 10. Schematic of electrochemical oxidation of organics by activated chlorine. Reproduced from Ref. [56]. Copyright 2006 Royal Society of Chemistry.

Saratale et al. [62] studied the electrochemical oxidation of phenol in wastewater using $\mathrm{Ti} / \mathrm{PbO}_{2}$ as an electrode. The Ti/ $\mathrm{PbO}_{2}$ electrode included $\mathrm{PbO}_{2}$ coated on Ti prepared by the electrodeposition method. Experiments have focused on the optimization of various parameters such as current density, initial concentration of phenol, initial $\mathrm{pH}$ of the solution, temperature, and dose of $\mathrm{Fe}^{2+}$ on the electrochemical degradation of phenol using $\mathrm{Ti} / \mathrm{PbO}_{2}$. As a result, the complete removal of phenol $(250 \mathrm{mg} / \mathrm{L})$ was observed at a temperature of $50{ }^{\circ} \mathrm{C}$, with potential differences of $5 \mathrm{~V}$, and at $\mathrm{pH} 2$ after $9 \mathrm{~h}$. Table 7 shows the comparison of phenol degradation using different types of electrodes via the electrochemical oxidation process.

Table 7. Comparison of phenol degradation study using different types of electrodes via the electrochemical oxidation process.

\begin{tabular}{|c|c|c|c|c|c|}
\hline Electrode & Phenolic Compound & $\begin{array}{l}\text { Phenol Concentration } \\
(\mathrm{mg} / \mathrm{L})\end{array}$ & $\begin{array}{l}\text { Operating } \\
\text { Conditions }\end{array}$ & $\begin{array}{c}\text { Efficiency of } \\
\text { Removal }\end{array}$ & Ref. \\
\hline $\mathrm{Ti} / \mathrm{PbO}_{2}$ & Phenol & 50 & $\begin{array}{l}\text { pH: } 5.5 \\
\text { T: } 30^{\circ} \mathrm{C} \\
\text { t: } 180 \mathrm{~min} \\
\text { J: } 20 \mathrm{~mA} \mathrm{~cm}^{-2}\end{array}$ & $72 \%$ & [63] \\
\hline $\mathrm{Ti} / \mathrm{PbO}_{2} \cdot \mathrm{Sn}$ & Phenol & 500 & $\begin{array}{l}\text { pH: } 5.5 \\
\text { T: } 30^{\circ} \mathrm{C} \\
\text { t: } 180 \mathrm{~min} \\
\text { J: } 20 \mathrm{~mA} \mathrm{~cm}^{-2}\end{array}$ & $89 \%$ & [64] \\
\hline $\mathrm{Ti} / \mathrm{PbO}_{2} \cdot \mathrm{Sb} / \mathrm{PbO}_{2}$ & 4-chloro-3-methyl phenol & 99.8 & $\begin{array}{l}\mathrm{pH}: 5.5 \\
\mathrm{~T}: 30^{\circ} \mathrm{C} \\
\mathrm{t}: 180 \mathrm{~min} \\
\mathrm{~J}: 20 \mathrm{~mA} \mathrm{~cm}^{-2}\end{array}$ & $100 \%$ & [65] \\
\hline
\end{tabular}


Table 7. Cont.

\begin{tabular}{|c|c|c|c|c|c|}
\hline Electrode & Phenolic Compound & $\begin{array}{c}\text { Phenol Concentration } \\
(\mathrm{mg} / \mathrm{L})\end{array}$ & $\begin{array}{l}\text { Operating } \\
\text { Conditions }\end{array}$ & $\begin{array}{l}\text { Efficiency of } \\
\text { Removal }\end{array}$ & Ref. \\
\hline $\mathrm{Ti} / \mathrm{RuO}_{2}$ & p-nitrophenol & 100 & $\begin{array}{l}\text { pH: } 5.5 \\
\text { T: } 30^{\circ} \mathrm{C} \\
\text { t: } 180 \mathrm{~min} \\
\mathrm{~J}: 20 \mathrm{~mA} \mathrm{~cm}^{-2}\end{array}$ & $100 \%$ & [66] \\
\hline $\mathrm{Ti} / \mathrm{Sb}-\mathrm{SnO}_{2}$ & 4-chlorophenol & 128.6 & $\begin{array}{l}\text { pH: } 5.5 \\
\text { T: } 30^{\circ} \mathrm{C} \\
\text { t: } 180 \mathrm{~min} \\
\text { J: } 20 \mathrm{~mA} \mathrm{~cm}{ }^{-2}\end{array}$ & $51 \%$ & {$[67]$} \\
\hline $\mathrm{Ti} / \mathrm{SnO}_{2} \cdot \mathrm{Sb}_{2} \mathrm{O}_{3} \cdot \mathrm{Nb}_{2} \mathrm{O}_{5} / \mathrm{PbO}_{2}$ & Phenol & 500 & $\begin{array}{l}\text { pH: } 5.5 \\
\text { T: } 30^{\circ} \mathrm{C} \\
\text { t: } 180 \mathrm{~min} \\
\text { J: } 20 \mathrm{~mA} \mathrm{~cm}{ }^{-2}\end{array}$ & $78.6 \%$ & {$[68]$} \\
\hline Er-chitosan-F- $\mathrm{PbO}_{2}$ & 2,4-dichlorophenol & 90 & $\begin{array}{l}\text { pH: } 5.5 \\
\text { T: } 30^{\circ} \mathrm{C} \\
\text { t: } 180 \mathrm{~min} \\
\text { J: } 20 \mathrm{~mA} \mathrm{~cm}^{-2}\end{array}$ & $95 \%$ & [69] \\
\hline Ti-base $\mathrm{CeO}_{2} / \beta-\mathrm{PbO}_{2}$ & $\begin{array}{l}\text { 4,4'-(propane-2,2-diyl) } \\
\text { diphenol }\end{array}$ & 20 & $\begin{array}{l}\text { pH: } 5.5 \\
\text { T: } 30^{\circ} \mathrm{C} \\
\text { t: } 180 \mathrm{~min} \\
\mathrm{~J}: 20 \mathrm{~mA} \mathrm{~cm}{ }^{-2}\end{array}$ & $100 \%$ & {$[70]$} \\
\hline $\mathrm{Ti} / \mathrm{PbO}_{2}$ & phenol & 250 & $\begin{array}{l}\text { pH: } 5.5 \\
\text { T: } 30^{\circ} \mathrm{C} \\
\text { t: } 180 \mathrm{~min} \\
\mathrm{~J}: 20 \mathrm{~mA} \mathrm{~cm}^{-2}\end{array}$ & $100 \%$ & {$[62]$} \\
\hline
\end{tabular}

Notes: $\mathrm{T}=$ temperature, $\mathrm{t}=$ time, $\mathrm{J}=$ current density.

\subsubsection{Membrane Process}

Membrane technology is a definite and economically feasible process for removing phenol from aqueous solutions. Membrane-based solvent extraction (MBSE) technology is one of the most commonly used technologies in phenol treatment including liquid membranes, membrane bioreactors (MBR), extractive membrane bioreactors (EMBR), hollow fiber membranes, photocatalytic membrane reactors, reverse osmosis, high-pressure membrane processes (nanofiltration and pervaporation) and membrane distillation. Membrane processes are divided based on driving forces, such as concentrationdriven (liquid membranes), pressure-driven (nanofiltration, reverse osmosis, pervaporation), and thermal-driven (membrane distillation). In general, several factors affect membrane performance [71]: (1) membrane properties: pore size, hydrophilicity/hydrophobicity, residence time, permeability, surface charge; (2) properties of the target compounds: molecular size, charge, solubility, diffusivity, $\mathrm{pH}$, polarity; and (3) operating conditions (feed temperature, feed quality, flux, rejection/recovery). Membrane technology has many advantages, such as high-quality effluent, low power consumption, small footprint, and easy scalability with membrane modules. However, membrane fouling, which can occur due to particles and colloids present in the feed stream, should be considered [14,15].

MBR is a membrane-based biological separation and is sufficient to degrade priority pollutants. MBR uses membranes (micro- or ultrafiltration) coupled with conventional biological processes, and this process is efficient for removing phenol with high concentrations of phenolic compound in the feed stream. In contrast, EMBR is a combination of biodegradation and membrane extraction processes. First, EMBR uses a non-porous membrane responsible for solution diffusion to transport the target substance controlled by a concentration difference. Then the membrane transport target substance is degraded using microorganisms at the receiving end [3,72].

The principle of the MBSE process combines solvent extraction with high compactness and the interfacial exchange area provided by the hollow fiber membrane contactor. In phenol removal from solution, the membrane acts as a physical barrier between phenol and water to facilitate immobilization of the aqueous phase by applying transmembrane 
pressure difference. The concentration gradient that drives the extraction and the transfer operation is independent of the transmembrane pressure [3,14].

Reverse osmosis is a membrane-based demineralization technique for separating dissolved solids from water-based solutions, especially ions. Nanofiltration is a membranebased filtration method that uses nanometer-sized pores $(1-10 \mathrm{~nm})$ and a widely used separation technique to remove organic pollutants, inorganic salts, color, and hardness from aqueous solutions [15].

Pervaporation is a membrane-based separation technique to remove low-volatility organic compounds from wastewater. The pervaporation separation ability is also related to both the relative diffusivity and solubility of the components in the membrane. As a result, the water separates on the feed side, and steam separates on the permeate side and simultaneously evaporates the permeating compound (Figure 11). Some of the advantages of the pervaporation method are minimal energy consumption, no secondary contamination, high efficiency, and easy operation $[15,24,73]$.

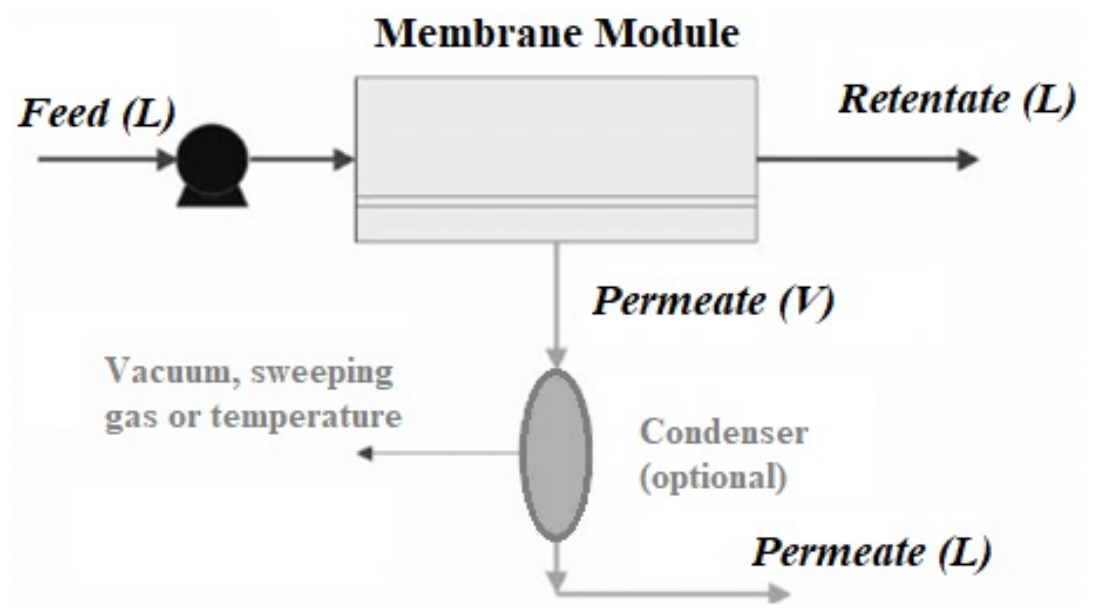

Figure 11. General schematic of a pervaporation process. Reproduced from Ref. [73]. Copyright 2006 Taylor \& Francis Online.

The membrane distillation process is a non-isothermal membrane-based separation that is effective in repelling non-volatile substances. Membrane distillation is driven by the vapor pressure difference across the membrane and uses a hydrophobic membrane that acts as a barrier to hold the liquid/vapor interfaces at the entrance pores [74]. Table 8 shows several types of membrane technologies that have been applied to remove phenol from aqueous solutions. The optimum temperature and pressure for phenol removal using membrane technologies are under ambient conditions (temperature of $25^{\circ} \mathrm{C}$ and pressure of $1 \mathrm{~atm})$, respectively.

Table 8. Comparison of the efficiency for phenolic compounds removal using different types of membrane materials and membrane technologies.

\begin{tabular}{|c|c|c|c|c|c|c|}
\hline No & $\begin{array}{l}\text { Membrane } \\
\text { Technology }\end{array}$ & Membrane Material & $\begin{array}{l}\text { Phenolic } \\
\text { Compound }\end{array}$ & $\begin{array}{l}\text { Operating } \\
\text { Condition }\end{array}$ & $\begin{array}{l}\text { Efficiency of } \\
\text { Removal (\%) }\end{array}$ & Ref. \\
\hline 1 & ELM & SPAN80 & Phenol & $\begin{array}{l}\text { P: } 1 \mathrm{~atm} \\
\mathrm{~T}: 25^{\circ} \mathrm{C} \\
\mathrm{t}: 4 \mathrm{~min}\end{array}$ & 98 & [75] \\
\hline 2 & MBR (sludge) & PVDF hollow fiber & $\begin{array}{l}\text { Bisphenol A } \\
\text { dan BHT }\end{array}$ & $\begin{array}{l}\text { P: } 1 \mathrm{~atm} \\
\text { T: } 25^{\circ} \mathrm{C} \\
\text { t: } 500 \text { days }\end{array}$ & 90 & {$[76]$} \\
\hline 3 & Nanofiltration & Polysulfone & $\begin{array}{l}2,4- \\
\text { Dinitrophenol }\end{array}$ & \multirow{2}{*}{$\begin{array}{l}\text { P: } 1 \mathrm{~atm} \\
\mathrm{~T}: 25^{\circ} \mathrm{C} \\
\mathrm{t}: 25 \mathrm{~h}\end{array}$} & $>95$ & [77] \\
\hline 4 & Nanofiltration & Polysulfone & p-Nitrophenol & & 90 & [77] \\
\hline
\end{tabular}


Table 8. Cont.

\begin{tabular}{|c|c|c|c|c|c|c|}
\hline No & $\begin{array}{l}\text { Membrane } \\
\text { Technology }\end{array}$ & Membrane Material & $\begin{array}{l}\text { Phenolic } \\
\text { Compound }\end{array}$ & $\begin{array}{l}\text { Operating } \\
\text { Condition }\end{array}$ & $\begin{array}{l}\text { Efficiency of } \\
\text { Removal (\%) }\end{array}$ & Ref. \\
\hline 5 & $\begin{array}{l}\text { Reverse } \\
\text { osmosis }\end{array}$ & RO 99 & Phenol & \multirow{3}{*}{$\begin{array}{l}\text { P: } 4 \text { bar } \\
\text { T: } 50{ }^{\circ} \mathrm{C} \\
\text { t: } 30 \mathrm{~min}\end{array}$} & 93 & [78] \\
\hline 6 & $\begin{array}{l}\text { Reverse } \\
\text { osmosis }\end{array}$ & SW & Phenol & & 81 & {$[78]$} \\
\hline 7 & $\begin{array}{l}\text { Reverse } \\
\text { osmosis }\end{array}$ & $\mathrm{RO} 98 \mathrm{pHt}$ & Phenol & & 84 & [78] \\
\hline 8 & $\begin{array}{l}\text { TPPOMBr } \\
\text { (P. putida) }\end{array}$ & $\begin{array}{l}\text { Commercial flat-sheet } \\
\text { cellulose triacetate FO } \\
\text { membranes }\end{array}$ & Phenol & $\begin{array}{l}\text { P: } 1 \text { atm } \\
\text { T: } 25^{\circ} \mathrm{C} \\
\text { t: } 5-6 \text { days }\end{array}$ & 100 & [79] \\
\hline
\end{tabular}

Notes: $\mathrm{T}=$ temperature, $\mathrm{P}=$ pressure, $\mathrm{t}=$ time.

\subsubsection{Supercritical Water Gasification}

Supercritical water gasification (SCWG) is a technology that allows the conversion of organic wastewaters into gaseous fuel with a high amount of hydrogen and light hydrocarbons [80]. Gasification is mainly controlled by the density, viscosity, and dielectric constant of water [81]. Supercritical water gasification (SCWG) is a reaction that uses water above its thermodynamic critical point $\left(\mathrm{Tc}=374{ }^{\circ} \mathrm{C}, \mathrm{Pc}=22.1 \mathrm{MPa}\right)$ as the reactant and reaction medium [82]. This process usually operates at temperatures range of $400-650{ }^{\circ} \mathrm{C}$ and pressure range of 250-350 bar [80]. SCWG exploits the unique properties of water in a supercritical state that exhibits transitional behavior between liquid and gas. It has a fairly high density and good resistance like a liquid, but still has the characteristics of diffusivity and gas reactivity [83]. Gas-like viscosity and liquid-like density are two properties that enhance mass transfer and solvation properties. Furthermore, when entering the supercritical phase, the dielectric constant of water decreases drastically. Changes in the thermophysical properties, especially loss of phase boundaries and non-polarity, provide opportunities for salt separation and gasification of tar-free biomass [81]. Under supercritical water conditions, phenol can be decomposed effectively. Phenol is also mainly gasified into $\mathrm{H}_{2}, \mathrm{CO}_{2}$, and $\mathrm{CH}_{4}$ under certain operating conditions (above $600{ }^{\circ} \mathrm{C}$ ) and an appropriate catalyst. Phenol and its derivatives are not only wastewater pollutants but also major components of lignin [84]. The main objective of SCWG is to produce hydrogen from wet biomass, concentrated organic wastewater, and organic solid waste at a relatively low temperature compared to conventional gasification processes $[85,86]$. Disadvantages of this method are thermal efficiency, clogging, and corrosion problems [81].

Guan et al. [84] studied the partial oxidative gasification of phenol in real coke wastewater in the temperature range of $573-753 \mathrm{~K}$ with an alkali salt $\left(\mathrm{Na}_{2} \mathrm{CO}_{3}\right)$ catalyst. The result showed that $75.6 \%$ of phenol could be removed in $40 \mathrm{~s}, 69.3 \%$ of TOC was gasified in $180 \mathrm{~s}$ as $2.7 \mathrm{~mol} / \mathrm{mol}$ of hydrogen was produced at temperature, pressure, and the molar ratio of oxygen to phenol are $723 \mathrm{~K}, 24 \mathrm{MPa}$, and 7:1, respectively. The partially catalyzed oxidative gasification of phenol in supercritical water was also studied by Xu et al. [87]. The experiments used $1 \mathrm{wt}-\%$ phenol with different oxidation coefficients and temperatures ranging from 430 to $550{ }^{\circ} \mathrm{C}$ with or without $0.1 \mathrm{wt}-\% \mathrm{Na}_{2} \mathrm{CO}_{3}$ as a catalyst. The gasification process occurred in a continuous tubular-flow reaction plant in supercritical water. The results showed that phenol was difficult to be gasified to produce hydrogen at the experimental temperatures, thus the catalyst had an important role in this experiment. The highest hydrogen yield reached its maximum value $(0.477 \mathrm{~mol} / \mathrm{mol})$, which was two-folds that without the catalyst when $0.1 \mathrm{wt} \% \mathrm{Na}_{2} \mathrm{CO}_{3}$ was added at $n=0.6$, the temperature of $500{ }^{\circ} \mathrm{C}$, and the residence time of $2.96 \mathrm{~min}$. [87].

Zhang et al. [86] investigated the effect of $\mathrm{NaOH}$ as a catalyst and $\mathrm{H}_{2} \mathrm{O}_{2}$ as an oxidant on the partial oxidation of phenol in supercritical water for hydrogen production and phenol polymerization. This experiment used a mini-batch reactor, which is built by sealing one end of a quartz tube. The experimental results showed that the presence of 
$\mathrm{NaOH}$ at a lower coefficient increased hydrogen production. In addition, the reaction with $\mathrm{NaOH}$ and $\mathrm{H}_{2} \mathrm{O}_{2}$ simultaneously increased hydrogen production and inhibited the formation of polycyclic polymers at oxidant to catalyst ratios below 0.5 compared to the individual catalytic partial oxidation of phenol. The optimum efficiency of hydrogen gasification was achieved around $62.35 \%$ at $400{ }^{\circ} \mathrm{C}, 22.5 \mathrm{MPa}$, and $900 \mathrm{~s}$. It was carried out at an oxidant to catalyst ratio of $0.3 \mathrm{with} 1.0 \mathrm{wt} \% \mathrm{NaOH}$, and the removal efficiency of phenol was close to $75 \%$ [86]. Figure 12 shows the reaction network model for catalytic supercritical water oxidation based on a phenol supercritical water gasification reaction network while Table 9 shows the comparison of the effectiveness of phenol removal from an aqueous solution through the supercritical water gasification process.

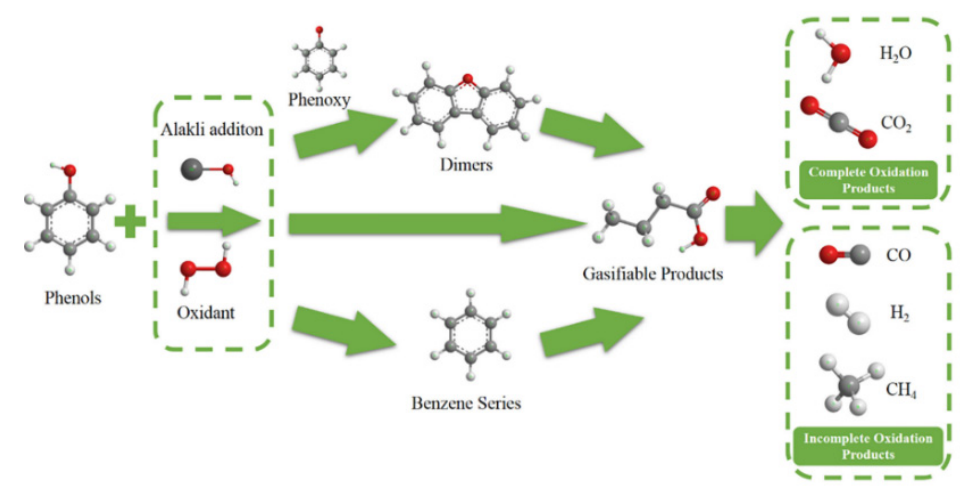

Figure 12. Reaction pathways for catalytic oxidation of phenol in supercritical water. Reproduced from Ref. [86]. Copyright 2020 Elsevier.

Table 9. Comparison of the effectiveness of phenol removal through the supercritical water gasification process.

\begin{tabular}{|c|c|c|c|c|c|c|}
\hline Catalyst & Oxidant & Reactor Type & Operating Condition & Hydrogen Production & $\begin{array}{c}\text { Efficiency of Phenol } \\
\text { Removal }\end{array}$ & Ref. \\
\hline $\mathrm{Na}_{2} \mathrm{CO}_{3}$ & Oxygen & Flow-type reactor & $\begin{array}{l}\text { P: } 24 \mathrm{MPa} \\
\text { T: } 450^{\circ} \mathrm{C} \\
\text { t: } 40 \mathrm{~s}\end{array}$ & $2.7 \mathrm{~mol} / \mathrm{mol}$ & $75.6 \%$ & [84] \\
\hline $\mathrm{Na}_{2} \mathrm{CO}_{3}$ & Oxygen & $\begin{array}{l}\text { Continuous } \\
\text { flow-tubular }\end{array}$ & $\begin{array}{l}\mathrm{P}: 36 \mathrm{MPa} \\
\mathrm{T}: 500{ }^{\circ} \mathrm{C} \\
\mathrm{t}: 178 \mathrm{~s}\end{array}$ & $0.477 \mathrm{~mol} / \mathrm{mol}$ & $96.7 \%$ & [87] \\
\hline $\mathrm{NaOH}$ & $\mathrm{H}_{2} \mathrm{O}_{2}$ & $\begin{array}{l}\text { Mini batch } \\
\text { reactor }\end{array}$ & $\begin{array}{l}\text { P: } 22.5 \mathrm{MPa} \\
\text { T: } 400^{\circ} \mathrm{C} \\
\text { t: } 900 \mathrm{~s}\end{array}$ & $62.35 \%$ & $75.0 \%$ & [86] \\
\hline
\end{tabular}

Notes: $\mathrm{T}=$ temperature, $\mathrm{P}=$ pressure, $\mathrm{t}=$ time.

\subsubsection{Ozonation}

Ozone is an unstable gas with a pungent odor and is partially soluble in water. In alkaline solutions, ozone is also a strong oxidizing agent with a redox potential of $2.07 \mathrm{~V}$, which is greater than the hypochlorite ion $(1.49 \mathrm{~V})$ or chlorine $(1.36 \mathrm{~V})$ [88]. The physiochemical properties of ozone are shown in Table 10.

The solubility of ozone strongly depends on temperature and is about 10 times more soluble in water than oxygen. These conditions make it possible to obtain relatively high ozone concentrations by saturating the water with an ozone/oxygen mixture from an oxygen-rich ozone generator. For example, the solubility of ozone is about twice as high as at $0{ }^{\circ} \mathrm{C}$ than at room temperature, as shown in Figure 13 [90].

Ozone is a chemical compound that can react selectively with many inorganic and organic substances, such as sulfites, nitrites, olefinic, phenols, polyaromatic hydrocarbon, organic amines, and sulfides [80]. In general, ozonation of contaminants can be carried out in two ways (Figure 14) namely direct reaction by ozone $\left(\mathrm{O}_{3}\right)$ molecules and indirect oxidation by $\bullet \mathrm{OH}$ (hydroxyl radicals) produced by $\mathrm{O}_{3}$ decomposition. 
Table 10. Physiochemical properties of ozone. Reproduced from Ref. [89]. Copyright 2020 Elsevier.

\begin{tabular}{ll}
\hline \multicolumn{1}{c}{ Property } & \multicolumn{1}{c}{ Value } \\
\hline Melting point, ${ }^{\circ} \mathrm{C}$ & -251 \\
Boiling point, ${ }^{\circ} \mathrm{C}$ & -112 \\
Critical pressure, atm & 54.62 \\
Critical temperature, ${ }^{\circ} \mathrm{C}$ & -12.1 \\
Specific gravity & 1.658 higher than air $1.71 \mathrm{~g} \mathrm{~cm}^{-3}\left(\mathrm{at}-183{ }^{\circ} \mathrm{C}\right)$ \\
Critical density, $\mathrm{kg} \mathrm{m}^{-3}$ & 436 \\
Heat of vaporization, $\mathrm{cal} \mathrm{mol}_{a}^{-1}$ & 2980 \\
Heat of formation, cal $\mathrm{mol}_{b}^{-1}$ & 33,880 \\
Free energy of formation, $\mathrm{cal} \mathrm{mol}_{b}^{-1}$ & 38,860 \\
Redox potential, $\mathrm{V}_{c}$ & 2.07 \\
\hline
\end{tabular}

a: at boiling point; $b$ : at $1 \mathrm{~atm}$ and $25^{\circ} \mathrm{C} ; c$ : at $\mathrm{pH}=0$.

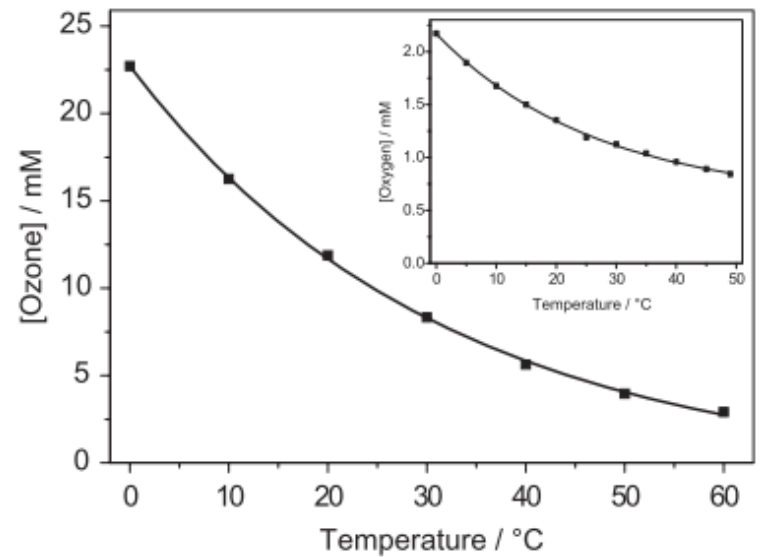

Figure 13. The solubility of ozone and oxygen in the water as a function of the temperature for pure gases. Reproduced from Ref. [90]. Copyright 2012 IWA Publishing.

Molecular ozone is capable of oxidizing water pollutants through direct, selective reactions or can undergo decomposition through a chain reaction mechanism resulting in the production of free hydroxyl radicals, namely the indirect pathway. The chemical properties of ozone depend on its molecular structure. Ozone molecules can be found in two types of chemical structures as shown in Figure 15.

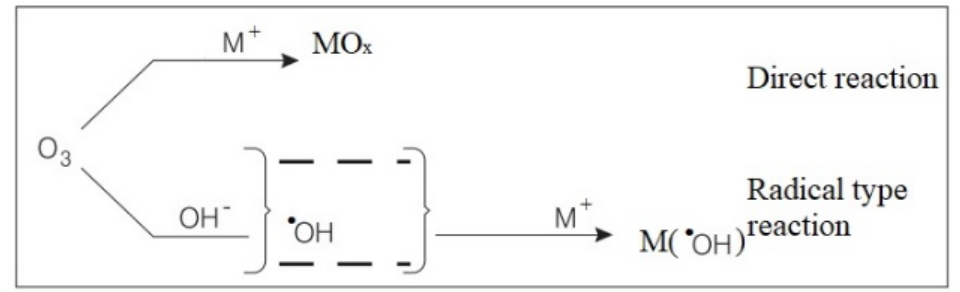

Figure 14. General schematic of reaction for ozonation of contaminants in an aqueous solution (M: metal, $\mathrm{MO}_{\mathrm{x}}$ : Metal oxide, and $\bullet \mathrm{OH}$ : hydroxyl radical). Reproduced from Ref. [88]. Copyright 2001 SciELO.

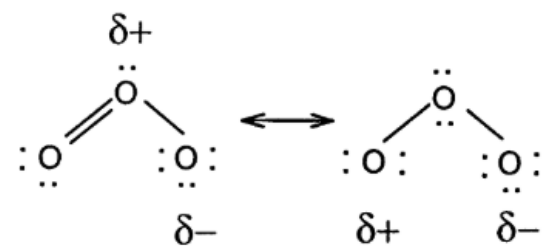

Figure 15. The chemical structure of ozone. Reproduced from Ref. [91]. Copyright 2003 Elsevier. 
Molecular ozone reacts as a dipole, electrophilic, or nucleophilic agent due to its chemical structure. Ozone is very unstable in water, it varies in half-life, a few seconds to several minutes, depending on $\mathrm{pH}$, water temperature, and concentrations of organic and inorganic compounds in the water [91]. Ozone decomposition follows a pseudo-first-order kinetic law as shown in Equation (7) [92]:

$$
-\left(\frac{d\left[O_{3}\right]}{d t}\right)_{p H}=k^{\prime}\left[O_{3}\right]
$$

where $k^{\prime}$ is a pseudo-first-order constant for a given $\mathrm{pH}$ value. The direct reaction of ozonation of contaminant by ozone $\left(\mathrm{O}_{3}\right)$ molecule can be in the form of an oxidationreduction reaction. Since ozone has a high standard redox potential (Table 9), it can react with many pollutants via an oxidation-reduction reaction, such as the reactions between $\mathrm{O}_{3}$ and $\mathrm{HO}_{2}{ }^{-}$as shown in Equations (8) and (9) [93]:

$$
\begin{gathered}
\mathrm{O}_{3}+\mathrm{HO}_{2}{ }^{-} \rightarrow \mathrm{O}_{3}{ }^{-}+\mathrm{HO}_{2} \\
\mathrm{O}_{3}+\mathrm{O}_{2}{ }^{-} \rightarrow \mathrm{O}_{3}{ }^{-}+\mathrm{O}_{2}
\end{gathered}
$$

Free hydroxyl radicals can be formed during ozone decomposition through indirect reaction and ozone decomposition can be reduced in the presence of hydroxyl radicals. The reaction proceeds through the following five-step chain as shown in Equations (10)-(14) [91]:

$$
\begin{gathered}
\mathrm{O}_{3}+\mathrm{H}_{2} \mathrm{O} \rightarrow 2 \bullet \mathrm{OH}+\mathrm{O}_{2}, \mathrm{k}=1.1 \times 10^{-4} \mathrm{M}^{-1} \mathrm{~s}^{-1} \\
\mathrm{O}_{3}+\mathrm{OH}^{-} \rightarrow \bullet \mathrm{O}_{2}^{-}+\mathrm{HO}_{2} \bullet \mathrm{k}=70 \mathrm{M}^{-1} \mathrm{~s}^{-1} \\
\mathrm{O}_{3}+\bullet \mathrm{OH} \rightarrow \mathrm{O}_{2}+\mathrm{HO}_{2} \bullet \rightleftharpoons \mathrm{O}_{2}^{-}+\mathrm{H}^{+} \\
\mathrm{O}_{3}+\mathrm{HO}_{2} \bullet \rightleftharpoons 2 \mathrm{O}_{2}+\bullet \mathrm{OH}, \mathrm{k}=1.6 \times 10^{9} \mathrm{M}^{-1} \mathrm{~s}^{-1} \\
2 \mathrm{HO}_{2}^{*} \rightarrow \mathrm{O}_{2}+\mathrm{H}_{2} \mathrm{O}_{2}
\end{gathered}
$$

The $\mathrm{pH}$ value of the solution greatly affects ozone decomposition in the water. The basic $\mathrm{pH}$ causes an increase in ozone decomposition. At $\mathrm{pH}<3$, hydroxyl radicals do not affect ozone decomposition. For $7<\mathrm{pH}<10$, the typical half-life time of ozone is from 15 to $25 \mathrm{~min}$ [91].

The ozonation process for the degradation of organic compounds has been widely developed for water purification. Some of the advantages of this process are as follows: (1) ozone can be converted into hydroxyl radicals and oxygen; (2) by using electricity or ultraviolet light, ozone can be generated easily; (3) ozone has a strong reactivity, which makes it effective in degrading organic compounds; (4) to improve water purification, ozone can be combined with other methods [94]. However, due to the selective oxidation between $\mathrm{O}_{3}$ and pollutants, the oxidation of some organic pollutants is relatively slow, resulting in incomplete removal of contaminants or generate toxic intermediate products. In addition, during the degradation of some organic pollutants by molecular ozone, some short-chain organic acids, such as carboxylic acids and aldehydes, may form and accumulate, which cannot be mineralized by ozone, leading to low mineralization efficiency [91]. In addition, the low solubility of ozone in the water will also cause low ozone efficiency, resulting in high operating costs. Generation of the disinfection by-products (DBPs) is also an important problem, which needs to be solved in the practical application of the ozonation process $[89,95]$. To overcome this problem, several advanced oxidation processes (AOPs) were developed [89]. Table 11 shows a comparison of the phenol removal effectiveness from an aqueous solution by ozone-based methods. 
Table 11. Comparison of the efficiency for phenolic compounds removal using ozonation and AOPs ozone-based technologies.

\begin{tabular}{|c|c|c|c|c|c|}
\hline Method & Reactor & Phenolic Compound & Operating Conditions & $\begin{array}{l}\text { Efficiency of } \\
\text { Removal }\end{array}$ & Ref. \\
\hline Ozonation & Tubular reactor & Phenol & $\begin{array}{l}\text { P: } 1 \mathrm{~atm} \\
\mathrm{~T}: 25^{\circ} \mathrm{C} \\
\text { t: } 60 \mathrm{~min} \\
\mathrm{pH}: 9-10 \\
\mathrm{C}_{\mathrm{O} 3}: 2.5 \mathrm{~g} \mathrm{O}_{3} / \mathrm{g} \text { phenol } \\
\mathrm{C}_{\text {phenol }}: 2000 \mathrm{mg} / \mathrm{L}\end{array}$ & $35 \%$ & [95] \\
\hline Ozonation & $\begin{array}{l}\text { Ozone bubble } \\
\text { column }\end{array}$ & Phenol & $\begin{array}{l}\text { P: } 1 \text { atm } \\
\text { T: } 25^{\circ} \mathrm{C} \\
\text { pH: } 9 \\
\text { t: } 40 \mathrm{~min} \\
\mathrm{C}_{\mathrm{O} 3}: 2 ; 4 ; 6 \mathrm{~g} / \mathrm{L} \\
\mathrm{C}_{\text {phenol }}: 50 ; 75 ; 100 \mathrm{mg} / \mathrm{L}\end{array}$ & $\sim 100 \%$ & [96] \\
\hline \multirow[b]{2}{*}{ Ozonation } & \multirow[b]{2}{*}{$\begin{array}{l}\text { Multi-injection } \\
\text { bubble column } \\
\text { reactor }\end{array}$} & Phenol & \multirow[b]{2}{*}{$\begin{array}{l}\text { P: } 1 \mathrm{~atm} \\
\mathrm{~T}: 29^{\circ} \mathrm{C} \\
\text { t: } 60 \mathrm{~min} \\
\mathrm{pH}: 12 \\
\mathrm{C}_{\mathrm{O} 3}: 0.6 \mathrm{mg} / \mathrm{L} \\
\mathrm{C}_{\text {phenol }}: 50 \mathrm{mg} / \mathrm{L}\end{array}$} & $98.7 \%$ & \multirow[b]{2}{*}{ [97] } \\
\hline & & 2,4-dichloro-phenol & & $99.83 \%$ & \\
\hline $\mathrm{O}_{3}$-Fenton & $\begin{array}{l}\text { Rotating packed } \\
\text { bed reactor }\end{array}$ & Phenol & $\begin{array}{l}\mathrm{P}: 1 \mathrm{~atm} \\
\mathrm{~T}: 25^{\circ} \mathrm{C} \\
\mathrm{pH}: 6.8 \\
\mathrm{C}_{\mathrm{O} 3}: 60 \mathrm{mg} / \mathrm{L} \\
\mathrm{C}_{\mathrm{phenol}}: 60 \mathrm{mg} / \mathrm{L} \\
\mathrm{C}_{\mathrm{H} 2 \mathrm{O} 2}: 1 \mathrm{mM} \\
\mathrm{C}_{\mathrm{Fe}(\mathrm{II})}: 0.1 \mathrm{mM}\end{array}$ & $87.5 \%$ & {$[98]$} \\
\hline $\begin{array}{l}\text { Ozonation- } \\
\text { adsorption } \\
\text { with GAC }\end{array}$ & $\begin{array}{l}\text { Rotating packed } \\
\text { bed reactor }\end{array}$ & Phenol & $\begin{array}{l}\text { P: } 1 \mathrm{~atm} \\
\text { T: } 20^{\circ} \mathrm{C} \\
\text { t: } 60 \mathrm{~min} \\
\text { pH: } 10 \\
\text { Q }_{\text {O3 }}: 3.31 \mathrm{mg} / \mathrm{min} \\
\mathrm{C}_{\text {phenol }}: 100 \mathrm{mg} / \mathrm{L} \\
\mathrm{m}_{\mathrm{GAC}}: 100 \mathrm{~g}\end{array}$ & $78.62 \%$ & [99] \\
\hline $\begin{array}{l}\mathrm{O}_{3}-\mathrm{Ca}(\mathrm{OH})_{2} \\
\text { System }\end{array}$ & $\begin{array}{l}\text { Micro Bubble } \\
\text { Gas-Liquid } \\
\text { Reactor }\end{array}$ & Phenol & $\begin{array}{l}\text { P: } 0.25 \mathrm{Mpa} \\
\mathrm{T}: 25^{\circ} \mathrm{C} \\
\text { t: } 30 \mathrm{~min} \\
\mathrm{pH}: 12 \\
\mathrm{Q}_{\mathrm{O} 3}: 3.5 \mathrm{~L} / \mathrm{min} \\
\mathrm{C}_{\mathrm{O} 3}: 65 \mathrm{mg} / \mathrm{L} \\
\mathrm{C}_{\mathrm{phenol}}: 450 \mathrm{mg} / \mathrm{L} \\
\mathrm{C}_{\mathrm{Ca}(\mathrm{OH}) 2}: 3 \mathrm{~g} / \mathrm{L}\end{array}$ & $\sim 100 \%$ & [100] \\
\hline $\mathrm{O}_{3}-\mathrm{UV}-\mathrm{TiO}_{2}$ & AOP reactor & Phenol & $\begin{array}{l}\text { P: } 1 \mathrm{~atm} \\
\text { T: } 25^{\circ} \mathrm{C} \\
\text { t: } 120 \mathrm{~min} \\
\text { pH: } 6 \\
\text { QO3 }: 0.03 \mathrm{mg} / \mathrm{min} \\
\mathrm{C}_{\mathrm{phenol}}: 50 \mathrm{mg} / \mathrm{L} \\
\lambda:<400 \mathrm{~nm}\end{array}$ & $100 \%$ & [101] \\
\hline $\mathrm{US}-\mathrm{H}_{2} \mathrm{O}_{2}-\mathrm{CuO}$ & $\begin{array}{l}\text { 520-kHz Undatim } \\
\text { Ortho Reactor }\end{array}$ & Phenol & $\begin{array}{l}\text { P: } 1 \mathrm{~atm} \\
\mathrm{~T}: 25^{\circ} \mathrm{C} \\
\text { t: } 136 \mathrm{~min} \\
\mathrm{C}_{\mathrm{phenol}}: 58.1 \mathrm{mg} / \mathrm{L} \\
\mathrm{C}_{\mathrm{H} 2 \mathrm{O} 2}: 10 \mathrm{mg} / \mathrm{L} \\
\mathrm{C}_{\mathrm{CuO}}: 1 \mathrm{mg} / \mathrm{mL}\end{array}$ & $84.81 \%$ & [102] \\
\hline
\end{tabular}


Table 11. Cont.

\begin{tabular}{|c|c|c|c|c|c|}
\hline Method & Reactor & Phenolic Compound & Operating Conditions & $\begin{array}{l}\text { Efficiency of } \\
\text { Removal }\end{array}$ & Ref. \\
\hline US-UV-O 3 & $\begin{array}{l}\text { Ultrasonic reactor } \\
\text { equipped with a } \\
\text { piezo-electric } \\
\text { transducer }\end{array}$ & Phenol & $\begin{array}{l}\mathrm{P}: 1 \mathrm{~atm} \\
\mathrm{~T}: 25^{\circ} \mathrm{C} \\
\mathrm{t}: 90 \mathrm{~min} \\
\text { pH: } 2 \\
\mathrm{Q}_{\mathrm{O} 3: 2 \mathrm{mg} / \mathrm{L}} \\
\mathrm{C}_{\mathrm{phenol}}: 235.28 \mathrm{mg} / \mathrm{L} \\
\lambda: 254 \mathrm{~nm}\end{array}$ & $90 \%$ & [103] \\
\hline SonaFenton & $\begin{array}{l}\text { The reactor of } 35 \\
\mathrm{kHz} \text { (Sonitubee) }\end{array}$ & Phenol & $\begin{array}{l}\text { P: } 1 \mathrm{~atm} \\
\text { T: } 25^{\circ} \mathrm{C} \\
\text { t: } 36.69 \mathrm{~min} \\
\mathrm{C}_{\text {phenol }}: 63 \mathrm{mg} / 1\end{array}$ & $90 \%$ & [104] \\
\hline $\mathrm{UV}-\mathrm{H}_{2} \mathrm{O}_{2}$ & $\begin{array}{l}\text { Batch cylindrical } \\
\text { glass photoreactor } \\
\text { of } 0.8 \mathrm{~L}\end{array}$ & Phenol & $\begin{array}{l}\text { P: } 1 \mathrm{~atm} \\
\mathrm{~T}: 25^{\circ} \mathrm{C} \\
\mathrm{t}: 90 \mathrm{~min} \\
\text { pH: } 3.5-4 \\
\mathrm{C}_{\text {phenol }}: 1000 \mathrm{mg} / \mathrm{L} \\
\mathrm{C}_{\mathrm{H} 2 \mathrm{O} 2}: 0-1.5 \mathrm{M} \\
\lambda: 200-450 \mathrm{~nm}\end{array}$ & $99.49 \%$ & [105] \\
\hline $\mathrm{O}_{3}-\mathrm{UV}$ & $\begin{array}{l}\text { Two identical } \\
\text { stainless steel } \\
\text { O3/UV reactors }\end{array}$ & PPCPs & $\begin{array}{l}\mathrm{P}: 1 \mathrm{~atm} \\
\mathrm{~T}: 25^{\circ} \mathrm{C} \\
\mathrm{t}: 5,10 \mathrm{~min} \\
\mathrm{Q}_{\mathrm{O} 3}: 0.5 \mathrm{~L} / \mathrm{min} \\
\lambda=254 \mathrm{~nm}\end{array}$ & $81.58 \%$ & [106] \\
\hline
\end{tabular}

Notes: $\mathrm{T}=$ temperature, $\mathrm{P}=$ pressure, $\mathrm{t}=$ time, $\mathrm{Q}=$ flow rate, $\mathrm{C}=$ concentration, $\lambda=$ wavelength.

\subsubsection{Advanced Oxidation Processes (AOPs)}

The advanced oxidation processes (AOPs) are based on the generation of a sufficient amount of reactive oxygen species, i.e., adsorbed oxygen species, superoxide, and hydroxyl radi-cals [107-109]. The hydroxyl radical is one of the most reactive free radicals and the strongest oxidant $[91,110,111]$. Therefore, AOPs were developed to overcome the limitations of ozone utilization. In this case, AOPs such as the $\mathrm{O}_{3} / \mathrm{UV}$ processes, $\mathrm{O}_{3} / \mathrm{H}_{2} \mathrm{O}_{2}$ processes, a combination of $\mathrm{O}_{3}$ with biological treatment, or other AOPs were investigated to overcome this issue. The catalytic ozonation process has been extensively studied among these technologies and was found to be a promising technique for effectively mineralizing organic contaminants to $\mathrm{CO}_{2}$ and $\mathrm{H}_{2} \mathrm{O}$ [89]. The outcomes of several studies on phenol removal using AOPs are presented in Table 11.

\section{$\mathrm{O}_{3} / \mathrm{UV}$ Process}

Photolysis of $\mathrm{O}_{3}$ by UV in the aqueous system forms hydroxyl radical, which can mineralize various types of pollutants into $\mathrm{CO}_{2}, \mathrm{H}_{2} \mathrm{O}$, or harmless products. Ozone has a molar absorption coefficient $(\varepsilon)$ of $2952 \mathrm{~mol}^{-1} \mathrm{dm}^{3} \mathrm{~cm}^{-1}$ at the wavelength of $254 \mathrm{~nm}$, which is sufficient to generate hydroxyl radical. Hence, the $\mathrm{O}_{3} / \mathrm{UV}$ process can increase the formation of hydroxyl radicals and then reduce organic pollutants. Although $\mathrm{O}_{3} / \mathrm{UV}$ treatment is a promising technology, further comprehensive understanding is needed especially in the reaction kinetics, decomposition pathways, by-products generation, and the toxicity of wastewater treated by the $\mathrm{O}_{3} / \mathrm{UV}$ process [106].

\section{$\mathrm{O}_{3} / \mathrm{H}_{2} \mathrm{O}_{2}$ Process}

Active free radicals such as hydroxyl radicals formed from the decomposition of $\mathrm{O}_{3}$ in an aqueous solution are non-selective so that they can oxidize almost all organic compounds. Unfortunately, the formation of hydroxyl radicals is very limited in neutral or acidic environments due to the relatively low stability of ozone molecules under these 
conditions. Therefore, the addition of $\mathrm{H}_{2} \mathrm{O}_{2}$ can increase the formation of hydroxyl radical to some extent and lead to a rapid transformation of $\mathrm{O}_{3}$. However, in the $\mathrm{O}_{3} / \mathrm{H}_{2} \mathrm{O}_{2}$ process, the increase in hydroxyl radical formation is limited like some other AOPs. As a result, the yield of hydroxyl radicals in this process is about $50 \%$ of the amount of $\mathrm{O}_{3}$ consumed (on a molar basis). In addition, $\mathrm{H}_{2} \mathrm{O}_{2}$ residues in the solution need to be destroyed before being discharged into the environment [89].

\section{$\mathrm{O}_{3} /$ Biological Treatment}

The presence of toxic or bio recalcitrant pollutants in the treated water, such as phenol, pesticides, pharmaceuticals, and other contaminants, is difficult to remove by conventional biological processes due to their toxicity and/or low biodegradability. Ozonation and AOPs are generally considered to be highly efficient processing technology for removing these recalcitrant pollutants from the water. Combining ozonation with biological treatment to reduce operating costs has also been widely investigated and developed [89].

Generally, ozonation/biological treatment innovations can be divided into two types. First, the use of ozonation is utilized as a pre-treatment, for example, ozone-biological activated carbon process, ozonation/batch aerobic biological system, ozonation/biological aeration filter. The second is employing ozonation as a post-treatment, for example, membrane bioreactor/ozonation, activated-sludge biological treatment/ozonation, and sequencing batch biofilm reactor/ozonation. Ozonation and ozone-based processes form intermediate products that are usually more readily biodegradable and eliminated by biological processes than their precursors. Therefore, pre-treated ozonation is suitable for application in water, which contains large amounts of inhibitory compounds that may be toxic to biological cultures [112].

\section{Catalytic Ozonation}

One of the main drawbacks of the ozonation process is that it produces toxic byproducts and cannot complete the mineralization of contaminants in water or wastewater treatments. Thus, the utilization of catalysts and ozone can be used simultaneously to overcome these limitations; this process is called catalytic ozonation. Catalytic ozonation is a potential way to reduce ozone consumption, increase selectivity and increase the reaction rate of contaminants [113]. The catalyst added to the ozonation reactor can increase the rate of $\mathrm{O}_{3}$ decomposition to produce more active free radicals, such as hydroxyl radicals. Operational cost in the catalytic ozonation process can be reduced since this process does not require other energy costs (such as $\mathrm{UV}$ ) or $\mathrm{pH}$ adjustments costs due to its effectiveness in a wide range of $\mathrm{pH}$ values. In addition, the catalytic ozonation process showed excellent performance for phenol degradation. Many catalysts have been used for this process, such as metal oxides, minerals, carbonaceous materials, and metals on catalyst supports [89].

In general, catalytic ozonation is divided into homogeneous catalytic ozonation and heterogeneous catalytic ozonation, as shown in Figure 16. Homogeneous catalytic ozonation is based on the activation of ozone by metal ions as a catalyst. In contrast, heterogeneous catalytic ozonation is based on the presence of heterogeneous catalysts such as metal oxides or metals on metal oxides supports, carbon, and mesoporous materials.

The homogeneous catalytic ozonation reactor only consists of two phases (gas for ozone and liquid for wastewater and catalyst). In comparison, a heterogeneous catalytic ozonation reactor consists of three phases (gas for ozone, liquid for wastewater, and solid for catalyst). Generally, experiments using ozone are produced by an ozone generator through converting oxygen or air. There are various types of reactors used in the catalytic ozonation process. Batch system reactors are most commonly used in laboratory-scale research, although this does not rule out continuous system reactors. Figure 17 shows the example of a series of catalytic ozonation reactor apparatus. 


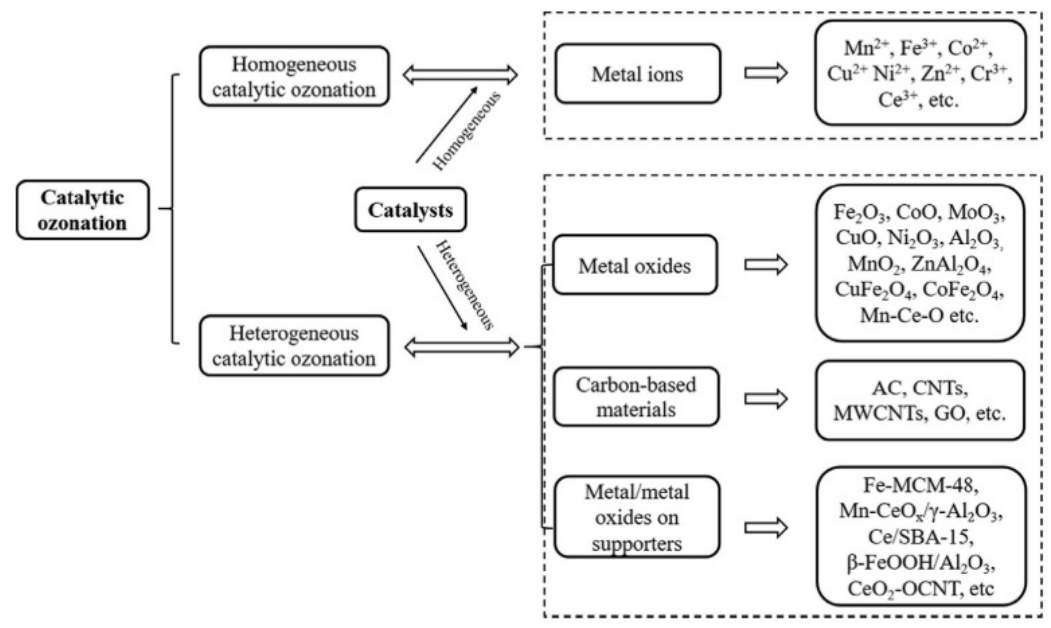

Figure 16. A variety of homogeneous and heterogeneous catalysts in the catalytic ozonation process. Reproduced from Ref. [89]. Copyright 2020 Elsevier.

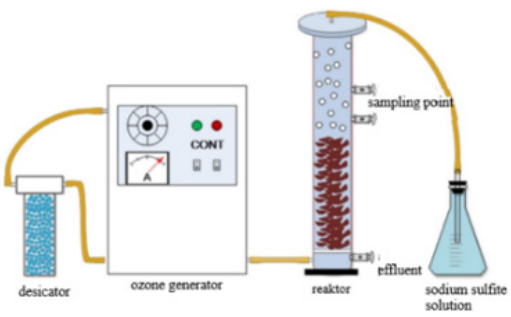

(a)

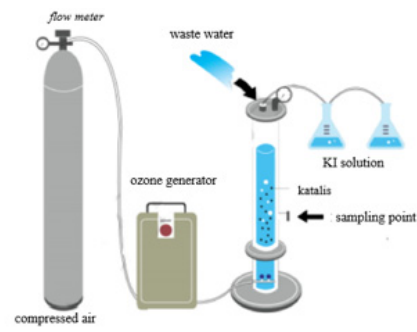

(b)
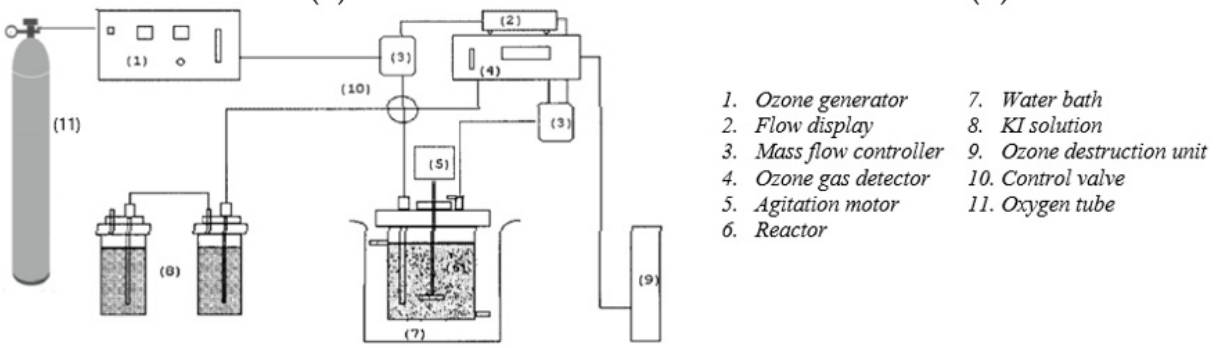

(c)

Figure 17. Catalytic ozonation reactor apparatus (a) Batch reactor; (b) semi-batch reactor; and (c) semi-batch stirred reactor. Reproduced from Refs. [105,106,109]. Copyright 2017 and 2018 Elsevier.

\section{Catalytic Ozonation Mechanisms}

\subsection{Homogeneous Catalytic Ozonation}

Homogeneous catalytic ozonation usually uses transition metal ions catalysts, such as $\mathrm{Fe}^{2+}, \mathrm{Mn}^{2+}, \mathrm{Ni}^{2+}, \mathrm{Co}^{2+}, \mathrm{Cd}^{2+}, \mathrm{Cu}^{2+}, \mathrm{Ag}^{+}, \mathrm{Cr}^{3+}$, and $\mathrm{Zn}^{2+}$. The mechanism of homogeneous catalytic ozonation in solutions can be explained by the fact that: (1) Metal ions initiate the ozone decomposition reaction by generating superoxide radicals $\left(\bullet \mathrm{O}_{2}^{-}\right) ;(2)$ The transfer of electrons from $\bullet \mathrm{O}_{2}{ }^{-}$molecules to $\mathrm{O}_{3}$ causes the formation of $\bullet \mathrm{O}_{3}{ }^{-}$; (3) Formation of hydroxyl radicals $(\bullet \mathrm{OH})$; (4) The formation of complexes between the catalyst and organics followed by a final oxidation reaction. However, it is important to note that the efficiency and the mechanism of homogeneous catalytic ozonation can also be influenced by several factors, including the $\mathrm{pH}$ of a solution, the types and concentration of metal ions, and organic pollutants $[89,91]$.

The mechanism of homogeneous catalytic ozonation is shown in Equations (15)-(22) as follows [114]:

$$
\mathrm{O}_{3}+\mathrm{OH}^{-} \rightarrow \mathrm{HO}_{2} \bullet+\mathrm{O}_{2}
$$




$$
\begin{gathered}
\mathrm{O}_{3}+\mathrm{H}_{2} \mathrm{O}^{-} \rightarrow \mathrm{HO}_{2} \bullet+\bullet \mathrm{O}_{3}^{-} \\
\mathrm{O}_{3}+\mathrm{In} \rightarrow \bullet \mathrm{O}_{3}{ }^{-}+\mathrm{ln}^{+} \\
\mathrm{HO}_{2} \bullet \bullet \bullet \mathrm{O}_{2}{ }^{-}+\mathrm{H}^{+} \\
\mathrm{O}_{3}+\bullet \mathrm{O}_{2}{ }^{-} \rightarrow \bullet \mathrm{O}_{3}{ }^{-}+\mathrm{O}_{2} \\
\bullet \mathrm{O}_{3}{ }^{-}+\mathrm{H}^{+} \rightarrow \mathrm{HO}_{3} \bullet \\
\mathrm{HO}_{3} \bullet \rightarrow \mathrm{HO} \bullet+\mathrm{O}_{2} \\
\mathrm{HO}_{3} \bullet+\mathrm{P} \rightarrow \text { end products }
\end{gathered}
$$

where $\ln$ is the initiator of ozone decomposition, and $\mathrm{P}$ is the scavenger of hydroxyl radicals.

The $\mathrm{Fe}^{2+} / \mathrm{O}_{3}$ system, which involves the direct reaction between $\mathrm{Fe}^{2+}$ and ozone, further generates hydroxyl radicals $(\bullet \mathrm{OH})$ as shown in Equations (23) and (24) [91]:

$$
\begin{gathered}
\mathrm{Fe}^{2+}+\mathrm{O}_{3} \rightarrow \mathrm{FeO}^{2+}+\mathrm{O}_{2} \\
\mathrm{FeO}^{2+}+\mathrm{H}_{2} \mathrm{O} \rightarrow \mathrm{Fe}^{3+}+\bullet \mathrm{OH}+\mathrm{OH}^{-}
\end{gathered}
$$

Excess metal ions will scavenge the resulting hydroxyl radicals, so optimization of the catalyst loading is also important for the catalytic ozonation process. The transition metal ions will be oxidized and eventually regenerated to their initial form, ensuring that the catalytic reaction can be recycled. Generally, the ozonation process strongly depends on the $\mathrm{pH}$ value of the solution. At $\mathrm{pH}<4$, direct ozonation will dominate the process while $\mathrm{pH}$ of

\begin{tabular}{|c|c|c|c|c|c|}
\hline Reactor & Catalyst & $\begin{array}{l}\text { Phenolic } \\
\text { Compound }\end{array}$ & $\begin{array}{l}\text { Operating } \\
\text { Conditions }\end{array}$ & $\begin{array}{c}\text { Efficiency of TOC } \\
\text { Removal }\end{array}$ & Ref. \\
\hline & $\mathrm{Mn}^{2+}-\mathrm{OCNTs}$ & & $\mathrm{T}: 25^{\circ} \mathrm{C}$ & $96 \%$ & \\
\hline $\begin{array}{l}\text { Cylindrical glass } \\
\text { reactor 5L }\end{array}$ & $\mathrm{Mn}^{2+}$ & Phenol & $\begin{array}{l}\mathrm{t}: 90 \mathrm{~min} \\
\mathrm{pH}: 3.5-7.8 \\
\mathrm{Q}_{\mathrm{O} 3}: 0.2 \mathrm{~L} / \mathrm{min} \\
\mathrm{C}_{\mathrm{O} 3}: 10 \mathrm{mg} / \mathrm{L} \\
\mathrm{C}_{\mathrm{Mn} 2+-\mathrm{OCNTs}}: \\
0.035 \mathrm{~g} / \mathrm{L}\end{array}$ & $70 \%$ & [102] \\
\hline
\end{tabular}
solution about 4-9, indirect ozonation or hydroxyl radicals will degrade pollutants. Metal

\begin{tabular}{|c|c|c|c|c|c|}
\hline \multirow{6}{*}{ Batch reactor } & $\mathrm{Pb}^{+}$ & \multirow{6}{*}{$\begin{array}{l}\text { 2-chloro phenol } \\
(2-\mathrm{CP})\end{array}$} & \multirow{6}{*}{$\begin{array}{l}\mathrm{T}: 25^{\circ} \mathrm{C} \\
\mathrm{t}: 60 \mathrm{~min} \\
\mathrm{pH}: 3 \\
\mathrm{Q}_{\mathrm{O} 3}: 18 \mathrm{mg} / \mathrm{min} \\
\mathrm{C}_{2-\mathrm{CP}}: 100 \mathrm{mg} / \mathrm{L} \\
\mathrm{C}_{\text {catalyst }}: 1 \mathrm{mg} / \mathrm{L}\end{array}$} & $13.2 \%$ & \multirow{6}{*}{ [115] } \\
\hline & $\mathrm{Cu}^{2+}$ & & & $14.3 \%$ & \\
\hline & $\mathrm{Zn}^{2+}$ & & & $14.3 \%$ & \\
\hline & $\mathrm{Fe}^{2+}$ & & & $20.4 \%$ & \\
\hline & $\mathrm{Ti}^{2+}$ & & & $20.8 \%$ & \\
\hline & $\mathrm{Mn}^{2+}$ & & & $29.9 \%$ & \\
\hline Batch reactor & $\mathrm{Ce}^{3+}$ & Phenol & $\begin{array}{l}\mathrm{T}: 25^{\circ} \mathrm{C} \\
\mathrm{t}: 180 \mathrm{~min} \\
\text { pH: n.a. } \\
\mathrm{Q}_{\mathrm{O} 3}: 0.1 \mathrm{~L} / \mathrm{min} \\
\mathrm{C}_{\text {phenol }}: 2.7 \mathrm{mM} \\
\mathrm{C}_{\mathrm{Ce} 3+}: 50 \mathrm{mM}\end{array}$ & $93 \%$ & [116] \\
\hline
\end{tabular}
ions increase the decomposition of $\mathrm{O}_{3}$ to generate hydroxyl radicals, which act as a vital compound for pollutants degradation. In catalytic ozonation, even though the solution has a low $\mathrm{pH}$ value (for example, $\mathrm{pH}=2$ ), hydroxyl radicals also play an important role in the degradation of pollutants [89]. Table 12 shows the comparison of various catalysts for phenol removal via the homogenous catalytic ozonation process.

Table 12. Comparison of the efficiency of total organic carbon (TOC) removal using various homogeneous catalysts for phenolic compounds removal from aqueous solution through the catalytic ozonation process. 
In some cases, homogeneous catalytic ozonation processes can effectively improve the removal of organic pollutants in water, but the addition of metal ions can result in secondary pollution. In addition, the homogeneous catalyst is often irrecoverable after the reaction has run to completion. Thus, this process is not efficient and economically viable if implemented on an industrial scale. Therefore, heterogeneous catalytic ozonation has received remarkable interest in recent years to overcome these issues.

\subsection{Heterogeneous Catalytic Ozonation}

Various types of heterogeneous catalysts in solid form with high stability and efficiency have been used in catalytic ozonation to overcome the shortcomings of homogeneous catalysts. The main catalysts commonly used for the process of heterogeneous catalytic ozonation are metal oxides $\left(\mathrm{MnO}_{2}, \mathrm{TiO}_{2}, \mathrm{Al}_{2} \mathrm{O}_{3}\right)$ and metals or metal oxides on supports (e.g., $\mathrm{Cu}-\mathrm{Al}_{2} \mathrm{O}_{3}, \mathrm{Cu}-\mathrm{TiO}_{2}, \mathrm{Ru}-\mathrm{CeO}_{2}, \mathrm{~V}-\mathrm{O} / \mathrm{TiO}_{2}, \mathrm{~V}-\mathrm{O} /$ silica gel, and $\mathrm{TiO}_{2} / \mathrm{Al}_{2} \mathrm{O}_{3}$, $\mathrm{Fe}_{2} \mathrm{O}_{3} / \mathrm{Al}_{2} \mathrm{O}_{3}$ ). The main catalytic activity is based on catalytic ozone decomposition to enhance the generation of hydroxyl radicals. Several factors that affect the efficiency of the catalytic ozonation process are the types of catalyst and its physiochemical properties, the pollutant target, the $\mathrm{pH}$ value of the solution that affects the surface active site properties, and ozone decomposition reactions in aqueous solution [89,91,117].

The heterogeneous catalytic ozonation system consists of three phases including gas (ozone gas), liquid (water), and solid (catalyst), which makes it complex. Catalysts provide reaction sites for the adsorption and catalysis process. Three possible situations (Figure 18) would occur in the heterogeneous catalytic ozonation system based on the interactions between the catalyst, ozone $\left(\mathrm{O}_{3}\right)$, and organic compounds [89]:

1. Catalytic adsorption of $\mathrm{O}_{3}$ and organic compounds then reacted.

2. Catalytic adsorption of $\mathrm{O}_{3}$ and then decomposed to produce free radicals, then the free radicals are reacted with organic compounds in bulk solution.

3. Catalytic adsorption of organic compounds, then, is attacked by $\mathrm{O}_{3}$ molecules or other reactive oxygen species.

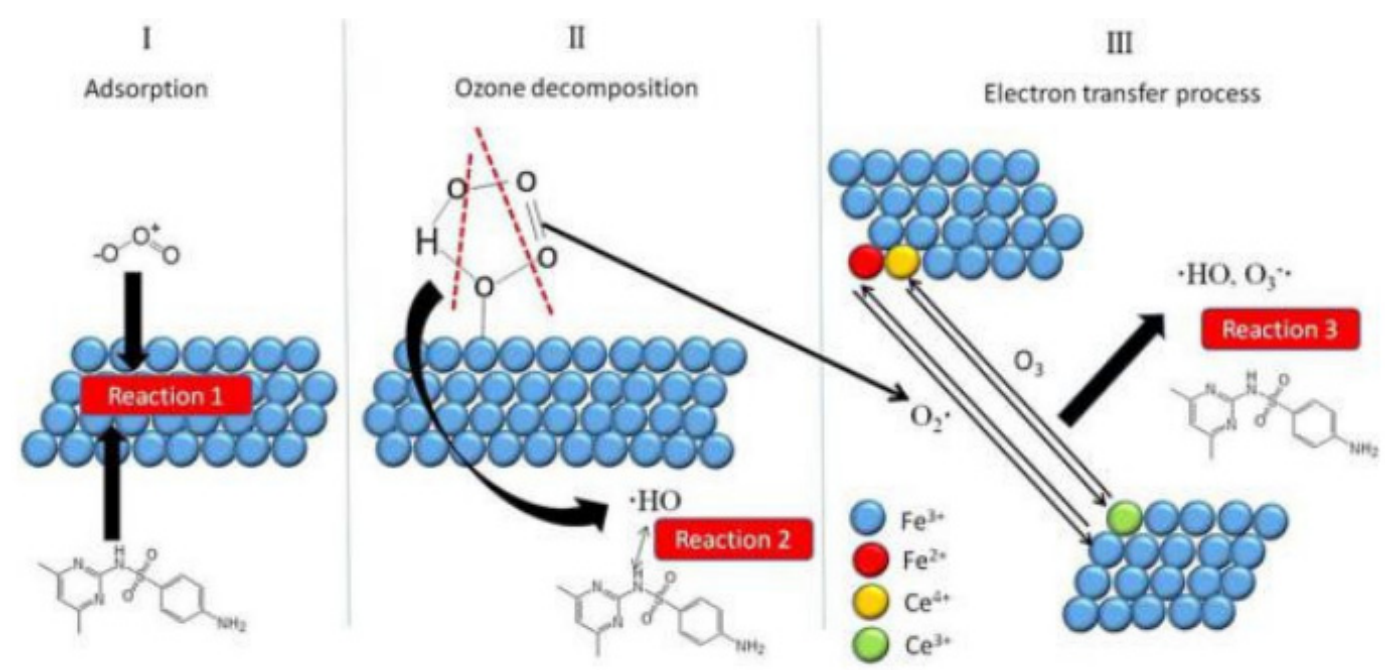

Figure 18. Schematic of possible mechanisms for heterogeneous catalytic ozonation. Reproduced from Ref. [118]. Copyright 2019 MDPI.

The mechanism of heterogeneous catalytic ozonation decomposition can be classi-fied based on the values of the $\mathrm{pH}$ range as follows [114]:

$\mathrm{pH} 2-6$ :

$$
\begin{gathered}
\mathrm{O}_{3}+\mathrm{S} \rightleftharpoons \mathrm{O}_{3}-\mathrm{S} \\
\mathrm{O}_{3}-\mathrm{S} \rightleftharpoons \mathrm{O}-\mathrm{S}+\mathrm{O}_{2} \\
\mathrm{O}_{3}+\mathrm{O}-\mathrm{S} \rightleftharpoons 2 \mathrm{O}_{2}+\mathrm{S}
\end{gathered}
$$




$$
\begin{gathered}
\mathrm{pH}>\text { 6: } \\
\mathrm{OH}^{-}+\mathrm{S} \rightleftharpoons \mathrm{OH}-\mathrm{S} \\
\mathrm{O}_{3}+\mathrm{OH}-\mathrm{S} \rightleftharpoons \bullet \mathrm{O}_{3}-\mathrm{S}+\mathrm{HO} \bullet \\
\bullet \mathrm{O}_{3}-\mathrm{S} \rightleftharpoons \bullet \mathrm{O}-\mathrm{S}+\mathrm{O}_{2} \\
\mathrm{O}_{3}+\bullet \mathrm{O}_{2}^{-} \rightarrow \bullet \mathrm{O}_{3}^{-}+\mathrm{O}_{2} \\
\bullet \mathrm{O}_{3}^{-}+\mathrm{H}^{+} \rightarrow \mathrm{HO}_{3} \bullet \\
\mathrm{HO}_{3} \bullet \rightarrow \mathrm{HO} \bullet+\mathrm{O}_{2} \\
\mathrm{HO}_{3} \bullet+\mathrm{P} \rightarrow \text { end products }
\end{gathered}
$$

where $S$ is the catalyst surface and $\mathrm{P}$ is the hydroxyl radical scavenger. The classification of the mechanism proposed above based on the $\mathrm{pH}$ value also depends on the type of catalyst used which also has the characteristic of surface acidity/basicity strength as reported by Malaika, et al. [119].

There are several considerations on the physical and chemical properties of metal oxides when selecting a catalyst. Physical properties including surface area, density, pore volume, porosity, pore size distribution, mechanical strength, purity, and commercial availability. Chemical properties are chemical stability and active surface sites such as Lewis acid sites, which are responsible for catalytic reactions. The catalytic properties of metal oxides are determined by their acidity and basicity. The number and the properties of the hydroxyl groups depend on the metal oxide and formed on the surface of the

\begin{tabular}{|c|c|c|c|c|c|}
\hline Reactor & Catalyst & $\begin{array}{l}\text { Phenolic } \\
\text { Compound }\end{array}$ & Operating Conditions & $\begin{array}{c}\text { Efficiency of } \\
\text { Removal }\end{array}$ & Ref. \\
\hline $\begin{array}{l}\text { Semi-batch stirred } \\
\text { reactor }\end{array}$ & $\gamma$-alumina & 2-chlorophenol & $\begin{array}{l}\mathrm{P}: 1 \mathrm{~atm} \\
\mathrm{~T}: 25^{\circ} \mathrm{C} \\
\mathrm{pH}: 9 \\
\text { t: } 60 \mathrm{~min} \\
\mathrm{Q}_{\mathrm{O} 3}: 18 \mathrm{mg} / \mathrm{min} \\
\mathrm{C}_{\text {phenol }}: 100 \mathrm{mg} / \mathrm{L} \\
\mathrm{m}_{\text {catalyst }}: 5 \mathrm{~g}\end{array}$ & $45.8 \%$ & [120] \\
\hline Fluid bed reactor & $\begin{array}{l}\text { Activated carbon } \\
\text { fiber }(\mathrm{ACF})\end{array}$ & Phenol & $\begin{array}{l}\text { P: } 1 \mathrm{~atm} \\
\mathrm{~T}: 25^{\circ} \mathrm{C} \\
\text { pH: } 6.1 \\
\text { t: } 10 \mathrm{~min} \\
\mathrm{Q}_{\mathrm{O} 2}: 5 \mathrm{~L} / \mathrm{min} \\
\mathrm{C}_{\mathrm{O} 3}: 9.8 \mathrm{mg} / \mathrm{L} \\
\mathrm{C}_{\text {phenol }}: 100-500 \mathrm{mg} / \mathrm{L} \\
\mathrm{m}_{\text {catalyst }}: 2 \mathrm{~g}\end{array}$ & $99.8 \%$ & [7] \\
\hline \multirow{4}{*}{$\begin{array}{l}\text { Semi-continuous } \\
\text { reactor }\end{array}$} & H-ZSM-5 (80) & \multirow{4}{*}{ Phenol } & P: $1 \mathrm{~atm}$ & $75.0 \%$ & \multirow{4}{*}{ [4] } \\
\hline & H-Beta & & T: $30^{\circ} \mathrm{C}$ & $60.0 \%$ & \\
\hline & H-USY & & $\mathrm{t}: 60 \mathrm{~min}$ & $58.0 \%$ & \\
\hline & H-Modernite & & $\begin{array}{l}\mathrm{Q}_{\mathrm{O} 3}: 10 \mathrm{~L} / \mathrm{min} \\
\mathrm{C}_{\text {phenol }}: 100 \mathrm{ppm} \\
\mathrm{m}_{\text {catalyst }}: 1 \mathrm{~g}\end{array}$ & $54.0 \%$ & \\
\hline
\end{tabular}
metal oxide behaves as Brönsted acid sites. The Lewis acid and base sites are located on the coordinated metal cations and unsaturated oxygen. The Brönsted and Lewis acid sites are considered to be the catalytic centers of metal oxides [91]. Table 13 shows the comparison of various catalysts via heterogeneous catalytic ozonation process for phenolic compounds removal.

Table 13. Comparison of the efficiency of phenolic compounds removal from aqueous solution using various heterogeneous catalysts via catalytic ozonation process. 
Table 13. Cont.

\begin{tabular}{|c|c|c|c|c|c|}
\hline Reactor & Catalyst & $\begin{array}{l}\text { Phenolic } \\
\text { Compound }\end{array}$ & Operating Conditions & $\begin{array}{l}\text { Efficiency of } \\
\text { Removal }\end{array}$ & Ref. \\
\hline $\begin{array}{l}\text { Semi-continuous } \\
\text { flow reactor }\end{array}$ & $\begin{array}{l}\mathrm{Co}_{3} \mathrm{O}_{4} \\
\text { Nanoparticles }\end{array}$ & Phenol & $\begin{array}{l}\mathrm{P}: 1 \mathrm{~atm} \\
\mathrm{~T}: 25^{\circ} \mathrm{C} \\
\mathrm{pH}: 6.3 \\
\mathrm{t}: 60 \mathrm{~min} \\
\mathrm{Q}_{\mathrm{O} 3}: 0.4 \mathrm{mg} / \mathrm{min} \\
\mathrm{C}_{\text {phenol }}: 100 \mathrm{mg} / \mathrm{L} \\
\mathrm{m}_{\text {catalyst }}: 0.5 \mathrm{~g}\end{array}$ & $82.6 \%$ & [6] \\
\hline $\begin{array}{l}\text { Well-mixed semi } \\
\text { batch reactor }\end{array}$ & $\mathrm{NiO} / \mathrm{Al}_{2} \mathrm{O}_{3}$ & $\begin{array}{l}2,4,6- \\
\text { Trichlorophenol } \\
\text { (TCP) }\end{array}$ & $\begin{array}{l}\mathrm{P}: 1 \mathrm{~atm} \\
\mathrm{~T}: 26-27{ }^{\circ} \mathrm{C} \\
\text { pH: } 4 \\
\text { t: } 40 \mathrm{~min} \\
\mathrm{C}_{\mathrm{O} 3}: 9.8 \mathrm{mg} / \mathrm{L} \\
\mathrm{C}_{\mathrm{TCP}}: 75 \mathrm{mg} / \mathrm{L} \\
\mathrm{C}_{\text {catalyst }}: 5 \mathrm{~g} / \mathrm{L}\end{array}$ & $83.4 \%$ & [121] \\
\hline $\begin{array}{l}\text { Rotating packed } \\
\text { bed reactor (RPB) }\end{array}$ & $\begin{array}{l}\mathrm{Fe}-\mathrm{Mn}-\mathrm{Cu} / \gamma- \\
\mathrm{Al}_{2} \mathrm{O}_{3} \\
\text { catalyst }\end{array}$ & Phenol & $\begin{array}{l}\text { P: } 1 \mathrm{~atm} \\
\text { T: } 25^{\circ} \mathrm{C} \\
\text { pH: } 6 \\
\text { t: } 30 \mathrm{~min} \\
\mathrm{Q}_{\mathrm{O} 3}: 1 \mathrm{~L} / \mathrm{min} \\
\mathrm{C}_{\text {phenol }}: 100-500 \mathrm{mg} / \mathrm{L} \\
\mathrm{m}_{\text {catalist }}: 40 \mathrm{~g}\end{array}$ & $96.4 \%$ & [122] \\
\hline Bubble reactor & Activated carbon & phenol & $\begin{array}{l}\text { P: } 1 \mathrm{~atm} \\
\text { T: } 25^{\circ} \mathrm{C} \\
\text { pH: } 7 \\
\text { t: } 5 \mathrm{~h} \\
\text { QO3 }: 3 \mathrm{~L} / \mathrm{min} \\
\mathrm{C}_{\text {phenol }}: 100-400 \mathrm{mg} / \mathrm{L} \\
\mathrm{C}_{\text {catalyst }}: 1 \mathrm{~g} / \mathrm{L}\end{array}$ & $51.5 \%$ & [123] \\
\hline
\end{tabular}

Notes: $\mathrm{P}=$ pressure, $\mathrm{T}=$ temperature, $\mathrm{t}=$ reaction time, $\mathrm{C}=$ concentration, $\mathrm{Q}=$ flow rate, $\mathrm{m}=$ mass.

5. Development of Catalysts for Phenolic Compounds Removal via Heterogeneous Catalytic Ozonation

\subsection{Metal-Based Catalyst}

Ma et al. investigated a pilot-scale study of heterogeneous catalytic ozonation under neutral $\mathrm{pH}$ using recycled waste iron shavings (zero valent iron, $\mathrm{ZVI}$ ) as a catalyst for the removal of organic pollutants from wastewater. The experiment was carried out using batch and continuous reactors. The catalytic ozonation performance in batch mode reduced COD from $133 \mathrm{mg} / \mathrm{L}$ to $65 \mathrm{mg} / \mathrm{L}$ in just $13 \mathrm{~min}$, corresponding to a COD removal efficiency of $51 \%$ when the ozone dose was $14.6 \mathrm{~g}-\mathrm{O}_{3} / \mathrm{min}$. On the other hand, the performance of catalytic ozonation in continuous mode reduced COD from $165 \mathrm{mg} / \mathrm{L}$ to $54 \mathrm{mg} / \mathrm{L}$ in $30 \mathrm{~min}$, corresponding to a COD removal efficiency of $67 \%$ when the ozone loading was $10.2 \mathrm{~g}-\mathrm{O}_{3} / \mathrm{min}$ and hydraulic retention time (HRT) of $30 \mathrm{~min}$ [5].

$\mathrm{Li}$ et al. evaluated the catalytic ozonation process in industrial wastewater treatment using a Fe-based catalyst prepared by immersing, soaking, and oxidizing iron shavings using $\mathrm{NaOH}, \mathrm{HCl}$, and $\mathrm{H}_{2} \mathrm{O}_{2}$, respectively. The experiment was carried out for $180 \mathrm{~min}$ at a pH of 6.81. The use of $200 \mathrm{~g} / \mathrm{L}$ of catalyst in batch mode resulted in an increase in TOC removal from industrial wastewater to $78.7 \%$, compared to $31.6 \%$ TOC removal by using ozonation alone (without catalyst [124].

\subsection{Metal Oxides-Based Catalysts}

Some metal oxides commonly used as catalysts in the catalytic ozonation process are $\mathrm{TiO}_{2}, \mathrm{MnO}_{2}$, and $\mathrm{Al}_{2} \mathrm{O}_{3}$. The $\mathrm{O}_{3} / \mathrm{TiO}_{2}$ system was efficient for oxalic acid degradation in water at acidic $\mathrm{pH}$. An increase in the rate of oxidation was obtained as a result of 
an increase in the concentration of ozone. However, the effect of the catalyst dose was increased to only $3 \mathrm{~g} / \mathrm{L}$. The effect of temperature is positive in the range of $10-20{ }^{\circ} \mathrm{C}$, and there is only a slight difference at higher temperatures $\left(40^{\circ} \mathrm{C}\right)$ [114].

$\mathrm{Ni}$ et al. [120] reported that an alumina-based $\left(\mathrm{Al}_{2} \mathrm{O}_{3}\right)$ catalyst was an effective catalyst for the catalytic ozonation of 2-chlorophenol. Compared with ozonation alone at neutral $\mathrm{pH}$, the efficiency of catalytic ozonation showed two-fold enhancement. At acidic $\mathrm{pH}$ values compared to ozonation alone, the catalytic ozonation process using $\mathrm{Al}_{2} \mathrm{O}_{3}$ as a catalyst has increased $83.7 \%$ of TOC degradation. However, at alkaline $\mathrm{pH}$, it only increased $17 \%$ of the catalytic efficiency of ozonation. This is mainly because, in an alkaline environment, oxidation with ozone is already strong.

Catalytic ozonation using $\mathrm{MnO}_{2}$ synthesized with cetyltrimethylammonium bromide and commercial $\mathrm{MnO}_{2}(0.1 \mathrm{~g} / \mathrm{L})$ as a catalyst increased the degradation of 4-nitrophenol (4-NP) $(100 \mathrm{mg} / \mathrm{L})$ with an ozone flow rate of $100 \mathrm{~mL} / \mathrm{min}$ and an initial concentration of $50 \mathrm{mg} / \mathrm{L}$ at an initial $\mathrm{pH}$ of 5.8-5.9, and the removal efficiencies of 4 -NP were $97 \%$ and $75 \%$ at $45 \mathrm{~min}$, respectively [125].

The mechanisms of catalytic ozonation by metal oxides summarized by Wang et al. [89] as shown in Figure 19 and Equations (35)-(39) as follows:

$$
\begin{aligned}
& \mathrm{O}_{3}+\mathrm{Me}-\mathrm{OH}_{2}{ }^{+} \rightarrow \mathrm{Me}-\mathrm{OH}^{+} \bullet+\mathrm{HO}_{3} \bullet \\
& 2 \mathrm{O}_{3}+\mathrm{Me}-\mathrm{OH} \rightarrow \mathrm{Me}-\mathrm{O}_{2}{ }^{-} \bullet+\mathrm{HO}_{3} \bullet+\mathrm{O}_{2} \\
& \mathrm{Me}-\mathrm{OH}^{+} \bullet+\mathrm{H}_{2} \mathrm{O} \rightarrow \mathrm{Me}-\mathrm{OH}_{2}+\bullet \mathrm{OH} \\
& \mathrm{Me}-\mathrm{O}_{2}{ }^{-} \bullet+\mathrm{O}_{3}+\mathrm{H}_{2} \mathrm{O} \rightarrow \mathrm{Me}-\mathrm{OH}+\mathrm{O}_{2}+\mathrm{HO}_{3} \bullet \\
& \mathrm{HO}_{3} \bullet \rightarrow \bullet \mathrm{OH}+\mathrm{O}_{2}
\end{aligned}
$$

where Me is attributed to metal or metal oxide surfaces. Initially, dissolved ozone $\left(\mathrm{O}_{3}\right)$ is transferred from the liquid bulk to the catalyst surface, then $\mathrm{O}_{3}$ and organic compounds are adsorbed onto the catalyst surface. After that, the radical reaction of the adsorbed $\mathrm{O}_{3}$ combined with the hydroxyl group bonded to metal/metal oxide surface (Me-OH) groups and at the surface-active sites (such as Lewis acid sites or alkaline sites) of the metal oxides started. The resulting free active species, such as $\bullet \mathrm{OH}$ and $\mathrm{HO}_{3} \bullet$, can then react with $\mathrm{O}_{3}$ to directly produce $\bullet \mathrm{OH}$ or directly attack and degrade organic pollutants.

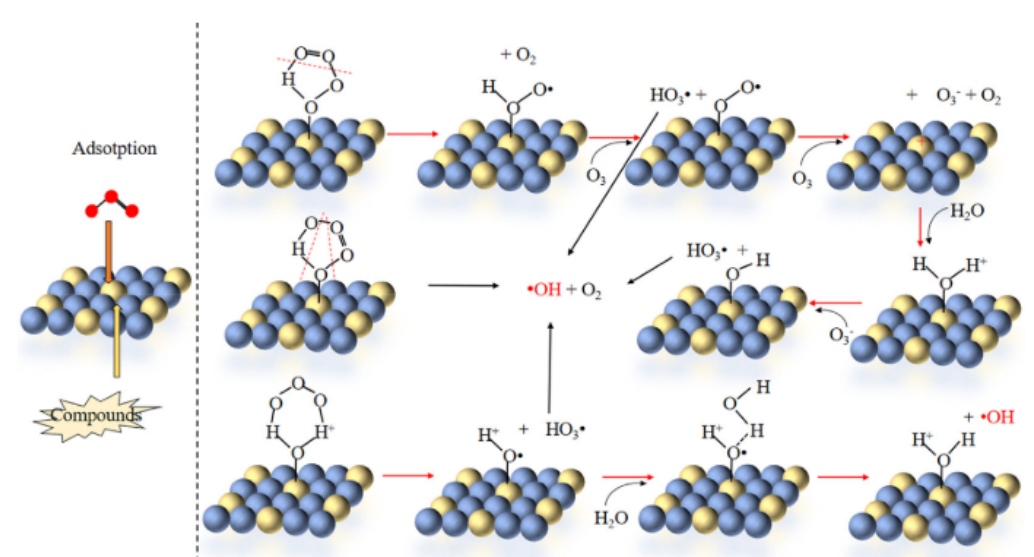

Figure 19. Possible catalytic mechanisms of metal oxides. Reproduced from Ref. [89]. Copyright 2020 Elsevier.

\subsection{Metal/Metal Oxides on Support-Based Catalysts}

Catalyst support, that is, metal oxides, plays an important role in supporting metalbased catalysts in the heterogeneous catalytic ozonation process by providing high specific surface area, good mechanical stability, and facilitating good charge transfer [93]. 
Hayek et al. [126] investigated the efficiency of the $\mathrm{Fe}$ (III) $/ \mathrm{Al}_{2} \mathrm{O}_{3} / \mathrm{O}_{3}$ system for removing phenol and its ozonation by-products from water. A significant decrease in TOC in aqueous solutions was obtained when catalytic ozonation was applied. The increased yield was explained by three pathways: (i) the adsorption of ozone and phenol on the alumina support, (ii) decomposition of hydrogen peroxide formed by the reaction of ozone molecules and unsaturated organics, and (iii) decomposition of ozone on the metal catalyst sites. The decompositions of hydrogen peroxide and ozone generate hydroxyl radicals, a strong oxidizing agent but less selective than ozone molecules.

Kruanak et al. [121] investigated the removal efficiency of 2,4,6-trichlorophenol (2,4,6-TCP) in synthetic wastewater using a catalytic ozonation process with nickel oxide doped on alumina support $\left(\mathrm{NiO} / \mathrm{Al}_{2} \mathrm{O}_{3}\right)$ as a catalyst. Catalytic ozonation occurred in a batch reactor for $40 \mathrm{~min}$ at room temperature $\left(25-27^{\circ} \mathrm{C}\right)$ with a catalyst loading of $5 \mathrm{~g} / \mathrm{L}$ in the $\mathrm{pH}$ range of 4-12. The removal efficiency of 2,4,6-TCP using catalytic ozonation with $\mathrm{NiO} / \mathrm{Al}_{2} \mathrm{O}_{3}$ catalyst was consistent at intervals of $84.30-86.58 \%$.

\subsection{Carbon-Based Catalysts}

Various carbon-based materials such as activated carbon, carbon nanotubes, and graphene have been used as catalysts in the catalytic ozonation process and showed good catalytic activity. For example, apart from acting as an adsorbent, activated carbon can also act as a catalyst in promoting ozone oxidation [89,91].

Moussavi et al. [127] investigated the ability of the presence of granular activated carbon (GAC) in an integrated catalytic ozonation/biological process to remove phenol from synthetic saline wastewater. The catalytic ozonation process could reduce the concentration of phenols and COD from about 1150 and $2600 \mathrm{mg} / \mathrm{L}$ to lower than 100 and $600 \mathrm{mg} / \mathrm{L}$ after $10 \mathrm{~min}$ of reaction time. In the effluent, after being treated in a bioreactor in a relatively short retention time to increase efficiency, resulting in the removal of phenol and COD was reduced to below $30 \mathrm{mg} / \mathrm{L}$.

\subsection{Mesoporous Catalysts}

The use of mesoporous materials has been widely used in various chemical fields and is found as an active catalyst for the catalytic ozonation process. Zhang et al. [128] reported that a mesoporous $\mathrm{MnO}_{2}$ prepared by nano casting method with SBA-15 as a template showed a higher adsorption capacity and TOC removal efficiency by eight- and two-fold compared to the control $\mathrm{MnO}_{2}$ catalyst, respectively. Hydroxyl radical was identified as the main reactive oxygen species during phenol removal via the catalytic ozonation process using mesoporous $\mathrm{MnO}_{2}$ with the yield of hydroxyl radical generation about two times enhanced compared with control $\mathrm{MnO}_{2}$ catalyst. In addition, Nawaz et al. [129] reported that mesoporous $\mathrm{Fe}_{3} \mathrm{O}_{4} / \mathrm{MnO}_{2}$ composite exhibited higher activity and stability compared to neat $\mathrm{Fe}_{3} \mathrm{O}_{4}$ and $\mathrm{MnO}_{2}$ in catalytic ozonation of chlorophenol with degradation efficiency of $99.5 \%, 75.8 \%$, and $89.4 \%$, respectively. This was due to $\mathrm{Fe}_{3} \mathrm{O}_{4} / \mathrm{MnO}_{2}$ had rich porosity and high surface area, which provides more active sites on the surface of the catalyst. In general, mesoporous materials only can be used towards small molecules since the ideal adsorption is only suitable for relatively small pore sizes $(\sim 4-5 \mathrm{~nm})$ which will play a significant active role in catalytic ozonation process [130]. However, the main drawbacks of mesoporous materials are difficulty in the preparation of well-ordered structure, scattered size distribution, and formation of stable colloidal suspension [131]. Thus, recently, porous materials, such as zeolites, have been widely developed on an industrial scale as catalysts and catalyst support for wide-range applications due to their good thermal and chemical stability, high surface area, and classified as a shape-selective catalyst resulting in excellent selectivity towards certain products. Therefore, the zeolitebased catalyst can be a promising catalyst candidate in catalytic ozonation to remove phenol or phenolic compounds. 


\section{Zeolite as Heterogeneous Catalyst for Phenol Removal Using Heterogeneous Catalytic Ozonation Process}

6.1. Zeolite Structures and General Mechanism of Phenol Removal Using Heterogeneous Catalytic Ozonation Process

Microporous aluminosilicates are the origin of zeolites, but today the word "zeolites" is no longer restricted to this kind of material. The main building blocks of zeolites are those of $\left[\mathrm{SiO}_{4}\right]^{4-}$ and $\left[\mathrm{AlO}_{4}\right]^{5-}$ tetrahedral, which are infinitely extended in a 3D network linked together by shared oxygen atoms. T-atom occupies a tetrahedral position in the tetrahedral units $\mathrm{TO}_{4}$ structure of zeolites (Figure 20) with shared oxygen vertices ( $\mathrm{T}$ represents $\mathrm{Si}^{4+}$ or $\mathrm{Al}^{3+}$ ion while the $\mathrm{O} 4$ represents each oxygen atom shared by two T atoms) [132].

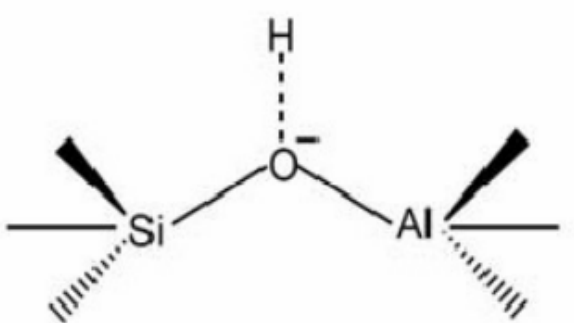

(a)

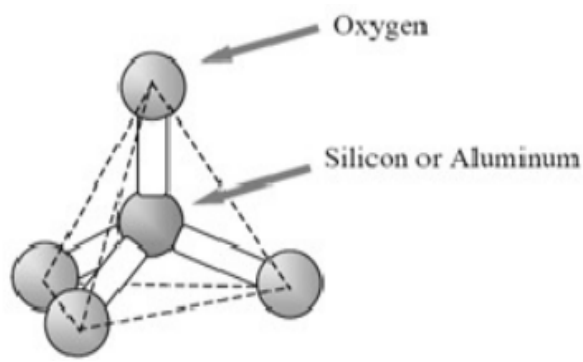

(b)

Figure 20. (a) Chemical structure of zeolites; (b) schematic of the building unit of zeolite structure. Repro-duced from Ref. [132].

Zeolite can act as a catalyst in the catalytic ozonation process, given the presence of several metal oxides in its composition. Zeolite contains $\mathrm{Al}_{2} \mathrm{O}_{3}$, which has been proven to remove organic compounds during the catalytic ozonation process [133]. Zeolites have excellent shape selectivity related to uniform pore size and dimension that allow molecular separation. In general, zeolites have a large specific surface area, high thermal and chemical stability, and controllable hydrophilicity/hydrophobicity properties. Therefore, zeolites can be applied in various processes such as catalysis, ion exchange, and molecular sieving [134].

Kitada et al. investigated the application of dealuminated $\mathrm{Y}$ zeolite as a catalyst in catalytic ozonation for phenol degradation and the removal of chemical oxygen demand (COD) in aqueous solutions [135]. Dealuminated $\mathrm{Y}$ zeolite has a Si/Al ratio of 3.83, a specific surface area of $532 \mathrm{~m}^{2} / \mathrm{g}$, and the particle sizes of $\mathrm{Y}$ zeolite are in the range of $0.5-1 \mathrm{~mm}$. The catalytic ozonation experiment was carried out in a semi-continuous flow mode at $293 \mathrm{~K}$ with an ozone flow rate of $0.30 \mathrm{mg} / \mathrm{min}$ and $0.5 \mathrm{~g}$ amount of dealuminated Y zeolite. The initial concentration of phenol was $100 \mathrm{mg} / \mathrm{L}$, and COD was $254 \mathrm{mg} / \mathrm{L}$ in the synthetic wastewater. After $45 \mathrm{~min}$, uncatalyzed ozonation exhibited a reduction of phenol concentration by up to $42.0 \mathrm{mg} / \mathrm{L}$ and $30.4 \%$, respectively. On the other hand, catalytic ozonation resulted in a COD removal of $47.5 \%$ with a phenol concentration degradation up to $12.5 \mathrm{mg} / \mathrm{L}$ It can be concluded that the COD removal efficiency increased 56.3\%, and the phenol removal efficiency increased 50.9\% compared to ozonation alone [136].

The interaction of the phenol molecules with zeolite structure depends on several factors. During catalytic ozonation phenol removal, zeolite mainly acted as adsorbents for both ozone gas and phenol. This action increases the probability of reactions between ozone and pollutant species. Ozone decomposition on the zeolite surface was considerably low except at high pH values. ZSM-5 has the ability to adsorb high concentrations of ozone. Several previous studies have shown that hydrophobic zeolite can adsorb pollutant and oxidant species on its surface to support better interactions. It is postulated that adsorption and surface reactions are significant pathways for phenol removal on the zeolite surfaces, as shown in Figure 21 [4]. 


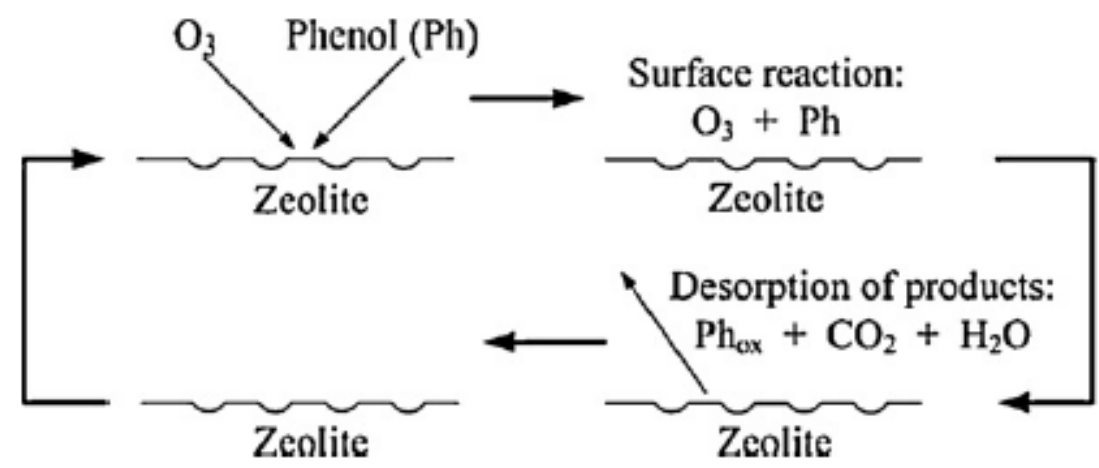

Figure 21. Schematic mechanism for removal of phenol during zeolite enhanced ozonation. Reproduced from Ref. [4]. Copyright 2010 Elsevier.

A schematic of the catalytic ozonation process using ZSM-5 zeolite as a catalyst is shown in Figure 22. Initially, this process proceeds through the initial adsorption of pollutants and ozone on the surface of the zeolite and is followed by a subsequent reaction, which results in the degradation of pollutants and the formation of oxidation by-products such as organic acids. The molecular reaction of ozone is noticeable at acidic $\mathrm{pH}$. However, at higher $\mathrm{pH}$ values, both ozone molecules and hydroxyl radicals (in the bulk solution) are capable of removing organic pollutants [137].

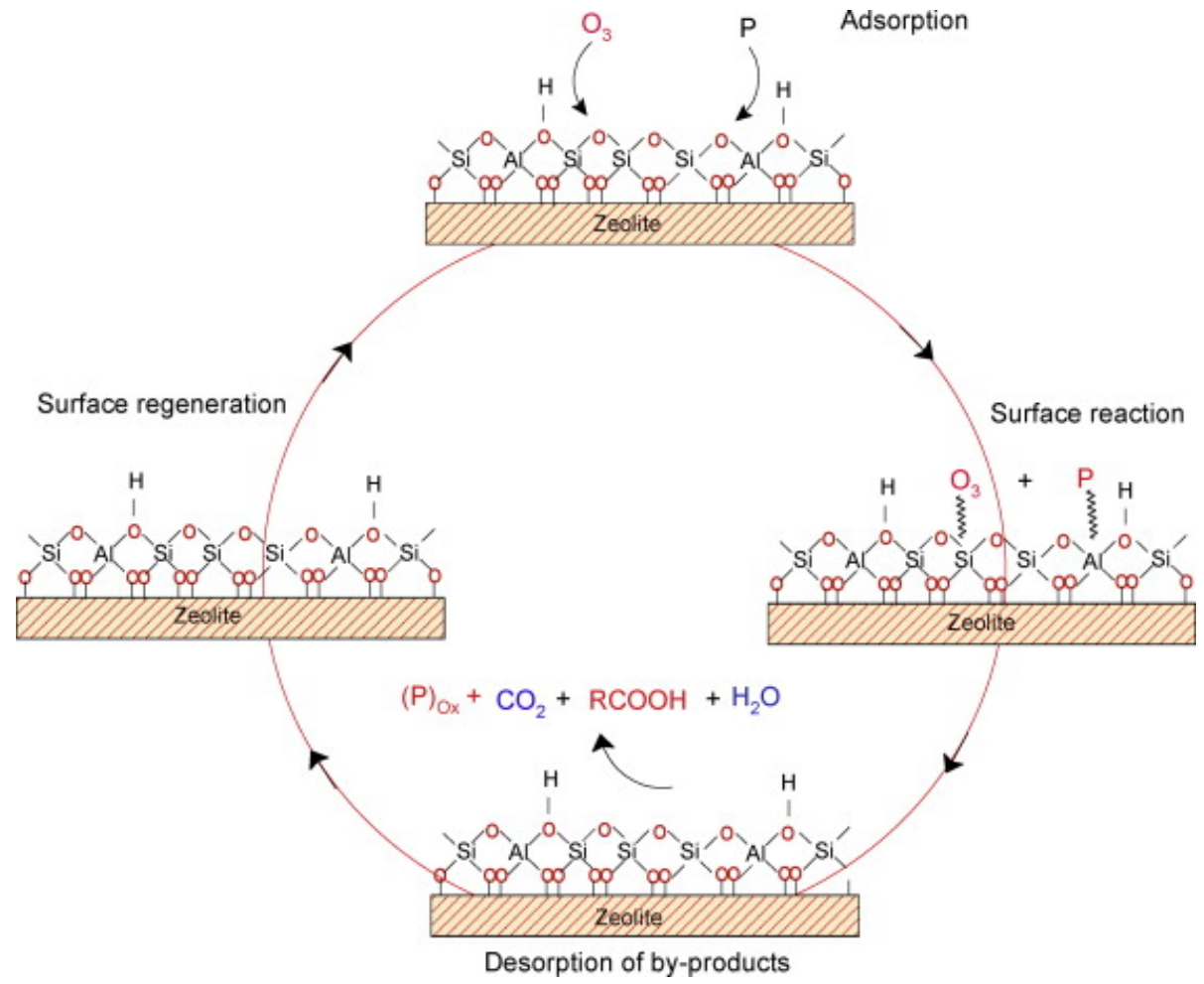

Figure 22. The schematic mechanism of catalytic ozonation on ZSM-5 zeolites ( $\mathrm{P}=$ pollutant). Reproduced from Ref. [137]. Copyright 2014 Elsevier.

Sano et al. investigated the catalytic ozonation process with $\mathrm{NaX}$ zeolite, metal-loaded $\mathrm{NaX}$ zeolite, zeolite $4 \mathrm{~A}$, and metal-loaded zeolites $4 \mathrm{~A}$ catalysts for phenol degradation in aqueous solution [94]. The experiment used a packed bed reactor with a constant temperature $\left(20^{\circ} \mathrm{C}\right)$, an ozone flow rate of $1500 \mathrm{~cm}^{3} / \mathrm{min}$, and an initial phenol concentration was $400 \mathrm{mg} / \mathrm{L}$. The results showed that the rate of phenol degradation through ozone reaction with a zeolite-based catalysts was higher than the rate of single ozonation. Furthermore, the degradation of phenol using a zeolite-4A-based catalyst was higher than that of the 
NaX-based zeolite catalyst. This might be due to the diameter of the inlet pore cage of A4 is $0.42 \mathrm{~nm}$, smaller than $\mathrm{NaX}(0.74 \mathrm{~nm})$.

The catalytic ozonation process using four zeolites in the H-form (HZSM-5, H-Beta, H-Mordenite, and H-USY) as catalysts and operating under different conditions for removal of phenol and COD was investigated by Amin et al. [4]. The process variables used were phenol concentration in solution, ozonation airflow rates, solution $\mathrm{pH}$, temperature, and reaction time. The combination of zeolite and ozone was able to remove phenol and COD more effectively compared to ozonation alone. Zeolites mainly act as adsorbents, providing a surface for the reaction between ozone and phenol. The adsorption capacity of zeolite decreases at higher $\mathrm{pH}$ due to the formation of hydroxyl radicals. The high ozonated airflow rates at room temperature were suitable for removing phenol and COD. HZSM$5(80)$ showed a phenol removal efficiency of $50.5 \%$ using an initial phenol concentration of $100 \mathrm{mg} / \mathrm{L}$. HZSM-5(80) was the best catalyst for phenol and COD removal among all catalysts used in the process. However, at a higher phenol concentration, H-USY showed a better catalytic performance.

Table 14 shows the various types of zeolite catalysts and actual operating conditions that greatly influence the efficiency of phenol removal through catalytic ozonation processes. The most influential operating conditions include: solution $\mathrm{pH}$, temperature, initial phenol concentration, ozone level, amount of catalyst, residence time, and the type of reactor used. The $\mathrm{pH}$ promotes phenol removal for all types of zeolites. Increasing the $\mathrm{pH}$ will reduce the adsorption capacity of phenol on the zeolite surface. On the other hand, increasing the $\mathrm{pH}$ of the solution increased the ozone adsorption and ozone decomposition on the zeolite surface. This condition increases the removal of phenol in the bulk phase due to the increased formation of hydroxyl radicals which are greater oxidants than ozone $[4,36]$.

Table 14. The effectiveness comparison of zeolites-based catalyst for phenol removal via catalytic ozonation process.

\begin{tabular}{|c|c|c|c|c|}
\hline Catalyst Zeolites & Operating Conditions & Reactor & Efficiency of Removal & Ref. \\
\hline Dealuminated Y-zeolite & $\begin{array}{l}\text { P: } 1 \mathrm{~atm} \\
\mathrm{~T}: 20{ }^{\circ} \mathrm{C} \\
\mathrm{C}_{\text {phenol }}: 100 \mathrm{mg} / \mathrm{L} \\
\mathrm{Q}_{\mathrm{O} 3}: 0.3 \mathrm{mg} / \mathrm{min} \\
\mathrm{C}_{\text {catalyst }}: 4.2 \mathrm{~g} / \mathrm{L} \\
\text { t: } 45 \mathrm{~min} \\
\text { no } \mathrm{pH} \text { adjustment }\end{array}$ & $\begin{array}{l}\text { Semi-continuous flow } \\
\text { stirred reactor }\end{array}$ & $50.9 \%$ & [136] \\
\hline Zeolite $\mathrm{NaX}$ & $\begin{array}{l}\text { P: } 1 \text { atm } \\
\text { T: } 20{ }^{\circ} \mathrm{C} \\
\mathrm{C}_{\text {phenol }}: 400 \mathrm{mg} / \mathrm{L} \\
\mathrm{Q}_{\text {air }}: 1.5 \mathrm{~L} / \mathrm{min} \\
\mathrm{m}_{\text {catalyst }}: \text { n.a. } \\
\text { t: } 30 \mathrm{~min} \\
\text { pH: } 6.7\end{array}$ & Batch reactor & $\sim 100 \%$ & [94] \\
\hline H-ZSM-5 & \multirow{4}{*}{$\begin{array}{l}\text { P: } 1 \text { atm } \\
\text { T: } 30^{\circ} \mathrm{C} \\
\mathrm{C}_{\text {phenol }}: 100 \mathrm{mg} / \mathrm{L} \\
\mathrm{Q}_{\text {air }}: 1 \mathrm{~L} / \mathrm{min} \\
\mathrm{m}_{\text {Catalyst }}: 1.0 \mathrm{~g} \\
\text { t: } 60 \mathrm{~min} \\
\mathrm{pH}: 9\end{array}$} & \multirow{4}{*}{$\begin{array}{l}\text { Semi-continuous } \\
\text { reactor }\end{array}$} & $75.0 \%$ & \multirow{4}{*}{ [4] } \\
\hline H-Beta & & & $60.0 \%$ & \\
\hline H-USY & & & $58.0 \%$ & \\
\hline H-Modernite & & & $54.0 \%$ & \\
\hline
\end{tabular}

Notes: $\mathrm{P}=$ pressure, $\mathrm{T}=$ temperature, $\mathrm{t}=$ reaction time, $\mathrm{C}=$ concentration, $\mathrm{Q}=$ flow rate, $\mathrm{m}=$ mass.

The reaction between pollutants and ozone on the zeolite surface increases with increasing temperature. However, high temperature involves a sharp reduction in ozone dissolution [138]. The non-catalytic and catalytic ozonation removal performance increased with increasing the initial concentration of phenol. In other words, the phenol removal increases in the bulk phase. Increasing the amount of catalyst, ozone level and residence time 
will also enhance the phenol removal through the catalytic ozonation process. The effect of different zeolites related to the characteristics of each zeolite, in particular the structure, surface area, pore size diameter, hydrophobicity must be considered to achieve optimum phenol removal efficiency.

\subsection{Effect of Zeolite Characteristics on Phenol Removal Using Heterogeneous Catalytic Ozonation Process}

During phenol ozonation, zeolite mainly acted as an adsorbent for ozone gas and phenol. The ability of zeolites to adsorb phenolic compounds is influenced by structure, surface area, pore size diameter, hydrophobicity, etc. The adsorption properties of a zeolite and its ability to act as a molecular sieve and catalyst are affected by the size and shape of the pores present in the zeolite framework. Zeolite is a size-selective adsorbent: the adsorbed molecules must be smaller than the pore size of the adsorbent. Pollutant molecules with a size larger than the zeolite pore opening can only be adsorbed on the outer surface of the zeolite, and in this case, the adsorption capacity is greatly decreased. The type of pore opening system in the zeolite framework affects the catalytic process and its adsorption and is currently classified into three types: (i) 8 member rings (small pore size zeolite), for example, zeolite A, (ii) 10 member rings (medium pore size zeolite), for example, zeolite ZSM-5, (iii) 12 member ring (large pore size zeolite), for example, zeolites $X$ and $Y[34,127]$. To remove phenol from the solution, one of the main characteristics of zeolites that can be used as an ideal catalyst must have a pore size that matches the size of the phenol compound. Since phenol has a diameter of about $4.2 \AA$, the range of ideal pore diameter of zeolites is about 4.2-8.0 ̊. Several candidates for zeolite-based catalysts that fulfill these requirements are summarized in Table 15.

Table 15. Type of zeolites materials with their corresponding limiting rings, ring members, and dimensional.

\begin{tabular}{|c|c|c|c|c|c|}
\hline Code & Materials & Limiting Rings (Å) & Member of Rings & Dimensional & Ref. \\
\hline $\mathrm{BOF}$ & UCSB-15GaGe & $5.2 \times 5.4$ & 10 & $1 \mathrm{D}$ & [139] \\
\hline $\mathrm{CON}$ & CIT-1 & $4.5 \times 5.1$ & 10 & $3 \mathrm{D}$ & [140] \\
\hline CSV & CIT-7 & $5.0 \times 6.2$ & 10 & $2 \mathrm{D}$ & [141] \\
\hline FER & ZSM-35 & $4.2 \times 5.4$ & 10 & $2 \mathrm{D}$ & [142] \\
\hline ITH & IM-7 & $\begin{array}{l}4.8 \times 5.3 \\
4.8 \times 5.1 \\
\end{array}$ & 10 & $3 \mathrm{D}$ & [143] \\
\hline ITR & ITQ-34 & $\begin{array}{l}4.8 \times 6.0 \\
4.7 \times 5.8\end{array}$ & 10 & $3 \mathrm{D}$ & [144] \\
\hline IWR & ITQ-24 & $4.6 \times 5.3$ & 10 & $3 \mathrm{D}$ & [145] \\
\hline IWW & ITQ-22 & $4.9 \times 4.9$ & 10 & $3 \mathrm{D}$ & [145] \\
\hline JST & GaGeO-CJ63 & $5.6 \times 5.6$ & 10 & $3 \mathrm{D}$ & [139] \\
\hline MEL & TS-2 & $5.3 \times 5.4$ & 10 & $3 \mathrm{D}$ & [146] \\
\hline MFI & ZSM-5 & $\begin{array}{l}5.1 \times 5.5 \\
5.3 \times 5.6\end{array}$ & 10 & $3 \mathrm{D}$ & [147] \\
\hline MFS & ZSM-57 & $5.1 \times 5.4$ & 10 & $2 \mathrm{D}$ & [148] \\
\hline MSE & MCM-68 & $\begin{array}{l}5.2 \times 5.8 \\
5.2 \times 5.2\end{array}$ & 10 & $3 \mathrm{D}$ & [149] \\
\hline MTT & ZSM-23 & $4.5 \times 5.2$ & 10 & $1 \mathrm{D}$ & [150] \\
\hline NES & NU-87 & $4.8 \times 5.7$ & 10 & $2 \mathrm{D}$ & [151] \\
\hline $\mathrm{OKO}$ & COK-14 & $4.7 \times 6.1$ & 10 & $2 \mathrm{D}$ & [145] \\
\hline PSI & PST-6 & $5.0 \times 5.6$ & 10 & $1 \mathrm{D}$ & [152] \\
\hline PUN & PKU-9 & $4.7 \times 7.0$ & 10 & $3 \mathrm{D}$ & [153] \\
\hline
\end{tabular}


Table 15. Cont.

\begin{tabular}{|c|c|c|c|c|c|}
\hline Code & Materials & Limiting Rings (Å) & Member of Rings & Dimensional & Ref. \\
\hline PWW & PST-22 & $5.2 \times 6.0$ & 10 & $2 \mathrm{D}$ & [154] \\
\hline SEW & SSZ-82 & $4.9 \times 5.1$ & 10 & $2 \mathrm{D}$ & [155] \\
\hline SFF & SSZ-44 & $5.4 \times 5.7$ & 10 & 1D & [156] \\
\hline SFG & SSZ-58 & $\begin{array}{l}5.2 \times 5.7 \\
4.8 \times 5.7\end{array}$ & 10 & $2 \mathrm{D}$ & [157] \\
\hline SFS & SSZ-56 & $5.1 \times 5.5$ & 10 & $2 \mathrm{D}$ & [158] \\
\hline STF & SSZ-35 & $5.4 \times 5.7$ & 10 & 1D & [156] \\
\hline STI & TNU-10 & $4.7 \times 5.0$ & 10 & $2 \mathrm{D}$ & [159] \\
\hline STW & SU-32 & $6.0 \times 6.0$ & 10 & $3 \mathrm{D}$ & [160] \\
\hline -SVR & SSZ-74 & $\begin{array}{l}5.5 \times 5.7 \\
5.2 \times 5.9 \\
5.2 \times 5.6\end{array}$ & 10 & $3 \mathrm{D}$ & [161] \\
\hline TON & Tetha-1 & $4.6 \times 5.7$ & 10 & 1D & [162] \\
\hline UOV & IM-17 & $4.7 \times 5.9$ & 10 & $3 \mathrm{D}$ & [163] \\
\hline
\end{tabular}

It has been reported by Amin et al. [4] that at high phenol concentration, surface area, and pore volume of zeolite were the dominant parameters due to high diffusion of phenol molecules and high collision while at low phenol concentration, the hydrophobic surface became the main parameter and exhibited better catalytic performance. In zeolites, the hydrophobicity depends on the $\mathrm{Si} / \mathrm{Al}$ framework. When the $\mathrm{Si} / \mathrm{Al}$ molar ratio increases, the hydrophilic properties will decrease or get closer to the hydrophobic characteristics. Therefore, decreasing the amount of aluminum framework will linearly decrease the water adsorption capacity. However, BEA and MFI, which possess a high $\mathrm{Si} / \mathrm{Al}$ ratio, were more efficient for phenol removal [36].

$\mathrm{Si} / \mathrm{Al}$ ratio also affects the acidity of zeolite. The lower the $\mathrm{Si} / \mathrm{Al}$ ratio, the more acidic the zeolites are. The strength of Lewis acidity in zeolites is highly dependent on crystallinity. After the crystal collapses, Lewis acidity decreased both in strength and quantity [164]. Observations in favor of acidity correspond to high steaming temperatures, which increases the initial selectivity to phenol, prolongs service life, and reduces side reactions at the same time [11]. The use of zeolite as a catalyst is based on the catalytic properties resulting from the combination of the intrinsic properties contained in zeolites. These properties are responsible for its overall catalytic behavior. The production of active sites in zeolite-based catalysts, also known as Bronsted sites, results from the exchange of cations with ammonium hydroxide and calcination is one of the most important steps. These sites are referred to as linking hydroxyl are formed at each oxygen bridge site near the Si-O-Al grouping, where protons represent cations that neutralize the negative charge. The Bronsted site is the main reason why zeolites are used as catalysts in several industries, and this is the result of the formation of the hydroxyl groups in the pore structure of zeolite which has a high electrostatic field that attracts organic molecular reactants resulting in chemical bonds [132,165].

Table 16 shows the characteristics of zeolite used as a catalyst in the catalytic ozonation process to remove phenol. Although zeolite has good properties as an adsorbent, the efficiency of phenol removal also depends on the operating conditions. Typically, zeolite crystal size is about $1 \mu \mathrm{m}$. The smaller the zeolite crystal size will produce a larger surface area compared to the zeolites that have a larger crystal size [166]. With a large surface area and short diffusion path length, nano-sized zeolites provide an active site that is more accessible to the reactants [11]. Based on Table 16, the highest efficiency of phenol removal can be achieved when it has the lowest value of $\mathrm{Si} / \mathrm{Al}$ ratio and three-dimensional structures with 12 member rings. In contrast, the highest surface area is not linearly related to the 
resulting phenol removal efficiency Thus, overall zeolite characteristics including specific surface area, $\mathrm{Si} / \mathrm{Al}$ ratio, hydrophilicity, acidity strength, porosity, shape and dimension must be considered to understand the physiochemical properties-activity relationship. In order to achieve the desired physiochemical properties of zeolite, selection of synthesis method is crucial. Therefore, many researchers are developing nano-sized zeolites with various synthesis methods.

Table 16. Comparison of zeolite characteristics on phenol removal efficiency using catalytic ozonation process.

\begin{tabular}{|c|c|c|c|c|c|c|c|c|}
\hline $\begin{array}{l}\text { Catalyst } \\
\text { Zeolites }\end{array}$ & Framework & $\begin{array}{l}\text { Limiting } \\
\text { Rings (A)) }\end{array}$ & $\begin{array}{c}\text { Number of } \\
\text { Rings }\end{array}$ & Dimensional & Si/Al & $\begin{array}{c}\text { Surface } \\
\text { Area } \\
\left(\mathrm{m}^{2} / \mathrm{g}\right)\end{array}$ & $\begin{array}{l}\text { Efficiency } \\
\text { of Phenol } \\
\text { Removal }\end{array}$ & Ref. \\
\hline $\begin{array}{l}\text { Dealuminated } \\
\text { Y-zeolite }\end{array}$ & FAU & $7.4 \times 7.4$ & 12 & 3 & 3.83 & 532 & $50.9 \%$ & [136] \\
\hline Zeolite $\mathrm{NaX}$ & FAU & $7.4 \times 7.4$ & 12 & 3 & 1.16 & 476 & $\sim 100 \%$ & [94] \\
\hline H-ZSM-5 & MFI & $\begin{array}{l}5.1 \times 5.5 \\
5.3 \times 5.6\end{array}$ & 10 & 3 & 80 & 339 & $75.0 \%$ & \multirow{4}{*}[4]{} \\
\hline H-Beta & BEA & $\begin{array}{l}6.6 \times 6.7 \\
5.6 \times 5.6\end{array}$ & 12 & 3 & 25 & 501 & $60.0 \%$ & \\
\hline H-USY & FAU & $7.4 \times 7.4$ & 12 & 3 & 30 & 743 & $58.0 \%$ & \\
\hline H-Modernite & MOR & $\begin{array}{l}7.0 \times 6.5 \\
5.7 \times 2.6\end{array}$ & 12 & 2 & 20 & 481 & $54.0 \%$ & \\
\hline
\end{tabular}

6.3. Effect of Synthesis Method on Physiochemical Characteristics of Zeolite and Phenol Removal Using Heterogeneous Catalytic Ozonation Process

In order to exhibit a good impact in the catalytic ozonation process, zeolite must provide excellent catalytic properties. There are several characteristics of zeolites that are influenced by molar composition of zeolite precursor, duration, and temperature of the synthesis during synthesis process, namely the size and $\mathrm{Si} / \mathrm{Al}$ ratio of zeolite. For zeolite structure, organic structure directing agent (OSDA) has an important role, but currently synthetic zeolites have been developed without OSDA [167], at low pH in fluoride media [168], and at low operation temperature [169]. Therefore, it is important to study the effect of the synthetic method on the physiochemical characteristics and catalytic activity of phenolic compounds removal using zeolite-based catalyst.

In general, the most commonly used method for synthesis of zeolites catalysts is attained through the sol-gel process. Initially, it produces an amorphous gel with a small core with interactions between aluminate and silicate or silica sol. In general, the starting materials used for the synthesis of zeolites are metal salts (metal aluminates and metal silicates or silica sol) or metal alkoxides. Metal alkoxides are sometimes used to enhance the self-assembling capability since their organic components can be incorporated in micelles. Its hydrolytic inertness increases the size of the organic components (steric effect) and the number of alcohol groups in the ligand (chelate or cage effect). Additional hydrothermal treatment is required to obtain the crystalline phase. This treatment can be conducted using conventional hydrothermal, microwave heating, or ultrafast synthesis [170,171]. In hydrothermal treatment, the core grows into smaller crystals around the template. Then it becomes a larger crystal. Holding the reaction in the first step as it grows into small crystals gives small particles more surface area resulting in more catalytic activity [172]. Recently, zeolite synthesis method has been developed without a hydrothermal process. Table 17 presents the comparison of various zeolite synthesis methods on phenol removal efficiency and physiochemical characteristic of zeolites. Further research related to the use of zeolite-based catalysts as one of the promising catalyst candidates in removing phenolicbased waste by using heterogeneous catalytic ozonation still need to be developed. 
Table 17. Comparison of various zeolites synthesis methods on physiochemical characteristics and the efficiency of phenol removal.

\begin{tabular}{|c|c|c|c|c|c|c|c|c|}
\hline \multirow[b]{2}{*}{ Method } & \multirow[b]{2}{*}{$\begin{array}{l}\text { Precursors/Synthesis } \\
\text { Operating Condition }\end{array}$} & \multirow[b]{2}{*}{$\begin{array}{l}\text { Zeolite } \\
\text { Types }\end{array}$} & \multicolumn{4}{|c|}{ Zeolite characteristics } & \multirow{2}{*}{$\begin{array}{l}\text { Efficiency of } \\
\text { Phenol } \\
\text { Removal }\end{array}$} & \multirow[b]{2}{*}{ Ref. } \\
\hline & & & $\begin{array}{l}\text { Specific Surface } \\
\text { Area }\left(\mathrm{m}^{2} / \mathrm{g}\right)\end{array}$ & $\begin{array}{l}\text { Si/Al } \\
\text { Ratio }\end{array}$ & $\begin{array}{l}\text { Pore Diameter } \\
(\mathrm{nm})\end{array}$ & $\begin{array}{c}\text { Particle Size } \\
(\mu \mathrm{m})\end{array}$ & & \\
\hline \multirow{6}{*}{$\begin{array}{l}\text { Calcination } \\
\text { of commercial } \\
\text { zeolite }\end{array}$} & \multirow{6}{*}{$\begin{array}{l}\text { Commercial zeolites } / \\
\mathrm{T}=450-500^{\circ} \mathrm{C}\end{array}$} & $\begin{array}{l}\text { H-ZSM- } \\
5\end{array}$ & 339 & 80 & 0.51 & $<100$ & $75 \%$ & \multirow{4}{*}{ [4] } \\
\hline & & H-USY & 743 & 30 & 0.74 & $<100$ & $58 \%$ & \\
\hline & & $\begin{array}{c}\mathrm{H}- \\
\text { Modernite }\end{array}$ & 481 & 20 & 0.70 & $<100$ & $54 \%$ & \\
\hline & & H-Beta & 501 & 25 & 0.67 & $<100$ & $60 \%$ & \\
\hline & & $\mathrm{NaX}$ & 476 & 1.12 & 0.74 & $1400-2360$ & $\sim 100 \%$ & \multirow{2}{*}{ [94] } \\
\hline & & $4 \mathrm{~A}$ & 12 & 0.99 & 0.42 & $1400-2360$ & $\sim 100 \%$ & \\
\hline $\begin{array}{l}\text { Dealumination } \\
\text { of commercial } \\
\text { zeolite by } \\
\text { water vapor }\end{array}$ & Commercial Zeolite Y & $\begin{array}{l}\text { Dealuminated } \\
\text { Y-zeolite }\end{array}$ & 532 & 3.83 & 0.74 & $0.5-1.0$ & $51 \%$ & [136] \\
\hline $\begin{array}{l}\text { Sieved and } \\
\text { crushed of } \\
\text { commercial } \\
\text { zeolite }\end{array}$ & Commercial zeolite & $\begin{array}{l}\text { Natural } \\
\text { zeolite }\end{array}$ & 13.7 & 5.63 & n.a. & n.a. & $<50 \%$ & [173] \\
\hline \multirow{2}{*}{ Hydrothermal } & $\begin{array}{c}60 \mathrm{SiO}_{2}: 1 \mathrm{Al}_{2} \mathrm{O}_{3}: 15 \\
\text { TPAOH: } 5 \mathrm{Na}_{2} \mathrm{O}: 500 \\
\mathrm{H}_{2} \mathrm{O} / \mathrm{T}: 170{ }^{\circ} \mathrm{C} \\
\text { t: } 24 \mathrm{~h}\end{array}$ & ZSM-5 & 310 & 45 & n.a. & $\sim 0.1$ & n.a. & [174] \\
\hline & $\begin{array}{c}\mathrm{Na}_{2} \mathrm{O}: \mathrm{Al}_{2} \mathrm{O}_{3}: 20 \mathrm{SiO}_{2}: \\
\text { 8TMCAH: } 448.5 \mathrm{H}_{2} \mathrm{O} / \mathrm{T}: \\
160{ }^{\circ} \mathrm{C} \\
\text { t: } 144 \mathrm{~h}\end{array}$ & ZSM-35 & 296 & 7.6 & n.a. & $\sim 0.1$ & n.a. & [175] \\
\hline \multirow[t]{2}{*}{ Microwave } & $\begin{array}{c}\text { 1TEOS: } 0.22 \mathrm{NaCl} \\
0.19 \mathrm{TPAOH}: \\
0.023 \mathrm{NaAlO}_{2}: \\
178 \mathrm{H}_{2} \mathrm{O} / \mathrm{T}: 120^{\circ} \mathrm{C} \\
\text { t: } 3 \mathrm{~h} \\
\text { Power: } 250-400 \mathrm{~W}\end{array}$ & ZSM-5 & 19.8 & n.a. & n.a. & $0.34-0.44$ & n.a. & [176] \\
\hline & $\begin{array}{c}\text { 4.0 } \mathrm{Na}_{2} \mathrm{O}: 1 \mathrm{Al}_{2} \mathrm{O}_{3}: 20 \mathrm{SiO}_{2}: \\
900 \mathrm{H}_{2} \mathrm{O} / \mathrm{T}: 180{ }^{\circ} \mathrm{C} \\
\text { t: } 5 \mathrm{~h} \\
\text { Power: } 800 \mathrm{~W}\end{array}$ & ZSM-35 & n.a. & 17 & n.a. & $0.4-3.0$ & n.a. & [177] \\
\hline \multirow{3}{*}{$\begin{array}{l}\text { Ultrafast } \\
\text { synthesis }\end{array}$} & $\begin{array}{c}50 \mathrm{NaOH} \mathrm{Al}_{2} \mathrm{O}_{3}: 300 \\
\mathrm{SiO}_{2}: 20 \mathrm{TPAOH}: 2300 \\
\mathrm{H}_{2} \mathrm{O} / \mathrm{T}: 370^{\circ} \mathrm{C} \\
\text { t: } 6 \mathrm{~s}\end{array}$ & ZSM-5 & n.a. & 105 & n.a. & 0.2 & n.a. & {$[170]$} \\
\hline & $\begin{array}{c}\text { 0.1-0.15TEAOH: } \\
0.2-0.6 \mathrm{NaOH} \\
0.017-0.031 \mathrm{Al}_{2} \mathrm{O}_{3}: \\
1.0 \mathrm{SiO}_{2}: 18 \mathrm{H}_{2} \mathrm{O} / \mathrm{T}: 210{ }^{\circ} \mathrm{C} \\
\text { t: } 30 \mathrm{~min}\end{array}$ & ${ }^{*} \mathrm{BEA}$ & n.a. & 45.4 & 0.67 & 0.4 & n.a. & [178] \\
\hline & $\begin{array}{c}\text { 1.0 } \mathrm{Al}_{2} \mathrm{O}_{3}: 1.2 \mathrm{P}_{2} \mathrm{O}_{5}: \\
\text { 2.0TEAOH: } 0.6 \mathrm{SiO}_{2} \text { : } \\
40 \mathrm{H}_{2} \mathrm{O}\end{array}$ & $\begin{array}{l}\text { SAPO- } \\
34\end{array}$ & $536-623$ & n.a. & n.a. & $0.1-0.5$ & n.a. & [179] \\
\hline
\end{tabular}

\section{Summary and Outlook}

Phenol acts as a harmful pollutant even in very low concentrations in water. Several methods have been developed to remove phenolic compounds from wastewater. Chemical adsorption and oxidation are the most common methods, but they still have some drawbacks including requiring higher energy consumption, maintenance (corrosion, sediment, and scale), high operating cost, and being unsustainable. As an alternative, ozone-based technology has been widely used to degrade organic pollutants because ozone has a high 
oxidizing ability. However, single ozonation exhibits very low efficiency, requires a large amount of ozone, low solubility in water, low reaction rate with organic compounds, and slow mineralization rate. Therefore, to overcome this problem, the involvement of a catalyst in the ozonation process is able to increase the degradation efficiency and reduce the use of ozone because there are reactive oxygen species formed from the decomposition of ozone involved in the reaction (i.e., hydroxyl radicals).

Catalytic ozonation consists of homogeneous catalytic ozonation and heterogeneous catalytic ozonation. Heterogeneous catalytic ozonation has the tremendous advantage of no secondary pollutant produced and an easier catalyst regeneration process than homogeneous catalytic ozonation. The degradation of phenol in solution using heterogeneous catalytic ozonation processes has been developed by many researchers. Of the various types of catalysts that have been developed, zeolite has the potential to be a promising catalyst in the catalytic ozonation process for the degradation of phenol waste. Zeolites have a large specific surface area, good thermal and chemical stability, and controllable hydrophilic/hydrophobic properties. Several parameters need to be reviewed to produce an ideal zeolite for the catalytic ozonation process of phenol waste removal, namely the Si/Al ratio, suitable pore size for adsorption of phenolic compounds, morphology, acidity level, and specific surface area. Furthermore, with a large surface area and short diffusion path length, nano-sized zeolites provide an active site that is more accessible to the pollutants so that the production of nano-sized zeolites is currently being developed.

There is still a lack of research with regard to the use of heterogeneous catalytic ozonation for phenol removals. Thus, to fulfill this research gap, the following strategies can be set for the future directions:

(i) Necessities of standardized performance evaluation.

In the literature, the choice of reactor type configuration is well reported to play a role in determining phenol removal efficiency. In fact, the number of parameters such as operating testing conditions $(\mathrm{pH}$, ozone concentration and flow rate, temperature, and pressure) and reactor configuration greatly affect the catalytic performance. As a result, we propose the necessity of a standardized performance evaluation technique so that the different catalysts developed for phenol removal can be appropriately compared.

(ii) Development of zeolite-based catalyst for phenol removal

Most research in heterogeneous catalytic ozonation for phenol removal has been to develop metal oxides-based catalysts. In fact, there are many types of zeolite-based catalysts as listed in Table 15 that can be further developed by tuning their physiochemical properties in order to exhibit excellent catalytic activity and stability towards phenol removal. Furthermore, developing an advanced synthetic method, that is, ultrafast synthesis using continuous flow to synthesis various types of zeolites in the order of seconds, provides great potential to facilitate the large-scale production of zeolite.

(iii) Elucidation of active sites in zeolite-based catalyst

Besides the mass production of zeolite, the understanding of fundamental reaction mechanisms, in particular, the catalytic active sites in heterogeneous catalytic ozonation are not fully understood. Thus, the utilization of in situ and operando characterizations will be beneficial to fully understand the active sites especially in zeolite-based catalysts for phenol removal.

(iv) Application of artificial intelligence (AI) for catalyst development

The development of an ideal catalyst for heterogeneous catalytic ozonation for phenol removal is still an important issue. An automatic machine learning framework based on artificial intelligence is advocated to allow the development of high-throughput catalysts with desired physiochemical properties for phenol removal in large-scale applications.

(v) Techno-economic evaluation of heterogeneous catalytic ozonation 
After finding the most optimum catalyst and suitable synthetic methods as well as reactor configuration process, techno-economic evaluation is necessary to be conducted in order to analyze the economic performance of the implementation of an industrial process. Ultimately, heterogeneous catalytic ozonation technology supported with the ease of the recovery and reuse of catalyst will lead to the creation of green, sustainable, environmentally friendly technology and will be the embodiment of the circular economy concept.

Author Contributions: Conceptualization, W.H.S., R.R.M., V.S. and D.S.; methodology, W.H.S., and A.S.P.; formal analysis, A.S.P.; investigation, A.S.P.; resources, W.H.S., R.R.M. and A.S.P.; writingoriginal draft preparation, W.H.S. and A.S.P.; writing—review and editing, W.H.S., A.S.P., V.S., R.R.M., A.A.E. and D.S.; visualization, A.S.P.; supervision, W.H.S., R.R.M. and D.S.; project administration, W.H.S.; funding acquisition, W.H.S., R.R.M. and D.S. All authors have read and agreed to the published version of the manuscript.

Funding: This research was funded by Riset Unggulan ITB 2021 (Grant No: 752A/IT1.C07.2/TA.00.2021) and Osaka Gas Foundation of International Cultural Exchange (OGFICE) 2020-2021 (Grant No: 251/IT1.B06/KU.02/2021).

Data Availability Statement: No new data were created or analyzed in this study. Data sharing is not applicable to this article.

Acknowledgments: The authors acknowledge the support from the Laboratory of Design Methodology, Process Design, and Control and Laboratory of Microbiology and Bioprocess Technology, Department of Chemical Engineering, Faculty of Industrial Technology, Institut Teknologi Bandung.

Conflicts of Interest: The authors declare no conflict of interest.

\section{References}

1. International Water Association (IWA). The Wastewater Report 2017 Reuse Opportunity; IWA: London, UK, 2018; pp. 1-20.

2. Calì, G.; Deiana, P.; Bassano, C.; Meloni, S.; Maggio, E.; Mascia, M.; Pettinau, A. Syngas Production, Clean-Up and Wastewater Management in a Demo-Scale Fixed-Bed Updraft Biomass Gasification Unit. Energies 2020, 13, 2594. [CrossRef]

3. Raza, W.; Lee, J.; Raza, N.; Luo, Y.; Kim, K.-H.; Yang, J. Removal of phenolic compounds from industrial waste water based on membrane-based technologies. J. Ind. Eng. Chem. 2019, 71, 1-18. [CrossRef]

4. Amin, N.A.S.; Akhtar, J.; Rai, H.K. Screening of combined zeolite-ozone system for phenol and COD removal. Chem. Eng. J. 2010, 158, 520-527. [CrossRef]

5. Ma, J.; Chen, Y.; Nie, J.; Ma, L.; Huang, Y.; Li, L.; Liu, Y.; Guo, Z. Pilot-scale study on catalytic ozonation of bio-treated dyeing and finishing wastewater using recycled waste iron shavings as a catalyst. Sci. Rep. 2018, 8, 7555. [CrossRef] [PubMed]

6. Dong, Y.; Wang, G.; Jiang, P.; Zhang, A.; Yue, L.; Zhang, X. Catalytic ozonation of phenol in aqueous solution by $\mathrm{Co}_{3} \mathrm{O}_{4}$ nanoparticles. Bull. Korean Chem. Soc. 2010, 31, 2830-2834. [CrossRef]

7. Qu, X.; Zheng, J.; Zhang, Y. Catalytic ozonation of phenolic wastewater with activated carbon fiber in a fluid bed reactor. J. Colloid Interface Sci. 2007, 309, 429-434. [CrossRef]

8. Kulkarni, S.J. Review on Research for Removal of Phenol from Wastewater. Int. J. Sci. Res. Publ. 2013, 3, 1-5.

9. Polat, H.; Molva, M.; Polat, M. Capacity and mechanism of phenol adsorption on lignite. Int. J. Miner. Process. 2006, 79, 264-273. [CrossRef]

10. Available online: https:/ / scopus.com/term/analyzer (accessed on 3 May 2021).

11. Ouyang, C.; Li, Y.; Li, J. The ZSM-5-Catalyzed Oxidation of Benzene to Phenol with $\mathrm{N}_{2} \mathrm{O}$ : Effect of Lewis Acid Sites. Catalysts 2019, 9, 44. [CrossRef]

12. Sobiesiak, M. Chemical Structure of Phenols and Its Consequence for Sorption Processes. In Phenolic Compounds-Natural Sources, Importance and Applications; IntechOpen: London, UK, 2017. [CrossRef]

13. Zhang, W.M.; Chen, J.L.; Pan, B.C.; Zhang, Q.X. Competitive and cooperative adsorption behaviors of phenol and aniline onto nonpolar macroreticular adsorbents. J. Environ. Sci. 2005, 17, 529-534.

14. Mohammadi, S.; Kargari, A.; Sanaeepur, H.; Abbassian, K.; Najafi, A.; Mofarrah, E. Phenol removal from industrial wastewaters: A short review. Desalination Water Treat. 2015, 53, 2215-2234. [CrossRef]

15. Villegas, L.G.C.; Mashhadi, N.; Chen, M.; Mukherjee, D.; Taylor, K.E.; Biswas, N. A Short Review of Techniques for Phenol Removal from Wastewater. Curr. Pollut. Rep. 2016, 2, 157-167. [CrossRef]

16. Health Protection Agency (HPA). HPA Compendium of Chemical Hazards: Phenol Toxicological Overview; Public Health England: London, UK, 2007; pp. 1-12.

17. Gami, A.A.; Shukor, M.Y.; Khalil, K.A.; Dahalan, F.A.; Khalid, A.; Ahmad, S.A. Phenol and its toxicity. J. Environ. Microbiol. Toxicol. 2014, $2,11-24$.

18. Raghu, D.; Hsieh, H.N. Considerations in disposal of phenolic waters. Int. J. Environ. Stud. 2007, 30, 277-285. [CrossRef] 
19. Marrot, B.; Moulin, P.; Roche, N. Biodegradation of high phenol concentration by activated sludge in an immersed membrane bioreactor. Biochem. Eng. J. 2006, 30, 174-183. [CrossRef]

20. Hussain, A.; Dubey, S.K.; Kumar, V. Kinetic study for aerobic treatment of phenolic wastewater. Water Resour. Ind. 2015, 11, 81-90. [CrossRef]

21. Wang, L.K.; Pereira, N.C.; Hung, Y.-T.; Shammas, N.K. Biological Treatment Processes. Anaerob. Waste-Wastewater Treat. Biogas Plants 2018, 1-22. [CrossRef]

22. Bevilaqua, J.V.; Cammarota, M.C.; Freire, D.M.G.; Sant'Anna, G.L., Jr. Phenol removal through combined biological and enzymatic treatments. Braz. J. Chem. Eng. 2002, 19, 151-158. [CrossRef]

23. Jackson, T.; Lynn, M.; Giarrusso, S.; Urich, S.; Holland, R.; Eldredge, M. Wastewater Technology Fact Sheet Package Plants; Environmental Protection Agency (EPA): Washington, DC, USA, 2000.

24. Busca, G.; Berardinelli, S.; Resini, C.; Arrighi, L. Technologies for the removal of phenol from fluid streams: A short review of recent developments. J. Hazard. Mater. 2008, 160, 265-288. [CrossRef] [PubMed]

25. Chemat, F.; Boutekedjiret, C. Extraction//Steam Distillation. In Reference Module in Chemistry, Molecular Sciences and Chemical Engineering; Elsevier: Amsterdam, The Netherlands, 2015.

26. Tumakaka, F.; Prikhodko, I.V.; Sadowski, G. Modeling of solid-liquid equilibria for systems with solid-complex phase formation. Fluid Phase Equilibria 2007, 260, 98-104. [CrossRef]

27. Janda, V.; Krijt, K. Recovery of phenols from water by continuous steam distillation-extraction. J. Chromatogr. A 1984, 283, 309-314. [CrossRef]

28. Norwitz, G.; Nataro, N.; Keliher, P.N. Study of the Steam Distillation of Phenolic Compounds Using Ultraviolet Spectrometry. Anal. Chem. 1986, 58, 639-641. [CrossRef]

29. Norwitz, G.; Nataro, N.; Keliher, P.N. Steam distillation of phenolic compounds in the presence of a large amount of sodium chloride. Microchem. J. 1987, 35, 240-243. [CrossRef]

30. Barták, P.; Frnková, P.; Čáp, L. Determination of phenols using simultaneous steam distillation-extraction. J. Chromatogr. A 2000, 867, 281-287. [CrossRef]

31. Ali, I. The quest for active carbon adsorbent substitutes: Inexpensive adsorbents for toxic metal ions removal from wastewater. Sep. Purif. Rev. 2010, 39, 95-171. [CrossRef]

32. Thang, P.Q.; Jitae, K.; Giang, B.L.; Viet, N.M.; Huong, P.T. Potential application of chicken manure biochar towards toxic phenol and 2,4-dinitrophenol in wastewaters. J. Environ. Manag. 2019, 251, 109556. [CrossRef]

33. Mukherjee, R.; De, S. Adsorptive removal of phenolic compounds using cellulose acetate phthalate-alumina nanoparticle mixed matrix membrane. J. Hazard. Mater. 2014, 265, 8-19. [CrossRef]

34. Rakic, V.; Rac, V.; Stosic, D. The investigation of phenol removal from aqueous solutions by zeolites as solid adsorbents. J. Hazard. Mater. 2010, 184, 477-484. [CrossRef]

35. Alshabib, M.; Onaizi, S.A. A review on phenolic wastewater remediation using homogeneous and heterogeneous enzymatic processes: Current status and potential challenges. Sep. Purif. Technol. 2019, 219, 186-207. [CrossRef]

36. Khalid, M.; Joly, G.; Renaud, A.; Magnoux, P. Removal of phenol from water by adsorption using zeolites. Ind. Eng. Chem. Res. 2004, 43, 5275-5280. [CrossRef]

37. Ma, Y.; Gao, N.; Chu, W.; Li, C. Removal of phenol by powdered activated carbon adsorption. Front. Environ. Sci. Eng. 2013, 7, 158-165. [CrossRef]

38. Mandal, A.; Das, S.K. Phenol adsorption from wastewater using clarified sludge from basic oxygen furnace. J. Environ. Chem. Eng. 2019, 7, 103259. [CrossRef]

39. Catizzone, E.; Sposato, C.; Romanelli, A.; Barisano, D.; Cornacchia, G.; Marsico, L.; Cozza, D.; Migliori, M. Purification of Wastewater from Biomass-Derived Syngas Scrubber Using Biochar and Activated Carbons. Int. J. Environ. Res. Public Health 2021, 18, 4247. [CrossRef]

40. Girish, C.R.; Murty, V.R. Adsorption of Phenol from Aqueous Solution Using Lantana camara, Forest Waste: Packed Bed Studies and Prediction of Breakthrough Curves. Environ. Process. 2015, 2, 773-796. [CrossRef]

41. Tri, N.L.M.; Thang, P.Q.; Van Tan, L.; Huong, P.T.; Kim, J.; Viet, N.M.; Phuong, N.M.; Al Tahtamouni, T.M. Removal of phenolic compounds from wastewaters by using synthesized Fe-nano zeolite. J. Water Process Eng. 2020, 33, 101070. [CrossRef]

42. Bin-Dahman, O.A.; Saleh, T.A. Synthesis of carbon nanotubes grafted with PEG and its efficiency for the removal of phenol from industrial wastewater. Environ. Nanotechnol. Monit. Manag. 2020, 13, 100286. [CrossRef]

43. Rahmanian, N.; Jafari, S.M.; Galanakis, C.M. Recovery and removal of phenolic compounds from olive mill wastewater. JAOCS J. Am. Oil Chem. Soc. 2014, 91, 1-18. [CrossRef]

44. Liu, J.; Xie, J.; Ren, Z.; Zhang, W. Solvent extraction of phenol with cumene from wastewater. Desalination Water Treat. 2013, 51, 3826-3831. [CrossRef]

45. Jiang, H.; Fang, Y.; Fu, Y.; Guo, Q.X. Studies on the extraction of phenol in wastewater. J. Hazard. Mater. 2003, 101, 179-190. [CrossRef]

46. Rao, N.N.; Singh, J.R.; Misra, R.; Nandy, T. Liquid-liquid extraction of phenol from simulated sebacic acid wastewater. J. Sci. Ind. Res. 2009, 68, 823-828.

47. Marco, E.D.; Savarese, M.; Paduano, A.; Sacchi, R. Characterization and fractionation of phenolic compounds extracted from olive oil mill wastewaters. Food Chem. 2007, 104, 858-867. [CrossRef] 
48. Bouaziz, M.; Bouallagui, Z.; Jemai, H.; Sayadi, S. Production of antioxidants from olive processing by-products. J. Environ. Agric. Food Chem. 2008, 8, 3231-3236.

49. Leonardis, A.D.; Macciola, V.; Lembo, G.; Aretini, A.; Nag, A. Food Chemistry Studies on oxidative stabilisation of lard by natural antioxidants recovered from olive-oil mill wastewater. Food Chem. 2007, 100, 998-1004. [CrossRef]

50. Yang, C.; Qian, Y.; Zhang, L.; Feng, J. Solvent extraction process development and on-site trial-plant for phenol removal from industrial coal-gasification wastewater. Chem. Eng. J. 2006, 117, 179-185. [CrossRef]

51. Yang, X.; Wang, B.; Luo, H.; Yan, S.; Dai, J.; Bai, Z. Efficient recovery of phenol from coal tar processing wastewater with tributylphosphane/diethyl carbonate/cyclohexane: Extraction cycle and mechanism study. Chem. Eng. Res. Des. 2020, 157, 104-113. [CrossRef]

52. Rubalcaba, A.; Suarez-Ojeda, M.E.; Stuber, F.; Fortuny, A.; Bengoa, C. Phenol wastewater remediation: Advanced oxidation processes coupled to a biological treatment. Water Sci. Technol. 2007, 55, 221-227. [CrossRef]

53. Chamberlin, A.N.S.; Griffin, A.E.; Pettit, G.A.; Sewage, S.; Wastes, I.; Jun, N.; Wastes, I.; Griffin, E. Chemical Oxidation of Phenolic Wastes with Chlorine. Water Environ. Fed. 2014, 24, 750-763.

54. Eisenhauer, H.R. Oxidation of phenolic wastes. Water Pollut. Control. Fed. 2015, 36, 1116-1128.

55. Chen, L.; Ma, J.; Li, X.; Zhang, J.; Fang, J.; Guan, Y.; Xie, P. Strong enhancement on Fenton oxidation by addition of hydroxylamine to accelerate the ferric and ferrous iron cycles. Environ. Sci. Technol. 2011, 45, 3925-3930. [CrossRef]

56. Wang, N.; Zheng, T.; Zhang, G.; Wang, P. A review on Fenton-like processes for organic wastewater treatment. J. Environ. Chem. Eng. 2016, 4, 762-787. [CrossRef]

57. Zhang, M.H.; Dong, H.; Zhao, L.; Wang, D.X.; Meng, D. A review on Fenton process for organic wastewater treatment based on optimization perspective. Sci. Total. Environ. 2019, 670, 110-121. [CrossRef]

58. Pigot, T.; Peings, V. Mechanism for the oxidation of phenol by sulfatoferrate (VI): Comparison with various oxidants. J. Environ. Manag. 2015, 157, 287-296. [CrossRef]

59. Zhang, J.; Sun, B.; Guan, X. Oxidative removal of bisphenol A by permanganate: Kinetics, pathways and influences of co-existing chemicals. Sep. Purif. Technol. 2013, 107, 48-53. [CrossRef]

60. Martínez-Huitle, C.A.; Ferro, S. Electrochemical oxidation of organic pollutants for the wastewater treatment: Direct and indirect processes. Chem. Soc. Rev. 2006, 35, 1324-1340. [CrossRef] [PubMed]

61. Tasic, Z.; Gupta, V.K.; Antonijevic, M.M. The mechanism and kinetics of degradation of phenolics in wastewaters using electrochemical oxidation. Int. J. Electrochem. Sci. 2014, 9, 3473-3490.

62. Saratale, R.G.; Hwang, K.J.; Song, J.Y.; Saratale, G.D.; Kim, D.S. Electrochemical oxidation of phenol for wastewater treatment using Ti/PbO2 electrode. J. Environ. Eng. 2016, 142, 04015064. [CrossRef]

63. Duan, X.; Ma, F.; Yuan, Z.; Jin, X.; Chang, L. Electrochemical degradation of phenol in aqueous solution using PbO2 anode. J. Taiwan Inst. Chem. Eng. 2013, 44, 95-102. [CrossRef]

64. Li, H.; Chen, Y.; Zhang, Y.; Han, W.; Sun, X.; Li, J.; Wang, L. Preparation of Ti/PbO2-Sn anodes for electrochemical degradation of phenol. J. Electroanal. Chem. 2013, 689, 193-200. [CrossRef]

65. Song, S.; Zhan, L.; He, Z.; Lin, L.; Tu, J.; Zhang, Z.; Chen, J.; Xu, L. Mechanism of the anodic oxidation of 4-chloro-3-methyl phenol in aqueous solution using $\mathrm{Ti} / \mathrm{SnO}_{2}-\mathrm{Sb} / \mathrm{PbO}_{2}$ electrodes. J. Hazard. Mater. 2010, 175, 614-621. [CrossRef]

66. Kumar, S.; Singh, S.; Srivastava, V.C. Electro-oxidation of nitrophenol by ruthenium oxide coated titanium electrode: Parametric, kinetic and mechanistic study. Chem. Eng. J. 2015, 263, 135-143. [CrossRef]

67. Kong, J.T.; Shi, S.Y.; Zhu, X.P.; Ni, J.R. Effect of Sb dopant amount on the structure and electrocatalytic capability of Ti/Sb-SnO2 electrodes in the oxidation of 4-chlorophenol. J. Environ. Sci. 2007, 19, 1380-1386. [CrossRef]

68. Yang, X.; Zou, R.; Huo, F.; Cai, D.; Xiao, D. Preparation and characterization of Ti/SnO2-Sb2O3-Nb2O5/PbO2 thin film as electrode material for the degradation of phenol. J. Hazard. Mater. 2009, 164, 367-373. [CrossRef]

69. Wang, Y.; Shen, Z.; Li, Y.; Niu, J. Electrochemical properties of the erbium-chitosan-fluorine-modified PbO2 electrode for the degradation of 2,4-dichlorophenol in aqueous solution. Chemosphere 2010, 79, 987-996. [CrossRef] [PubMed]

70. Zhao, T.; Lu, J.; Hu, C.; Zhu, C.; Zhao, J.; Dong, W. Electrochemical degradation of 4, 4'-(propane-2, 2-diyl) diphenol in water with $\mathrm{CeO} 2 / \beta-\mathrm{PbO} 2 / \mathrm{Ti}$ electrode. Int. J. Electrochem. Sci. 2014, 9, 2354-2366.

71. Bolong, N.; Ismail, A.F.; Salim, M.R.; Matsuura, T. A review of the effects of emerging contaminants in wastewater and options for their removal. Desalination 2009, 239, 229-246. [CrossRef]

72. Ren, L.F.; Chen, R.; Zhang, X.; Shao, J.; He, Y. Phenol biodegradation and microbial community dynamics in extractive membrane bioreactor (EMBR) for phenol-laden saline wastewater. Bioresour. Technol. 2017, 244, 1121-1128. [CrossRef] [PubMed]

73. Slater, C.S.; Schurmann, T.; MacMillian, J.; Zimarowski, A. Separation of diacteone alcohol-water mixtures by membrane pervaporation. Sep. Sci. Technol. 2006, 41, 2733-2753. [CrossRef]

74. Li, J.; Wu, J.; Sun, H.; Cheng, F.; Liu, Y. Advanced treatment of biologically treated coking wastewater by membrane distillation coupled with pre-coagulation. Desalination 2016, 380, 43-51. [CrossRef]

75. Ng, Y.S.; Jayakumar, N.S.; Hashim, M.A. Performance evaluation of organic emulsion liquid membrane on phenol removal. J. Hazard. Mater. 2010, 184, 255-260. [CrossRef]

76. Boonnorat, J.; Chiemchaisri, C.; Chiemchaisri, W.; Yamamoto, K. Removals of phenolic compounds and phthalic acid esters in landfill leachate by microbial sludge of two-stage membrane bioreactor. J. Hazard. Mater. 2014, 277, 93-101. [CrossRef] 
77. Ghaemi, N.; Madaeni, S.S.; Alizadeh, A.; Daraei, P.; Badieh, M.M.S.; Falsafi, M.; Vatanpour, V. Fabrication and modification of polysulfone nanofiltration membrane using organic acids: Morphology, characterization and performance in removal of xenobiotics. Sep. Purif. Technol. 2012, 96, 214-228. [CrossRef]

78. Li, Y.; Wei, J.; Wang, C.; Wang, W. Comparison of phenol removal in synthetic wastewater by NF or RO membranes. Desalination Water Treat. 2010, 22, 211-219. [CrossRef]

79. Praveen, P.; Loh, K.C. Osmotic membrane bioreactor for phenol biodegradation under continuous operation. J. Hazard. Mater. 2016, 305, 115-122. [CrossRef] [PubMed]

80. Casademont, P.; García-Jarana, M.B.; Sánchez-Oneto, J.; Portela, J.R.; de la Ossa, E.J.M. Supercritical water gasification: A patents review. Reviews in Chemical Engineering 2017, 33, 237-261. [CrossRef]

81. Yakaboylu, O.; Harinck, J.; Smit, K.G.; De Jong, W. Supercritical Water Gasification of Biomass: A Literature and Technology Overview. Energies 2015, 8, 859-894. [CrossRef]

82. DiLeo, G.J.; Neff, M.E.; Kim, S.; Savage, P.E. Supercritical Water Gasification of Phenol and Glycine as Models for Plant and Protein Biomass. Energy Fuels 2008, 22, 871-877. [CrossRef]

83. Castello, D.; Kruse, A.; Fiori, L. Supercritical water gasification of glucose/phenol mixtures as model compounds for lignocellulosic biomass. Chem. Eng. Trans. 2014, 37, 193-198.

84. Guan, Q.; Wei, C.; Shi, H.; Wu, C.; Chai, X.-S. Partial oxidative gasification of phenol for hydrogen in supercritical water. Appl. Energy 2011, 88, 2612-2616. [CrossRef]

85. Kruse, A. Supercritical water gasification. Biofuels Bioprod. Biorefining 2008, 2, 415-437. [CrossRef]

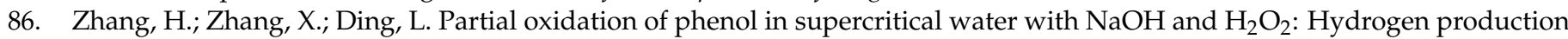
and polymer formation. Sci. Total. Environ. 2020, 722, 137985. [CrossRef]

87. Xu, D.; Wang, S.; Guo, Y.; Tang, X.; Gong, Y.; Ma, H. Catalyzed Partial Oxidative Gasification of Phenol in Supercritical Water. Ind. Eng. Chem. Res. 2011, 50, 4301-4307. [CrossRef]

88. Forero, J.E.; Duque, J.J.; Rios, F.; Díaz, J. Ozone for phenol treatment in industrial wastewater. CT F Cienc. Tecnol. Y Futuro 2001, 2, 17-26.

89. Wang, J.; Chen, H. Catalytic ozonation for water and wastewater treatment: Recent advances and perspective. Sci. Total. Environ. 2020, 704, 135249. [CrossRef] [PubMed]

90. Von Sonntag, C.; von Gunten, U. Chemistry of Ozone in Water and Wastewater Treatment: From Basic Principles to Applications; IWA Publishing: London, UK, 2012.

91. Kasprzyk-Hordern, B.; Ziółek, M.; Nawrocki, J. Catalytic ozonation and methods of enhancing molecular ozone reactions in water treatment. Appl. Catal. B Environ. 2003, 46, 639-669. [CrossRef]

92. Wei, C.; Zhang, F.; Hu, Y.; Feng, C.; Wu, H. Ozonation in water treatment: The generation, basic properties of ozone and its practical application. Rev. Chem. Eng. 2017, 33, 49-89. [CrossRef]

93. Hoigné, J. Chemistry of Aqueous Ozone and Transformation of Pollutants by Ozonation and Advanced Oxidation Processes. Handb. Environ. Chem. 1998, 5, 83-141. [CrossRef]

94. Sano, N.; Yamamoto, T.; Yamamoto, D.; Kim, S.I.; Eiad-Ua, A.; Shinomiya, H.; Nakaiwa, M. Degradation of aqueous phenol by simultaneous use of ozone with silica-gel and zeolite. Chem. Eng. Process. Process Intensif. 2007, 46, 513-519. [CrossRef]

95. Haag, W.R.; Holgné, J. Ozonation of Bromide-Containing Waters: Kinetics of Formation of Hypobromous Acid and Brómate. Environ. Sci. Technol. 1983, 17, 261-267. [CrossRef]

96. Turhan, K.; Uzman, S. Removal of phenol from water using ozone. Desalination 2008, 229, 257-263. [CrossRef]

97. Wahyudi, D.P.; Ghaisani, S.V.; Bismo, S. Degradation of phenol and 2,4-dichlorophenol wastewater by ozonation in multi-injection bubble column reactor. J. Phys. Conf. Ser. 2019, 1349, 012074. [CrossRef]

98. Zeng, Z.; Zou, H.; Li, X.; Arowo, M.; Sun, B.; Chen, J.; Chu, G.; Shao, L. Degradation of phenol by ozone in the presence of Fenton reagent in a rotating packed bed. Chem. Eng. J. 2013, 229, 404-411. [CrossRef]

99. Karamah, E.F.; Leonita, S.; Bismo, S. Phenols removal using ozonation-adsorption with granular activated carbon (GAC) in rotating packed bed reactor. IOP Conf. Ser. Mater. Sci. Eng. 2018, 299, 012094. [CrossRef]

100. Cheng, W.; Quan, X.; Li, R.; Wu, J.; Zhao, Q. Ozonation of Phenol-Containing Wastewater Using O3/Ca(OH)2 System in a Micro Bubble Gas-Liquid Reactor. Ozone Sci. Eng. 2018, 40, 173-182. [CrossRef]

101. Suzuki, H.; Araki, S.; Yamamoto, H. Evaluation of advanced oxidation processes (AOP) using $\mathrm{O}_{3}, \mathrm{UV}$, and $\mathrm{TiO}_{2}$ for the degradation of phenol in water. J. Water Process Eng. 2015, 7, 54-60. [CrossRef]

102. Drijvers, D.; Langenhove, H.V.A.N.; Beckers, M. Decomposition of phenol and trichloroethylene by the ultrasound $/ \mathrm{H}_{2} \mathrm{O}_{2} / \mathrm{CuO}$ process. Water Res. 1999, 33, 1187-1194. [CrossRef]

103. Kidak, R.; Ince, N.H. Catalysis of advanced oxidation reactions by ultrasound: A case study with phenol. J. Hazard. Mater. 2007, 146, 630-635. [CrossRef]

104. Entezari, M.H.; Christian, P. Sonochemical degradation of phenol in water: A comparison of classical equipment with a new cylindrical reactor. Ultrason. Sonochem. 2003, 10, 103-108. [CrossRef]

105. Primo, O.; Rivero, J.; Ortiz, I.; Irabien, A. Mathematical modelling of phenol photooxidation: Kinetics of the process toxicity. Chem. Eng. J. 2007, 134, 23-28. [CrossRef]

106. Paucar, N.E.; Kim, I.; Tanaka, H.; Sato, C. Effect of O3 Dose on the O3/UV Treatment Process for the Removal of Pharmaceuticals and Personal Care Products in Secondary Effluent. ChemEngineering 2019, 3, 53. [CrossRef] 
107. Saputera, W.H.; Scott, J.; Tahini, H.; Low, G.K.C.; Tan, X.; Smith, S.; Wang, D.-W.; Amal, R. Light, Catalyst, Activation: Boosting Catalytic Oxygen Activation Using a Light Pretreatment Approach. ACS Catal. 2017, 7, 3644-3653. [CrossRef]

108. Saputera, W.H.; Tahini, H.A.; Lovell, E.C.; Tan, T.H.; Rawal, A.; Aguey-Zinsou, K.-F.; Friedmann, D.; Smith, S.C.; Amal, R.; Scott, J. Cooperative defect-enriched $\mathrm{SiO} 2$ for oxygen activation and organic dehydrogenation. J. Catal. 2019, 376, 168-179. [CrossRef]

109. Saputera, W.H.; Tahini, H.A.; Sabsabi, M.; Tan, T.H.; Bedford, N.M.; Lovell, E.; Cui, Y.; Hart, J.N.; Friedmann, D.; Smith, S.C.; et al. Light-Induced Synergistic Multidefect Sites on TiO2/SiO2 Composites for Catalytic Dehydrogenation. ACS Catal. 2019, 9, 2674-2684. [CrossRef]

110. Hamdy, M.S.; Saputera, W.H.; Groenen, E.J.; Mul, G. A novel TiO2 composite for photocatalytic wastewater treatment. J. Catal. 2014, 310, 75-83. [CrossRef]

111. Saputera, W.H.; Mul, G.; Hamdy, M.S. Ti3+-containing titania: Synthesis tactics and photocatalytic performance. Catal. Today 2015, 246, 60-66. [CrossRef]

112. Oller, I.; Malato, S.; Sánchez-Pérez, J.A. Combination of Advanced Oxidation Processes and biological treatments for wastewater decontamination-A review. Sci. Total. Environ. 2011, 409, 4141-4166. [CrossRef] [PubMed]

113. Yang, L.; Sheng, M.; Li, Y.; Xue, W.; Li, K.; Cao, G. A hybrid process of Fe-based catalytic ozonation and biodegradation for the treatment of industrial wastewater reverse osmosis concentrate. Chemosphere 2020, 238, 124639. [CrossRef] [PubMed]

114. Beltrán, F.J.; Rivas, J.; Álvarez, P.; Montero-de-Espinosa, R. Kinetics of heterogeneous catalytic ozone decomposition in water on an activated carbon. Ozone Sci. Eng. 2002, 24, 227-237. [CrossRef]

115. Ni, C.-H.; Chen, J.-N.; Yang, P.-Y. Catalytic ozonation of 2-dichlorophenol by metallic ions. Water Sci. Technol. 2003, 47, 77-82. [CrossRef]

116. Matheswaran, M.; Balaji, S.; Chung, S.J.; Moon, I.S. Studies on cerium oxidation in catalytic ozonation process: A novel approach for organic mineralization. Catal. Commun. 2007, 8, 1497-1501. [CrossRef]

117. Guo, Y.; Yang, L.; Cheng, X.; Wang, X. The Application and Reaction Mechanism of Catalytic Ozonation in Water Treatment. Environ. Anal. Toxicol. 2016, 2, 150. [CrossRef]

118. Wang, B.; Zhang, H.; Wang, F.; Xiong, X.; Tian, K.; Sun, Y.; Yu, T. Application of heterogeneous catalytic ozonation for Refractory Organics in Wastewater. Catalysts 2019, 9, 241. [CrossRef]

119. Malaika, A.; Morawa Eblagon, K.; Soares, O.S.G.P.; Pereira, M.F.R.; Figueiredo, J.L. The impact of surface chemistry of carbon xerogels on their performance in phenol removal from wastewaters via combined adsorption-catalytic process. Appl. Surf. Sci. 2020, 511, 145467. [CrossRef]

120. Ni, C.H.; Chen, J.N. Heterogeneous catalytic ozonation of 2-chlorophenol aqueous solution with alumina as a catalyst. Water Sci. Technol. J. Int. Assoc. Water Pollut. Res. 2001, 43, 213-220. [CrossRef]

121. Kruanak, K.; Jarusutthirak, C. Degradation of 2,4,6-trichlorophenol in synthetic wastewater by catalytic ozonation using alumina supported nickel oxides. J. Environ. Chem. Eng. 2019, 7, 102825. [CrossRef]

122. Wei, X.; Shao, S.; Ding, X.; Jiao, W.; Liu, Y. Degradation of phenol with heterogeneous catalytic ozonation enhanced by high gravity technology. J. Clean. Prod. 2020, 248, 119179. [CrossRef]

123. Xiong, W.; Cui, W.; Li, R.; Feng, C.; Liu, Y.; Ma, N.; Deng, J.; Xing, L.; Gao, Y.; Chen, N. Mineralization of phenol by ozone combined with activated carbon: Performance and mechanism under different pH levels. Environ. Sci. Ecotechnol. 2020, 1, 100005. [CrossRef]

124. Li, X.; Chen, W.; Ma, L.; Wang, H.; Fan, J. Industrial wastewater advanced treatment via catalytic ozonation with an Fe-based catalyst. Chemosphere 2018, 195, 336-343. [CrossRef] [PubMed]

125. Nawaz, F.; Xie, Y.; Xiao, J.; Cao, H.; Ghazi, Z.A.; Guo, Z.; Chen, Y. The influence of the substituent on the phenol oxidation rate and reactive species in cubic MnO2 catalytic ozonation. Catal. Sci. Technol. 2016, 6, 7875-7884. [CrossRef]

126. Hayek, N.A.; Legube, B.; Doré, M. Ozonation catalytique (Fe III/A12O3) Du phénol et de ses produits d'ozonation. Environ. Technol. Lett. 2008, 10, 415-426. [CrossRef]

127. Moussavi, G.; Khavanin, A.; Alizadeh, R. The investigation of catalytic ozonation and integrated catalytic ozonation/biological processes for the removal of phenol from saline wastewaters. J. Hazard. Mater. 2009, 171, 175-181. [CrossRef]

128. Zhang, J.; Zhuang, T.; Liu, S.; Zhang, G.C.; Huo, K. Catalytic ozonation of phenol enhanced by mesoporous MnO2 prepared through nanocasting method with SBA-15 as template. J. Environ. Chem. Eng. 2020, 8, 103967. [CrossRef]

129. Nawaz, F.; Xie, Y.; Xiao, J.; Cao, H.; Li, Y.; Zhang, D. Insights into the mechanism of phenolic mixture degradation by catalytic ozonation with a mesoporous Fe3O4/MnO2 composite. RSC Adv. 2016, 6, 29674-29684. [CrossRef]

130. Cooper, C.; Burch, R. Mesoporous materials for water treatment processes. Water Res. 1999, 33, 3689-3694. [CrossRef]

131. Jafari, S.; Derakhshankhah, H.; Alaei, L.; Fattahi, A.; Varnamkhasti, B.S.; Saboury, A.A. Mesoporous silica nanoparticles for therapeutic/diagnostic applications. Biomed. Pharmacother. 2019, 109, 1100-1111. [CrossRef] [PubMed]

132. Mgbemere, H.E.; Ekpa, I.C.; Lawal, G.I. Zeolite Synthesis, Characterisation and Application Areas: A Review. Int. Res. J. Environ. Sci. 2017, 6, 45-59. [CrossRef]

133. Kolosov, P.; Peyot, M.L.; Yargeau, V. Novel materials for catalytic ozonation of wastewater for disinfection and removal of micropollutants. Sci. Total. Environ. 2018, 644, 1207-1218. [CrossRef] [PubMed]

134. Jelfs, K.E.; Slater, B.; Lewis, D.W.; Willock, D.J. The role of organic templates in controlling zeolite crystal morphology. Stud. Surf. Sci. Catal. 2007, 170, 1685-1692. [CrossRef] 
135. Kitada, Y.; Kawahata, H.; Suzuki, A.; Oomori, T. Distribution of pesticides and bisphenol A in sediments collected from rivers adjacent to coral reefs. Chemosphere 2008, 71, 2082-2090. [CrossRef] [PubMed]

136. Dong, Y.; Yang, H.; He, K.; Wu, X.; Zhang, A. Catalytic activity and stability of Y zeolite for phenol degradation in the presence of ozone. Appl. Catal. B Environ. 2008, 82, 163-168. [CrossRef]

137. Ikhlaq, A.; Brown, D.R.; Kasprzyk-Hordern, B. Catalytic ozonation for the removal of organic contaminants in water on ZSM-5 zeolites. Appl. Catal. B Environ. 2014, 154-155, 110-122. [CrossRef]

138. Fujita, H.; Izumi, J.; Sagehashi, M.; Fujii, T.; Sakoda, A. Adsorption and decomposition of water-dissolved ozone on high silica zeolites. Water Res. 2004, 38, 159-165. [CrossRef]

139. Bu, X.; Feng, P.; Gier, T.E.; Zhao, D.; Stucky, G.D. Hydrothermal Synthesis and Structural Characterization of Zeolite-like Structures Based on Gallium and Aluminum Germanates. J. Am. Chem. Soc. 1998, 120, 13389-13397. [CrossRef]

140. Lobo, R.F.; Davis, M.E. CIT-1: A New Molecular Sieve with Intersecting Pores Bounded by 10- and 12-Rings. J. Am. Chem. Soc. 1995, 117, 3766-3779. [CrossRef]

141. Schmidt, J.E.; Xie, D.; Reab, T.; Davis, M.E. Chemical Science bounded by 8 and 10-membered rings. Chem. Sci. 2015, 6, 1728-1734. [CrossRef]

142. Rane, S.J.; Satyanarayana, C.V.V.; Chakrabarty, D.K. Shape selective catalysis by ZSM-35 zeolites: Disproportionation of ethylbenzene and isomerization of m-xylene. Appl. Catal. 1991, 69, 177-186. [CrossRef]

143. Rouleau, N.; Paillaud, L.; Frangais, I.; Navarre, C.R. Recent developments in the use of hexamethonium salts as structure directing agents in zeolite synthesis. Surf. Sci. Catal. 2004, 154, 283-288.

144. Corma, A.; Diaz-cabanas, M.J.; Jorda, J.L.; Rey, F.; Sastre, G.; Strohmaier, K.G. A Zeolitic Structure (ITQ-34) with Connected 9- and 10-Ring Channels Obtained with Phosphonium Cations as Structure Directing Agents. J. Am. Chem. Soc. 2008, 13, 16482-16483. [CrossRef] [PubMed]

145. Verheyen, E.; Joos, L.; Havenbergh, K.V.; Breynaert, E.; Kasian, N.; Gobechiya, E.; Houthoofd, K.; Martineau, C.; Hinterstein, M.; Taulelle, F.; et al. Design of zeolite by inverse sigma transformation. Nat. Mater. 2012, 11, 1059-1064. [CrossRef]

146. Reddy, S.; Kumar, R. Crystallization kinetics of a new titanium silicate with MEL structure (TS-2). Zeolites 1992, 12, 95-100. [CrossRef]

147. Kokotailo, G.T.; Lawton, S.L.; Olson, D.H.; Meier, W.M. Structure of synthetic zeolite ZSM-5. Nature 1978, 272, 437-438. [CrossRef]

148. Schlenker, J.L.; Higgins, J.B.; Valyocsik, E.W. The framework topology of ZSM-57: A new synthetic zeolite. Zeolites 1990, 10, 293-296. [CrossRef]

149. Dorset, D.L.; Weston, S.C.; Dhingra, S.S. Crystal Structure of Zeolite MCM-68: A New Three-Dimensional Framework with Large Pores. J. Phys. Chem. B 2006, 18, 2045-2050. [CrossRef]

150. Rohrman, A.C.; LaPierre, J.R.B.; Schlenker, J.L.; Wood, J.D.; Valyocsik, E.W.; Higgins, J.B.; Rohrbaugh, W.J. The framework topology of ZSM-23: A high silica zeolite. Zeolites 1985, 5, 352-354. [CrossRef]

151. Shannon, M.D.; Casti, J.L.; Cox, P.A.; Andrews, S.J. Structure ofthe two-dimensional medium-pore high-silica zeolite NU-87. Nature 1991, 353, 417-420. [CrossRef]

152. Lee, J.K.; Turrina, A.; Zhu, L.; Seo, S.; Zhang, D.; Cox, P.A.; Wright, P.A.; Qiu, S.; Hong, S.B. An Aluminophosphate Molecular Sieve with 36 Crystallographically Distinct Tetrahedral Sites. Angew. Chem. Int. Ed. 2014, 126, 7610-7613. [CrossRef]

153. Su, J.; Wang, Y.; Wang, Z.; Lin, J. PKU-9: An Aluminogermanate with a New Three-Dimensional Zeolite Framework Constructed from CGS Layers and Spiro -5 Units. J. Am. Chem. Soc. 2009, 131, 6080-6081. [CrossRef]

154. Jo, D.; Park, G.T.; Shin, J.; Hong, S.B. A Zeolite Family Nonjointly Built from the 1,3-Stellated Cubic Building Unit. Angezw. Chem. Int. Ed. 2007, 57, 2199-2203. [CrossRef] [PubMed]

155. Xie, D.; Mccusker, L.B.; Baerlocher, C. Structure of the Borosilicate Zeolite Catalyst SSZ-82 Solved Using 2D-XPD Charge Flipping. J. Am. Chem. Soc. 2011, 133, 20604-20610. [CrossRef]

156. Rings, E.-M.; Wagner, P.; Zones, S.I.; Davis, M.E.; Medrud, R.C. SSZ-35 and SSZ-44: Two Related Zeolites. Angew. Chem. Int. Ed. 1999, 35, 1269-1272.

157. Burton, A.; Elomari, S.; Medrud, R.C.; Chan, I.Y.; Chen, C.-Y.; Bull, L.M.; Vittoratos, E.S. The Synthesis, Characterization, and Structure Solution of SSZ-58: A Novel Two-Dimensional 10-Ring Pore Zeolite with Previously Unseen Double 5-Ring Subunits. J. Am. Chem. Soc. 2003, 125, 1633-1642. [CrossRef] [PubMed]

158. Elomari, S.; Burton, A.; Medrud, R.C.; Grosse-kunstleve, R. Microporous and Mesoporous Materials The synthesis, characterization, and structure solution of SSZ-56: An extreme example of isomer specificity in the structure direction of zeolites. Microporous Mesoporous Mater. 2009, 118, 325-333. [CrossRef]

159. Hong, S.B.; Lear, E.G.; Wright, P.A.; Zhou, W.; Cox, P.A.; Shin, C.-H.; Park, J.-H.; Nam, I.-S. Synthesis, Structure Solution, Characterization, and Catalytic Properties of TNU-10: A High-Silica Zeolite with the STI Topology. J. Am. Chem. Soc. 2004, 126, 5817-5826. [CrossRef] [PubMed]

160. Tang, L.; Shi, L.E.I.; Bonneau, C.; Sun, J.; Yue, H.; Ojuva, A.; Mink, J.; Lee, B.-L.; Kritikos, M.; Bell, R.G.; et al. A zeolite family with chiral and achiral structures built from the same building layer. Nat. Mater. 2008, 7, 381-385. [CrossRef] [PubMed]

161. Baerlocher, C.; Xie, D.A.N.; Cusker, L.B.M.C.; Hwang, S.-J.; Chan, I.Y.; Ong, K.; Burton, A.W.; Zones, S.I. Ordered silicon vacancies in the framework structure of the zeolite catalyst SSZ-74. Nat. Mater. 2008, 7, 631-635. [CrossRef] [PubMed]

162. Barri, S.A.I.; Smith, G.W.; White, D.; Young, D. Structure of Theta-1, the first unidimensional medium-pore high-silica zeolite. Nature 1984, 312, 533-534. [CrossRef] 
163. Lorgouilloux, Y.; Dodin, M.; Mugnaioli, E.; Marichal, C. IM-17: A new zeolitic material, synthesis and structure elucidation from electron diffraction ADT data and Rietveld analysis. R. Soc. Chem. 2014, 4, 19440-19449. [CrossRef]

164. Huang, M.; Kaliaguine, S.; Auroux, A. Lewis basic and Lewis acidic sites in zeolites. In Studies in Surface Science and Catalysis; Elsevier: Amsterdam, The Netherlands, 1995; pp. 311-318.

165. Valdés, H.; Tardón, R.F.; Zaror, C.A. Role of surface hydroxyl groups of acid-treated natural zeolite on the heterogeneous catalytic ozonation of methylene blue contaminated waters. Chem. Eng. J. 2012, 211-212, 388-395. [CrossRef]

166. Liu, Y.; Han, S.; Jiang, N.; Guan, D.; Chen, S.; Wu, Y.; Yang, Y. Microporous and Mesoporous Materials Rapid green synthesis of ZSM-5 zeolite from leached illite clay. Microporous Mesoporous Mater. 2019, 280, 324-330. [CrossRef]

167. Yin, Z.H.; Chen, Y.; Wang, Z.W.; Xing, Y.; Tian, X.J.; Yu, Q.; Meng, C.G. Synthesis of ZSM-5 Zeolite without Organic Template. Adv. Mater. Res. 2015, 1096, 176-180. [CrossRef]

168. Louis, B.; Kiwi-Minsker, L. Synthesis of ZSM-5 zeolite in fluoride media: An innovative approach to tailor both crystal size and acidity. Microporous Mesoporous Mater. 2004, 74, 171-178. [CrossRef]

169. Mackinnon, I.D.R.; Millar, G.J.; Stolz, W. Low temperature synthesis of zeolite N from kaolinites and montmorillonites. Appl. Clay Sci. 2010, 48, 622-630. [CrossRef]

170. Liu, Z.; Okabe, K.; Anand, C.; Yonezawa, Y.; Zhu, J.; Yamada, H.; Endo, A.; Yanaba, Y.; Yoshikawa, T.; Ohara, K.; et al. Continuous flow synthesis of ZSM-5 zeolite on the order of seconds. Proc. Natl. Acad. Sci. USA 2016, 113, 14267-14271. [CrossRef] [PubMed]

171. Manafi, S.S.A.; Branch, S.; Joughehdoust, S. Production of zeolite using different methods IIZC-08-277 Production of zeolite using different methods. In Proceedings of the Iran International Zeolite Conference (IIZC'08), Tehran, Iran, 29 April-1 May 2008.

172. Steen, E.V.; Callanan, L.H.; Division, C. Synthesis and characterization of the nanocrystalline zeolite ZSM-35. Surf. Sci. Catal. 2004, 154, 189-194.

173. Asgari, G.; Rahmani, A.R.; Askari, F.B.; Godini, K. Catalytic ozonation of phenol using copper coated pumice and zeolite as catalysts. J. Res. Health Sci. 2012, 12, 93-97. [PubMed]

174. Qi, R.; Fu, T.; Wan, W.; Li, Z. Pore fabrication of nano-ZSM-5 zeolite by internal desilication and its in fl uence on the methanol to hydrocarbon reaction. Fuel Process. Technol. 2017, 155, 191-199. [CrossRef]

175. Feng, X.; Zhang, P.; Fang, Y.; Charusiri, W.; Yao, J.; Gao, X.; Wei, Q.; Reubroycharoen, P.; Vitidsant, T.; Yoneyama, Y.; et al. Designing a hierarchical nanosheet ZSM-35 zeolite to realize more efficient ethanol synthesis from dimethyl ether and syngas. Catal. Today 2020, 343, 206-214. [CrossRef]

176. Ou, X.; Xu, S.; Warnett, J.M.; Holmes, S.M.; Zaheer, A.; Garforth, A.A.; Williams, M.A.; Jiao, Y.; Fan, X. Creating hierarchies promptly: Microwave-accelerated synthesis of ZSM-5 zeolites on macrocellular silicon carbide (SiC) foams. Chem. Eng. J. 2017, 312, 1-9. [CrossRef]

177. Wei, P.; Zhu, X.; Wang, Y.; Chu, W.; Xie, S.; Yang, Z.; Liu, X.; Li, X.; Xu, L. Rapid synthesis of ferrierite zeolite through microwave assisted organic template free route. Microporous Mesoporous Mater. 2019, 279, 220-227. [CrossRef]

178. Zhu, J.; Liu, Z.; Sukenaga, S.; Ando, M.; Shibata, H.; Okubo, T.; Wakihara, T. Ultrafast synthesis of *BEA zeolite without the aid of aging pretreatment. Microporous Mesoporous Mater. 2018, 268, 1-8. [CrossRef]

179. Sun, Q.; Wang, N.; Guo, G.; Yu, J. Ultrafast synthesis of nano-sized zeolite SAPO-34 with excellent MTO catalytic performance. Chem. Commun. 2015, 51, 16397-16400. [CrossRef] 